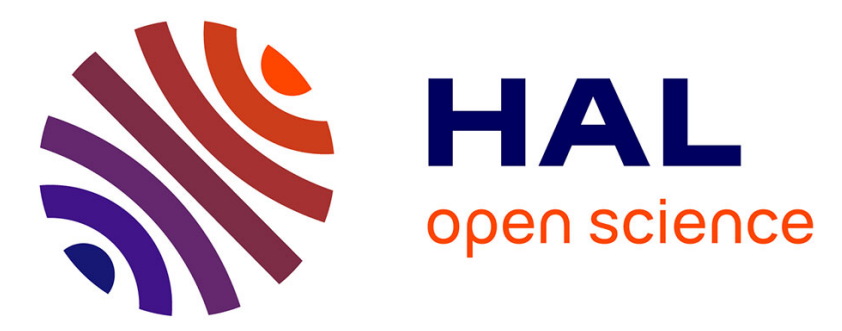

\title{
Fiscal Capacity and Dualism in Colonial States: The French Empire 1830-1962
}

Denis Cogneau, Yannick Dupraz, Sandrine Mesplé-Somps

\section{To cite this version:}

Denis Cogneau, Yannick Dupraz, Sandrine Mesplé-Somps. Fiscal Capacity and Dualism in Colonial States: The French Empire 1830-1962. 2019. halshs-01818700v3

\section{HAL Id: halshs-01818700 \\ https://hal.science/halshs-01818700v3}

Preprint submitted on 24 Sep 2019 (v3), last revised 17 Nov 2020 (v4)

HAL is a multi-disciplinary open access archive for the deposit and dissemination of scientific research documents, whether they are published or not. The documents may come from teaching and research institutions in France or abroad, or from public or private research centers.
L'archive ouverte pluridisciplinaire HAL, est destinée au dépôt et à la diffusion de documents scientifiques de niveau recherche, publiés ou non, émanant des établissements d'enseignement et de recherche français ou étrangers, des laboratoires publics ou privés. 


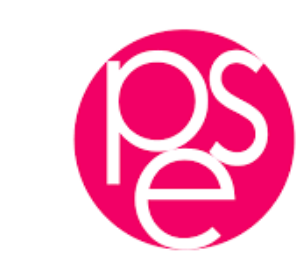

PARISSCHOOLOFECONOMICS
ECOLED'ECONOMIE DE PARIS

WORKING PAPER N ${ }^{\circ} 2018-27$

Fiscal Capacity and Dualism in Colonial States:

The French Empire 1830-1962

Denis Cogneau

Yannick Dupraz

Sandrine Mesplé-Somps

JEL Codes:

Keywords: 


\title{
Fiscal Capacity and Dualism in Colonial States: The French Empire 1830-1962
}

\author{
Denis Cogneau ${ }^{1}$, Yannick Dupraz ${ }^{2}$ and Sandrine Mesplé-Somps ${ }^{3}$
}

\begin{abstract}
To provide comparative evidence on the states of the second French colonial empire (1830-1962), we build a new database, unprecedented in detail, and in geographical and historical scope. The data reveal that the French colonies had high extractive efficiency, but low productive efficiency. Colonial states taxed extensively, adapting fiscal tools to varying economic contexts and historical conditions, but they achieved little because public expenditures entailed high wage costs for expatriate civil servants, and exhibited a bias toward needs of French settlers and capitalists. Socioeconomic and political dualism emerges as a common colonial inheritance.
\end{abstract}

\footnotetext{
Ackowledgements: This work was made possible thanks to the funding of the French National Agency for Research (ANR), Project Afristory ANR-11-BSHS1-006. Supplementary funding from Cepremap was also very useful. We are grateful to Cédric Chambru, Anna Peixoto-Charles, Ariane Salem, Manon Falquerho, Cyprien Batut, Quynh Hoang and Björn Nilsson for excellent research assistance. We thank Elise Huillery for participation in the kickoff of the collection effort. Jean-Pascal Bassino was kind enough to give us access to his data on Indochina. We thank Gareth Austin, Guillaume Daudin, James Fenske, Ewout Frankema, Leigh Gardner, Bishnupriya Gupta, Pierre-Cyrille Hautcoeur, Elise Huillery, Sylvie Lambert, Peter Lindert, Eric Monnet, Alexander Moradi and Thomas Piketty for their helpful comments, as well as conference and seminar participants at WEHC Kyoto (2015) and Boston (2018), and at: Universities Bocconi, Bordeaux-IV, Carlos III, Delhi School of Economics, Keele, NES Moscow, NYU Abu Dhabi, Oxford, Paris-X Nanterre, Sussex, and Warwick. The usual disclaimer applies.

${ }^{1}$ Paris School of Economics, IRD, EHESS.

${ }^{2}$ University of Warwick.

3 Institut de Recherche pour le Développement (IRD), Université Paris-Dauphine, PSL Research University, UMR LEDa, DIAL.
} 


\section{Fiscal Capacity and Dualism in Colonial States: The French Empire 1830-1962}

A government able to provide public goods and implement efficient policies is a major ingredient of economic development, if only for "late-starters" (e.g., Gerschenkron 1962; Adelman and Morris 1997; Amsden 2001). Yet, the history of state building is still understudied (Hoffman 2015), and the available evidence disproportionately represents the experience of Western Europe (Tilly 1990, Dincecco 2015) or of today's industrialized countries (Lindert 2004). The recent literature on state capacity focuses on decisions made within formally independent countries (Besley and Persson 2011), while the majority of today's states are direct successors of colonial administrations.

The historical and political science literature views the colonial state, at the same time, as very powerful and very weak. Though Crawford Young (1995) emphasizes that the African colonial state lacked a few attributes of stateness (sovereignty, national doctrine and international existence), he nevertheless describes it as a Leviathan, displaying "the purest modern form of autonomous bureaucratic authority" (p. 160). In contrast, Jeffrey Herbst (2000) characterizes the African colonial state as "administration on the cheap" (p. 73) with "limited ambition" (p. 77) and an unwillingness and inability to extend its control. For Frederick Cooper (2002), African colonial states were "gate-keeper states" (p. 5), able to control the trade flows in and out, but unable to extend power inwards. Outside of Africa, Anne Booth (2007) credits the colonial states of South-East Asia for some effective developmental action.

Postcolonial "successor states" retained a number of features of colonial states, notably because they were a coproduction of colonial rulers and autochthonous elites (Bayart 1993; Cooper 2014a). Herbst sees the persistence of "non-hegemonic rule", and Cooper the persistence of the gate-keeper features. In contrast, Young sees a legacy of authoritarianism, and Mahmood Mamdani (1996) a legacy of “decentralized despotism” (pp. 37-61).

For Cooper (1996, 2002 and 2014b) the period of "developmental colonialism" after World War II is crucial for understanding colonial legacies. However, quantitative studies of African colonial public finances focus on the period before World War II (Frankema 2011, Frankema and van Waijenburg 2014). One notable exception is Gardner's (2012) work on British colonial Africa. Recent works usually focus on British colonies, and studies of the French empire are still rare (with the exception of van Waijenburg 2018, and Frankema and 
van Waijenburg 2014). Further, colonial states are most often only approached from the side of taxation, while it is fruitful to also consider the side of expenditure. Indeed, effective states are not only characterized by their extractive efficiency, but also by their productive efficiency: they are not only able to tax, they are also able to use public funds efficiently (Dincecco 2015, Besley and Persson 2011).

To provide comparative evidence on the states of the second French colonial empire, we built a new database, unprecedented in detail, geographical and historical scope. From administrative archives, we extracted exhaustive revenue and expenditure data, public employment data, and public investment outcomes. We cover the 21 French colonies of Northern and sub-Saharan Africa, and South-East Asia, from their conquest to their independence around 1960. To study the crucial period of transition to independence, we were able to extend some of these data to 1970 .

Colonial states of the French empire had high extractive efficiency, but low productive efficiency. They taxed a lot, but achieved little, because public expenditure displayed high unit costs, and concentrated in areas where French settlers lived and where French firms were active. In that sense, French colonial states were neither casual night watchmen, nor omnipotent leviathans. In 1925, using fiscal tools adapted to different local contexts, they were already extracting 9 percent of colonial GDP on average. Colonial administrations did not stop investing in fiscal capacity when independence became foreseeable in the 15 years following World War II. In the hope of preserving imperial dominance, they taxed more and spent more. In 1955, they were extracting 16 percent of colonial GDP on average. This impressive increase in fiscal capacity was accompanied by large overseas redistribution. While the colonies were largely self-financed during most of the colonial period (at least for their non-military expenditures), net civilian subsidies from France represented 2.7 percent of their GDP in the 1950s. In the same period, France started fighting against liberation movements in Indochina, Algeria and Cameroon, at a financial cost that far exceeded civilian subsidies. Independence, therefore, relieved the colonizer from a growing financial burden.

Though fiscal capacity was comparatively high, and though external financing became more important in the late colonial period, productive efficiency was low. Public expenditure was biased - towards the needs of settlers - and displayed high unit costs, explained in part by the high wages paid to expatriate civil servants. In 1925, the average civil servant in the French empire was paid about nine times the colonial GDP per worker. Bias and high costs meant that despite substantial fiscal capacity the colonies were under-administered. Dualism, 
the existence of high-wage formal enclaves in poor and agricultural economies, was a salient feature of colonial states, and an important legacy.

Independence did not bring any discontinuity. In 1970, new postcolonial states taxed the same share of their GDP as colonial states did in the 1950s, and they were still dependent on French aid for a significant share of their expenditure.

In the rest of the paper, we first provide a short historical background, before presenting the data construction methodology. The third section focuses on tax extraction and distribution across space and time, the fourth section on external financing, and the fifth section on public expenditure and its cost.

\section{France's second colonial empire: geography, economy, settlements and political representation}

We study France's second colonial empire: colonies acquired after 1830 and located in Africa and East Asia (Figure 1). ${ }^{4}$ This section lays down some key elements for understanding the history of colonial states. ${ }^{5}$ Initial economic and demographic conditions determined what colonial governments could tax. Patterns of European settlements and the evolution of political representation of settlers and autochthons are important for understanding the political economy of taxation and spending in the empire. ${ }^{6}$

France acquired its second colonial empire between 1830 and 1919. 1830 marked the beginning of the colonization of Algeria. Tunisia and Morocco were added as protectorates in 1881 and 1912, respectively. Indochina and Africa south of the Sahara were colonized during the second half of the nineteenth century. The last additions to the empire were the former German colonies of Togo and Cameroon, ruled from 1919 as mandates of the League of Nations. In 1954, Indochinese colonies gained independence after a seven-year war of independence. Decolonization was then rapid: Tunisia and Morocco became independent in 1956, Guinea in 1958, all other sub-Saharan colonies in 1960, and finally Algeria in 1962, again after a seven-year war.

\footnotetext{
${ }^{4}$ A few short-lived or small-size colonies were not included in our data collection effort: the League of Nations mandates of Syria and Lebanon; Djibouti; the Comoros and Pacific Ocean islands. We also excluded the remains of the first colonial empire (acquired before 1830): the French West Indies and Guyana, the Réunion Island, and the five trade posts of India.

${ }^{5}$ Online Appendix III provides an extended bibliography on the history of French colonies.

${ }^{6}$ We use the words "autochthons" and "autochthonous" to refer to the local populations of colonies, as opposed to settlers. The word "indigenous" (indigène) was used in the French colonial context, and has a negative connotation. The word "native" was used in the British colonial context with a similar connotation.
} 


\section{Initial demographic and economic conditions}

The regions making the French colonial empire differed in their initial demographic and economic conditions. Table 1 gives estimates of population, urbanization and GDP in the empire at three key dates: 1850, 1925 and 1950. Except in Algeria, 1850 predates French colonization. In 1925, the French empire had reached its greatest extent. 1955 is the eve of independence; Indochina had then just become independent.

Around 1850, what was to become the French colonial empire, including 40.6 million people, was only 12 percent more populated than Metropolitan France. In the following century, population more than doubled throughout the empire, but French population increased by less than 20 percent. In 1955, the empire was more than twice as populated as France was. $^{7}$

\section{[FIGURE 1 ABOUT HERE.]}

We use urbanization rates as of 1850 to gauge differences in economic development. North Africa stood above the rest at 6.6 percent. Indochina and sub-Saharan Africa had urbanization rates below 3 percent, but within Indochina, Cochinchina was more urbanized (5.5 percent), while Madagascar stood above West and Central Africa at 2.2 percent against 0.7 percent. These differences in initial urbanization are in line with what we know of the economic history of these regions and their history of political centralization. North Africa benefited from its very ancient integration into the Mediterranean economy, and from its connections with the Islamic world and the Ottoman Empire (Valensi 1969). In Indochina, Laos and Cambodia were centralized, though weakened kingdoms, and Vietnam had been unified under the imperial rule of the Nguyen dynasty. The Mekong Delta in the south benefitted from superior ecological conditions for rice cultivation and had already attracted a large Chinese immigrant population (Bassino, Giacometti and Odaka 2010). In the nineteenth century, the island of Madagascar had been almost entirely united by the kings of Imerina (Campbell 2005). West and Central Africa, in contrast, did not have a history of strong political centralization. In the regions conquered by the French, the three most salient political structures of the nineteenth century were the Kingdom of Dahomey in present-day Benin, the Toucouleur Empire of al-Hajj Umar Tal in Senegal and Mali, and the moving empire of Samori Ture from forest Guinea to Northern Cote d'Ivoire and Ghana (Reid 2012).

\footnotetext{
${ }^{7}$ Here and in the remainder of the paper we use the word "France" for "Metropolitan France."
} 


\section{[TABLE 1 ABOUT HERE.]}

Our purchasing power parity (PPP) GDP per capita estimates for 1925 (see Data Appendix) give a picture of differences in economic development similar to the one obtained by comparing urbanization rates in 1850 . North Africa was five times poorer than France, but three times richer than the rest of the Empire. ${ }^{8}$ Madagascar was 25 percent richer than Indochina and 43 percent richer than West and Central Africa. ${ }^{9}$ In 1955, after 20 years of contraction during the Great Depression and 10 years of high postwar growth, sub-Saharan Africa remained poorer than North Africa, despite some convergence. Indochina, where World War II preceded a decade-long independence war, had at that point become the poorest of all, with a GDP per capita representing only 75 percent of its 1925 level.

\section{European settlement}

While the French established settlement colonies in North Africa (Europeans represented 8.1 percent of the population in 1925), settlers never represented more than 1.5 percent of population in the rest of the empire (Table 1). In Algeria, settlers from Spain, Italy, and France (the majority) started immigrating in numbers in the decades following 1830. In 1850, they represented 3 percent of population, 5.5 percent in 1870, and more than 10 percent on the eve of World War I. Tunisia was also home to a large population of French and Italian settlers (7 percent of the population in 1913). In Morocco, European settlers never represented more than 5 percent of population. Outside of North Africa, European settlers were few. In Indochina, they represented 0.1 percent of population in 1925. Even in Cochinchina, where the majority lived, Europeans never represented more than 0.6 percent of population. In West and Central Africa, French settlers represented 0.1 percent of population in 1925 and 0.4 percent in 1955. Madagascar welcomed more, in particular from the neighboring Réunion Island: Europeans represented 0.5 percent of total population in 1925 and 1.2 percent in 1955. ${ }^{10}$ European settlement patterns were largely determined by proximity to France, as well as by economic opportunities. The colonies that received the largest number of settlers were also the ex-ante richest and most urbanized. This is true even setting North African colonies

\footnotetext{
${ }^{8}$ The GDP per capita of North Africa during the colonial period was, of course, pulled up by the presence of a large European population with an average income close to that of France. (See online Appendix I.)

${ }^{9}$ South Vietnam (Cochinchina) is estimated to be twice as rich as the rest of Indochina.

${ }_{10}$ Madagascar was also home to a significant Indian minority. Asians, including a small Chinese minority, represented around 0.3 percent of total population in 1925 .
} 
aside: Cochinchina and Madagascar had a larger share of settlers than other colonies in Indochina or sub-Saharan Africa. They were also more urbanized in 1850.

\section{Political representation of settlers and Autochthons}

Whether inhabitants of the colonies had a say in taxation and public spending is a crucial element in understanding the politics of colonial public finances. Before 1946, autochthons in the French colonial empire had, with a few exceptions, no political representation. French settlers had more political rights, especially in Algeria, which France officially annexed in 1848. From 1848 to 1852, and after 1871, French settlers had representation in the French Parliament and Senate. In 1898, they obtained some autonomy in public finance when a local assembly, the "Délégations Financières", was given power to vote the budget. ${ }^{11}$ In contrast, the French settlers of the Moroccan and Tunisian protectorates had no representation in the French Parliament. ${ }^{12}$ Starting in 1881, the French settlers of Cochinchina had one representative. Under the Third Republic, sub-Saharan Africa also had one, elected by the inhabitants of four Senegalese municipalities (les Quatre Communes: Dakar, Saint-Louis, Gorée, Rufisque); French settlers could vote, as could the autochthonous natives of these municipalities who had acquired citizenship. Outside of this exception, access to citizenship was very limited. In 1871, the Crémieux Decree granted citizenship to all Algerian Jews. Algerian Muslims could apply for citizenship starting in 1865, but the procedure was cumbersome and seldom successful (Weil 2005). In the rest of the empire, only soldiers with military decorations could apply. Autochthonous inhabitants of the empire were "indigenous subjects" of France; they had no political rights, but they had obligations. Notably, they could be conscripted into the army; about half a million conscripts from the colonies fought for France during World War I (Frémeaux 2006).

After World War II, autochthons in the empire progressively obtained more political rights. In 1946, the French Union (Union Française) replaced the French empire, and the status of "indigenous subject" was abolished. Autochthons obtained some representation in local assemblies, in the assembly of the French Union and at the French Parliament. Suffrage, however, remained restricted to a heterogeneous list of occupations and social positions (Cooper 2014b p. 137-138). Furthermore, French citizens and autochthons formed two

\footnotetext{
${ }^{11}$ In this assembly, Muslim representatives were granted a minority of 21 seats among the full 69 . These were mostly held by caids who collaborated with the French administration (Bouveresse 2008).

12 They sent representatives to the first and second Constituent Assemblies of the Fourth Republic in 1945-1946, but after that lost representation.
} 
separate electoral colleges that elected the same number of representatives, so that settlers were vastly overrepresented. The protectorates of Tunisia and Morocco were not part of the new French Union. In Indochina, where the war for independence had already started, Vietnam, Cambodia and Laos became "associated states" and did not send representatives to the French Parliament.

In the following decade, increasing anti-colonial pressure from independence movements and from the international community led France to extend franchise. The Defferre reform act ("loi cadre") of 1956 granted universal suffrage to male and female autochthons, put an end to the segregation of electoral colleges, and gave a larger autonomy to territorial assemblies. In Algeria, only with the Fifth Republic in 1958 did political representation of Muslims come closer to their population weight (Weil 2005, p. 108).

\section{Data construction}

Our analysis relies on the collection of firsthand data in French colonial archives. This section highlights the most important points. (The Data Appendix describes in detail the various sources used and the hypotheses made to clean, compile, and homogenize the data.)

We designed collection methodology to obtain homogenously defined spending and tax headings. Our estimates do not depend on the level of decentralization in each region because we consider all public authorities responsible for revenue and expenditure in the colonies. These include the French government (which was responsible for military spending), federal governments, central colonial governments, provincial governments, and auxiliary budget authorities that handled loans, health care, posts, and telegraphs. We collected data yearly, except in federations (Afrique Occidentale Française or AOF, Afrique Equatoriale Française or AEF, and Indochina), where we collected data yearly for the federal government (Gouvernement général), but every three years only for colonial governments (Gouvernements locaux).

Our main variables are Net Public Revenue (NPR), which is public revenue net of loans and subsidies from abroad, and Net Public Expenditure (NPE), public expenditure net of loans and subsidies abroad. These variables are consolidated to avoid double counts arising from transfers between different administrative layers. NPE excludes military expenditure, which was, with a few exceptions, undertaken by the French Ministry of War and Ministry of the Colonies. Public revenue is broken down into different types of fiscal instruments, and public expenditure is broken down into its sectoral allocations. The net deficit (difference between 
NPR and NPE) is broken down into different financing instruments (loans, subsidies, transfers from reserve funds). We also collected data on public wages and employment for six years between 1913 and 1960.

For a couple of variables, notably NPR and NPE, we extended the database past independence until 1970, using various sources. We also collected in statistical yearbooks development outcomes and policy variables such as school enrollment, health personnel, electricity output, roads or railway length, and international trade.

To produce comparable figures of revenue and expenditure, we collected population data from various primary and secondary sources, as well as local price indices, and prices for the year 1937. We express all variables in 1937 PPP-adjusted francs. Finally, to put fiscal figures in economic context and express colonial public revenue as a share of colonial GDP - a standard measure of fiscal capacity - we dedicated a special effort to devise GDP estimates for France and each colonial territory. We combined national accounting exercises (starting in the 1950s) and historians' estimations of GDP growth in volume (see Data Appendix).

Though we produced data for (almost) all years of the colonial period, our presentation relies on the detailed analysis of two key years, 1925 and 1955. In 1925, France's second colonial empire had reached its greatest extent. The French civilian administration had fully replaced the military, and could draw stable fiscal revenue from the colonial economies. 1955 corresponds to the late colonial period: decolonization had just begun with the independence of Indochina in 1954. (Our figures for Indochina are from 1953/54.) Tunisia and Morocco were about to get their independence. Algeria's liberation war had just started, and France had started running large development plans in the colonies.

\section{Fiscal extraction: high and rising}

In 1925, net public revenue represented 8.9 percent of GDP in the French colonial empire. It kept rising in the following decades, reaching 15.9 percent in 1955. French colonial states obtained these high levels of fiscal extraction with fiscal tools adapted to the local geographic, demographic, and economic context. In places where they could tax a large urban population, they used modern fiscal tools. In poorer regions of the empire, the French Republic resurrected Ancien Régime fiscal tools, such as monopoly revenue, head taxes, and corvée (forced labor). 


\section{A sizeable colonial state}

In 1925, the revenue to GDP figure of 8.9 percent is far from small. While the public revenue of Metropolitan France then represented 16.5 percent of French GDP, it was only 13 percent 25 year before, in 1900. Another way to see this is to consider other parts of the world in the 1920s. Peres-Cajías (2017) provides figures for Latin America, but only for the tax revenue of the central government (excluding lower-level administrative divisions and nontax revenue). In the 1920s, the tax revenue of the central government in Madagascar (7 percent) and Indochina (6 percent) was roughly the same as in Chile ( 7 percent) and larger than in Brazil (5 percent). In North Africa (3.9 percent) and West and Central Africa (4.5 percent), it was larger than in Columbia, Bolivia and Peru (less than 4 percent). ${ }^{13}$ Colonies of the British empire are a natural comparison. Ewout Frankema and Marlous van Waijenburg (2014) show that, in Africa, colonizer identity was not an important determinant of the level of fiscal extraction. In a companion paper, we show that, in West Africa, geographical neighbors colonized by the British or the French had very similar levels of public revenue per capita throughout the colonial period (Cogneau, Dupraz and Mesplé-Somps 2018). Under the doctrine of self-financing that applied from 1900 to World War II, French colonies received practically no subsidies from France. They did not pay for military expenditure, and their debt service was limited. France spent some 3 percent of GDP in debt service and 4 percent on the army. As a result, when we consider net civilian public expenditure as a percentage of GDP, we find the same figure of 8 percent for France and its colonies (Table 2, line 3). Because France was about 10 times richer than its colonial empire in 1925, the size of the state is about 10 times higher in France when we express expenditures in 1937 francs per capita. The ratio is even higher if we also consider defense because military expenditure directly allocated to the colonies (including conscription) represented only a small share of French military expenditures. ${ }^{14}$

Though net public revenue varied within the empire (last four columns of Table 2), the variance was relatively limited: 12.5 percent of GDP in Indochina, 9 percent in Madagascar, and 8.3 percent in North Africa. If settler colonies of North Africa had more than twice the levels of public expenditure per capita as Indochina or Madagascar, it was because they were

\footnotetext{
${ }^{13}$ It was more than 10 percent only in Uruguay. Sokoloff and Zolt (2007) give 1930 figures of 7 percent for Argentina, 8 percent for Brazil, 6 percent for Mexico, and 9 percent for Venezuela.

14 The high figure for North Africa in 1925 (107 francs) is due to the Moroccan Rif War.
} 
richer, and not because of higher taxation. ${ }^{15}$ Net public revenue as a share of GDP was lower in West and Central Africa (5.4 percent), and particularly low in AEF (4.0 percent) and Cameroon (2.6 percent). However, the difference between these colonies and the rest of the empire is reduced when we take forced labor into account. In West and Central Africa, and in Madagascar, a labor tax, the prestation, required Africans to work a fixed number of days per year in local public works. In addition, some military conscripts worked on infrastructure projects (Fall 1993). Because labor payments are difficult to value, we do not consider them in our figures (except when they were rebought in cash). Using the valuations of van Waijenburg (2018), who uses unskilled labor minimum wages to value the prestation, increases the share of public revenue in GDP in West and Central Africa from 5.4 percent to 6.8 percent. Including conscripted labor could bring the figure even closer to the rest of the empire. In Madagascar, including prestation labor increases the share of public revenue in GDP from 9 percent to 9.9 percent, bringing it closer to the high level of fiscal extraction of Indochina.

\section{[TABLE 2 ABOUT HERE.]}

In the 30 years following 1925, state size increased tremendously, both in France and in its colonial empire (second panel of Table 2). The only exception was Indochina, where the independence war immediately followed World War II. The last data point we have, in 1953, one year before independence, shows a decrease in GDP per capita (see Table 1) and in net public revenue (from 12.5 percent of GDP in 1925 to 9.5 percent). In France, public revenue rose from 16.5 percent of GDP in 1925 to 26.3 percent in 1955 , or 33.4 percent if social security transfers, which increased a lot after World War II, are included. ${ }^{16}$ In the empire, public revenue increased from 8.9 percent in 1925 to 15.9 percent in 1955 , or 17.1 percent if we include social security funds established after 1944 in North Africa. An examination of the tax revenue of the central government shows that the tax capacity of North Africa and West and Central Africa was, at 10 percent and 11.8 percent respectively, comparable to the tax capacity of Brazil (10.2 percent) and Chile (12.7 percent) in the 1950s, while the tax capacity of Bolivia, Columbia, Guatemala and Peru ranged between 4 percent and 8 percent (Peres-

15 These results are in line with those of Frankema (2010), who shows that, among British colonies in the 1911-1937 period, "partial settlement colonies" (such as South Africa and South Rhodesia) rank below the richest non-settler colonies (such as the Gold Coast or Kenya), but far above the very populated Nigeria.

16 These social security transfers represented only 0.05 percent of GDP in 1925 France, and were then non-existent in the colonies. 
Cajías 2017). ${ }^{17}$ Because the colonies started receiving large net transfers from France after World War II (see below), the increase in state size is even more striking if we consider public expenditure, which boomed from 8.0 percent of GDP in 1925 to 19.1 percent in 1955. Public revenue increased the most in West and Central Africa, rising from 5.5 percent of GDP in 1925 to 13.9 percent in 1955 , partly because the initial figure does not take the monetary value of forced labor into account, and is therefore underestimated.

To give a better view of historical trends, Figure 2 shows the year-to-year evolution of net public revenue as a share of GDP from 1890 to 1970 in each colony or federation. Contrary to Table 2, these series do not include the revenue of second-level administrative divisions (municipalities), because our series for them are patchy. This mainly affects Algeria, where municipalities represented 20-25 percent of public revenue (see Data Appendix). Overall, public revenue decreased during World War II as it had during World War I. Public revenue then peaked dramatically in the 1950s, both in North Africa and in West and Central Africa. Madagascar stands as an exception with a rather stationary profile. At the end of the decade, as colonies gradually cut ties with France, no marked change in public revenue occurred. In West and Central Africa, net public revenue fell in the years leading to independence in 1960, possibly because of administrative disorganization as the French prepared to leave and dismantled the federations. Nevertheless, public revenue quickly recovered, and, at the end of the 1960s, it was back to the level reached around 1955.

Four decades later, in 2010, the independent states corresponding to the former French empire were collecting as much as 26 percent of GDP in public revenue (bottom panel of Table 2), 30 percent with social security contributions. If we exclude oil and mining from both revenue and GDP, the figure falls to 20.6 percent (without social security). ${ }^{18}$ By 2010 , Vietnam, Cambodia and Laos (formerly Indochina) had double the level of fiscal extraction as in 1955. Elsewhere, excluding oil and mining, levels of fiscal extraction in 2010 were similar to those in 1955: 22.1 percent in 2010 compared to 19.1 percent (1955) in North Africa; 11.2 percent compared to 14.6 percent in Madagascar, and 15.3 percent compared to 13.9 percent in West and Central Africa.

\footnotetext{
${ }^{17}$ Sokoloff and Zolt (2007) give 1950 figures of 10 percent for Argentina, 9 for Mexico, and 18 for Venezuela.

18 These sectors, which boomed after independence, are easy revenue-extraction sources, even for states with low administrative capacity, but revenue from these sectors is very volatile.
} 


\section{Fiscal adaptation}

To extract a high and increasing share of GDP, the French colonizers adapted the fiscal structure to different contexts and historical periods. We categorized fiscal instruments according to their implied degree of state capacity. This encompasses a broad range: from tools involving only light administrative management (such as the head tax or capitation) or monopolies on the sale of certain goods (such as alcohol or salt) or services (revenue of posts and telegraphs); to taxes on external trade that did not require government presence outside the port of entry; to intermediate taxes requiring larger administrative capacity; to modern taxation (such as income and turnover taxes) requiring the frequent collection or selfdeclaration of detailed economic information on individuals and firms. (For a more detailed classification, see the Data Appendix). ${ }^{19}$

The distinction between direct and indirect taxes that is often used as a measure of fiscal capacity is not suited to the colonial case. For example, the head tax (capitation), a lump-sum tax levied on every individual except children, the elderly and the physically impaired, was, in practice, not costly in terms of administrative management; village-level colonial administrators were not needed because local chiefs levied the tax (Zucarelli 1973). ${ }^{20}$

Table 3 displays the share of different tax instruments in GDP in France and the four regions of the empire. ${ }^{21}$ In 1925 France, there was no capitation, trade taxes represented only 0.8 percent of GDP and modern and intermediate taxes represented 11.3 percent of GDP -80 percent of net public revenue.

In the empire, the fiscal structure of the North African colonies and protectorates was the closest to France. Capitation represented less than 0.1 percent of GDP, intermediate taxes about 2.5 percent and modern taxation already 1.2 percent (16 percent of net public revenue), while it remained marginal in the rest of the empire. Algeria, first, and Tunisia, second, had gradually replaced Ottoman taxes by copying French taxes, such as direct taxes on wages, benefits, and other types of incomes. A general income tax was introduced in 1919 in Algeria, and 1928 in Tunisia. In Tunisia, the revenues from taxes on income drawn from agricultural exports (appearing as intermediate taxes in our classification) gradually overtook the revenues of ancient taxes on agricultural inputs such as trees, land, and cattle (Nicolai, 1962, p. 443). In

\footnotetext{
${ }^{19}$ Monopoly revenue does not include the receipts of public railway companies, but it does include their excess revenue when they are transferred to the government's budget (see Data Appendix).

${ }^{20}$ The local chiefs received wage payments and a share of the amount collected. The lump-sum amount of the capitation varied, as well as the minimum age threshold. Civil servants and soldiers were exempted.

${ }^{21}$ Table 3 (like Figure 2) does not consider the revenue of municipalities. This is why the various tax instruments do not sum to the net public revenue of Table 2.
} 
Morocco, the bulk of modern taxation was, before the 1940s, a tax on agricultural income called tertib. ${ }^{22}$ In North Africa, trade taxes, at 1.2 percent of GDP, were higher than those in France, but lower than those in the rest of the empire. They remained limited because Algeria and Tunisia formed a customs union with France so that, with a few exceptions, neither bilateral exports nor imports were taxed. Only dock dues (octroi de mer) applied, as they applied to trade with other countries. Trade taxes were higher in Morocco (2.3 percent of GDP), where the protectorate treaties prevented a customs union with France.

\section{[TABLE 3 ABOUT HERE.]}

Outside of North Africa, the colonial fiscal structure relied heavily on Ancien Régime tools such as capitation and monopoly revenue. In Indochina, capitation represented 1.6 percent of GDP, but the striking figure was the weight of monopoly revenue - 4.2 percent of GDP in 1925. Revenue of the government monopoly on opium alone represented 1.4 percent of GDP. Because opium was purchased mainly by wealthy ethnic Chinese, this was "deliberately a Chinese tax" (Bassino 2000, p. 281). As in North Africa, the customs union with France limited taxation of trade, which accounted for only 1.5 percent of GDP. Modern taxation represented 0.2 percent of GDP - a much smaller percentage than in the settler colonies of North Africa. From 1920 onwards, European settlers in Indochina paid a wage tax and a minimal lump-sum tax on 12 income brackets. Between 1938 and 1941, a general income tax was introduced, and extended to the autochthonous population. Though European settlers in Indochina were taxed, and though they were much richer than the rest of the population, and richer than European settlers in North Africa, they were too few to generate large fiscal revenue. ${ }^{23}$

Sub-Saharan African colonies relied heavily on capitation for public revenue. In West and Central Africa, it represented 1.5 percent of GDP. If we follow van Waijenburg (2018) and take the labor tax into account, we find that forced labor represented 1.4 percent of GDP, so that 2.9 percent of GDP (53 percent of net public revenue) was collected using regressive taxes weighing practically exclusively on autochthons. In Madagascar, capitation rates had been higher than in West and Central Africa since the beginning of the twentieth century (Jacob 1987). In 1925, capitation represented almost 3 percent of GDP. Using the estimates of

22 The tertib was originally introduced by the sultan Moulay Abdelaziz in 1901, and then withdrawn, before being revived by the French administration in 1915 .

${ }^{23}$ See population and income shares in online Appendix 1. 
van Waijenburg (2018), we find that forced labor represented 1 percent of GDP - a bit less than in West and Central Africa. ${ }^{24}$ Intermediate taxes and monopoly revenue were also higher in Madagascar than in West and Central Africa; these sources of revenue, along with higher capitation rates, explain the higher level of fiscal extraction. Modern taxation was inexistent in sub-Saharan Africa, and colonial governments relied more heavily on trade taxes. Such taxes represented 2.3 percent of GDP in Madagascar and 1.9 percent in West and Central Africa. Like Algeria and Indochina, Madagascar was in a customs union with France, so that import duties were limited. However, taxes applied to the consumption of a few imported goods, and to exports. In West and Central Africa, import tariffs could be fixed according to domestic conditions (Bernard 1913; Cornevin 1972, pp. 294-295). Within that region, the potential for trade taxes explains why public revenue was higher in West Africa (AOF and Togo) than in Central Africa (AEF and Cameroon); West Africa had been more outward oriented since the times of "legitimate commerce" in the first half of the twentieth century (Law 1995). ${ }^{25}$

Net public revenue increased everywhere between 1925 and 1955, and especially in the 15 years following World War II. In France, new revenue mostly came from an increase in direct and indirect modern taxation, which climbed from 4.4 percent to 12.1 percent of GDP (bottom panel of Table 3). In the colonies, the contrast is again between the settler colonies of North Africa, where modern taxation was responsible for a large part of the increase in revenue, and the rest of Africa, where the colonizer relied on trade taxes, though the fiscal structure was also modernized.

Our figures for Indochina are for the year 1953, one year before independence. The French grip had then become much weaker, the autonomous government of Vietnam had abolished capitation, and monopoly revenue and intermediate taxes had lost weight. Modern taxation had progressed, but only moderately. As the colonial state was losing ground, trade taxation had become the dominant source of revenue, now representing 3.6 percent of GDP.

In North Africa, modern taxation was responsible for almost half of the increase in fiscal extraction over the period, increasing from 1.2 to 5.1 percent of GDP, while monopolies and intermediate resources also increased substantially. Import tariffs were raised in Tunisia and

24 The colonizer increased capitation rates in the beginning of the twentieth century to break with the unpopular forced labor practices of the precolonial Merina Kingdom (Jacob 1987, Campbell 2005). This could explain why forced labor was less important in Madagascar than in the rest of Africa. At the same time, conscription reservists were used intensively between 1928 and 1945 (Fremigacci 2014 p. 50); they are not counted in van Waijenburg's estimates.

${ }^{25}$ The contrast between French West and Central Africa is similar to the contrast between British West and East Africa put forward by Frankema (2011) and Frankema and van Waijenburg (2012 and 2014). 
Morocco during the Great Depression and World War II, and went down only slightly afterwards, but the overall increase in trade taxes was modest.

In sub-Saharan Africa, the colonizer also modernized the tax structure, but primarily used trade taxes to increase public revenue. The capitation decreased modestly in Madagascar, and increased in West and Central Africa, from 1.5 to 2 percent of GDP. Modern taxation, in the form of income and turnover taxes, which were inexistent in 1925, increased to represent more than 1.5 percent of GDP. In the colony of Senegal, which was wealthier and welcomed more French settlers, the schedular taxes on profits and wages introduced in 1941 and the general income tax of 1930 raised, after 1946, more revenue than the capitation, and the turnover tax almost as much. Yet, the extent of this modernization was more limited than in North Africa. In sub-Saharan Africa, trade taxes explained most of the increase in public revenue: their share in GDP more than doubled to represent about 5.5 percent of GDP. This was mainly the result of a rise in tax rates, in particular on imports. Though African trade boomed after World War II, GDP boomed as well, so that the boom in trade alone cannot explain the increase in the share of trade taxes in GDP. ${ }^{26}$

\section{Increasing progressivity in taxation?}

The construction of the welfare state in twentieth century Europe went with the gradual modernization of taxation, because the collection of up-to-date information on individuals or firms allowed more progressive tax schedules. Does it mean that taxation was more progressive in the settler colonies of North Africa as compared to the rest of the colonial empire? Does it mean that the progressivity of taxation increased in the last decades of colonization? An apparently more modern tax structure could actually reflect only colonial inequality and/or structural change in colonial societies. Where Europeans obtained a higher share of income, the share of revenue from modern taxes or from import duties was mechanically higher. Likewise, where or when more autochthons migrated to cities and obtained wage jobs, the tax structure looked more modern due to the same composition effect.

Though our data do not allow us to conduct a precise incidence analysis, we use various sources, and in particular novel income tax tabulation data from Alvaredo, Cogneau and

\footnotetext{
${ }^{26}$ In Madagascar, the share of imports and exports in GDP actually decreased from 56 percent in 1925 to 32 percent in 1955. In West and Central Africa, it increased from 31 percent to 40 percent. Exports increased from 14 to 18 percent of GDP and imports from 17 to 22 percent. In 1925, the effective rate of taxation was 2.1 percent on exports and 9.6 percent on imports. The increase in trade alone would then explain an increase in the share of trade taxes in GDP of only $0.021 \times 0.04+0.096 \times 0.05=0.56$ percentage points. The effective tax rate on exports increased to 9.3 percent in 1955 , the tax rate on imports to 18 percent.
} 
Piketty (2017) to implement simple numerical simulations on the distribution of the tax burden. We consider three groups: Europeans, the autochthonous non-poor, and the autochthonous poor, for the years 1925 and 1955 and for Algeria, Tunisia and AOF. This is presented in detail in Online Appendix I, we only report here the conclusions obtained.

In Algeria, progressivity had already improved before 1925 with the suppression in 1919 of the so-called "Arab taxes" inherited from the Ottomans and their replacement by a general income tax. Both for Algeria and Tunisia, our simulations suggest that the tax system was at least neutral, if not mildly progressive in 1925. Between 1925 and 1955, tax progressivity unambiguously increased in Algeria and Tunisia, though this increase was perhaps modest. In AOF, the tax system was possibly regressive in 1925 (notably because of forced labor), but this possibility seems very unlikely in 1955 . Yet, given the range of the confidence intervals obtained, the simulations do not allow us to assert for sure that tax progressivity increased in AOF. Likewise, it is very hard to assert for sure that Algeria and Tunisia had a more progressive tax system than AOF.

To take stock, French colonial states managed from the start to extract significant fiscal resources, by taxing autochthonous populations sometimes heavily. As time went, and especially after World War II, they succeeded in doubling extraction while shifting to more modern tax systems with better distributive properties. While, during most of the period, colonial civilian expenditure was largely self-financed, the increase in fiscal capacity after World War II came with an increase in external financing in the form of grants from France.

\section{External financing: from self-financing to aid dependency}

Figure 3 displays net grants from France as a proportion of a colonial territory's GDP. At the beginning of the twentieth century, for some colonies like Algeria, Madagascar or AEF, grants could represent 15 to 25 percent of expenditure, at a time when the fiscal apparatus was still under construction. Yet, as expenditure was also low, this temporary contribution never went above 3 percent of local GDP, and the cost to France was very limited. In Indochina, net grants from France were systematically negative from 1904 onward, which means that surpluses from Indochinese budgets were financing the French state.

Between 1920 and 1944, the colonial empire was almost self-financed. The first exception was Morocco in the 1920s when the colonial state was still new. The second exception was Central Africa (AEF), where grants represented up to 0.8 percent of GDP over the period. Transfers to AEF peaked between 1920 and 1924, the period of Minister Sarraut's 
plan, taken by some as the first developmental attempt in the empire (Cornevin 1972 pp. 281290). In the 1930s, as the Great Depression was unfolding, state-guaranteed long-term loans financed large infrastructure projects. Colonial governments used these loans mainly for the completion of railway lines like the "Congo-Océan" in AEF or the "Fianarantsoa-Côte Est" in Madagascar. These loans were still being reimbursed in the late 1950s, but thanks to the large inflation of the 1940s that multiplied prices by 14, real interest rates on these loans ended up being negative, so that they represented a less visible subsidy to the colonies from French bondholders.

\section{[FIGURE 3 ABOUT HERE.]}

In 1946, the Economic and Social Development Investment Fund (FIDES) was created to finance large-scale infrastructure projects in sub-Saharan Africa. Though the colonies also contributed to this fund, the contribution of France was 70 percent of the total. As a result, as can be seen in Figure 3, after 1946 net grants from France as a share of GDP took off in Madagascar (2.4 percent of GDP on average for 1946-1960) and even more impressively in West and Central Africa (3.5 percent). During the same period, North African colonies financed developmental projects through loans under the Modernization and Equipment Fund (FME), renamed Economic and Social Development Fund (FDES) after 1955 (Saul 2016 p. 47). Morocco and Tunisia received no direct subsidies before independence in 1956, yet ongoing research suggests that the post-independence governments did not reimburse some of the loans. Algeria started receiving large amounts of French aid in 1956, two years into the liberation war. This culminated in 1959-1962 under the "Constantine Plan", aimed at industrializing the country, with a peak at 16.4 percent of Algerian GDP in 1961 (5.8 percent of GDP on average between 1946 and 1962).

The colonial empire definitely turned more costly for France in the last 15 years of colonization. Yet, even during this period, France's total financial contribution to colonial civilian expenditure reached 0.39 percent of its own cumulated GDP, below the aid target fixed today by the OECD for its members ( 0.7 percent). Then decolonization and the transformation of these subsidies into foreign aid allowed France to save money. The amount of French aid directed to Algeria decreased quickly after 1963 to represent only 2 percent of Algerian GDP in 1969, Madagascar also experienced a large downfall below 1 percent, while in West and Central Africa the share of French aid in GDP stabilized around 3 percent. 
Figure 4 provides a synthetic view of all sources of public finance in the French empire, expressed as a percentage of the total empire's GDP. ${ }^{27}$ Between 1900 and 1950, total civilian public expenditure in the empire was overwhelmingly financed by local public revenue. Financial transfers from France were large, but almost completely in the form of military expenditure, far larger than civilian subsidies. From 1833 to 1962, military expenditure in the empire represented on average 57.7 percent of civilian expenditure, 6.1 percent of the empire's GDP and 0.8 percent of France's GDP; the corresponding figures for civilian transfers were respectively 10.7, 1.1 and 0.14 percent. Military spending was high during the conquest of Algeria, peaked in the 1880s with the conquest of Tunisia and Indochina, and boomed again with the liberation wars of Indochina and of Algeria, while military presence was also increasing in other colonies of sub-Saharan Africa after 1946. Though France kept a few permanent military bases in its former empire, decolonization definitely decreased France's military expenditure. Except for some expenditure in infrastructure and health, we never consider the military expenditure of France as an item of public expenditure for the colonies. Yet, once they became independent, the former colonies started developing a national defense budget, so that we could consider part of France's colonial military spending as subsidizing their defense expenditure. Military expenditure in the domestic budget of independent Morocco (after 1957) weighed 13 percent of total expenditure, or 1.5 percent of domestic GDP. ${ }^{28}$ If we adopt this 1.5 percent ratio of GDP to define counterfactual military spending absent colonialism, then we find that the subsidization of defense expenditure by France represented a 0.18 percent transfer in terms of French GDP, bringing total subsidies to colonies to $0.14+0.18=0.32$ percent over $1833-1962$. Overall, French "aid" to its colonies was definitely modest.

\section{[FIGURE 4 ABOUT HERE.]}

To take stock, though French aid to its colonies was limited if we consider the entire colonial period, it increased in the last two decades of colonization, in particular in subSaharan Africa. In the same period, fiscal extraction, which was already substantial, increased

${ }^{27}$ As the empire expanded over time, so does the geographical coverage of the GDP denominator; colonies enter as their first budget account becomes available (first Algeria in 1833, then Cochinchina in 1862, then Senegal in 1865 , etc.), then come out when they get their independence.

${ }^{28}$ It was 11.7 billion francs; Roy. du Maroc, Tableaux économiques du Maroc 1915-1959, p. 261. In contrast, according to Amin's estimates (1966 pp. 281-284), Algeria in 1963 had the largest army in Africa, and spent 70 billion francs on it, meaning 5.2\% of GDP, not even counting the pensions of veteran moujahidins (30 billion). 
to unprecedented level. As a result, in 1955, net civilian public expenditure represented almost 20 percent of GDP in the French colonial empire. As the next section shows, the high and rising extractive efficiency of the colonial state, accompanied in the late colonial period by large external financing, was not accompanied by productive efficiency.

\section{Biased expenditure and high wage cost}

The true limitation of the colonial state was not its fiscal capacity, but its colonial nature. Its expenditure was biased, serving first the needs of French settlers and companies. It was also plagued with high unit costs, in particular because of high wages, partly explained by the presence of very well paid French civil servants. In the end, the legacy of the French colonial state was dualism, the coexistence of modern, formal-sector enclaves and a traditional, informal sector (Boeke 1953, Lewis 1954). One key aspect of the dualism created by French colonial states was the existence, in poor, agricultural economies, of a high-wage public sector providing public goods at European standards to urban enclaves.

\section{Biased expenditure}

The colonial state had to serve first the interest of French settlers and capitalists, by favoring costly investments in railways and harbors to connect mines and plantations, and by providing settlers, mainly agglomerated in cities, with public services (health, education, electricity) at the standards prevailing in France. Table 4 shows the sectoral allocation of public expenditure as well as a few development outcomes in France and the colonial empire in 1925 and 1955. Like for public revenue, we organized data collection, homogenization and aggregation to make expenditure headings comparable across space and time.

In all colonies, a large share, between 32 and 50 percent, of public expenditure went to infrastructure and what we call "production support" - subsidies to private and public companies and expenditure on public services to enhance and support production, like posts, mining or agricultural research. In North Africa, colonial governments also directed public subsidies to the settlement of French farmers. A large fraction of production support expenditure went to railways, in the form of subsidies to private companies, in direct investments financed by loan or buying back the capital of private companies, or in subsidies to the operating national company. Only in post-1945 Indochina did this kind of expenditure represent a smaller share (24 percent in 1953), because the independence war prevented infrastructure projects. The share of infrastructure and production support in expenditure was 
overall higher in the colonies than in France, but the years 1925 and 1955 are not representative of longer-term patterns, as the reconstruction effort after World War I and World War II were then absorbing a large part of French public spending. Before 1914 and between 1926 and 1939, the share of production and infrastructure expenditure was 10 to 20 percentage points higher in the colonies than in France. Yet, despite some catch-up between 1925 and 1955, the gap between France and its colonies in electricity output, roads and railways remained wide (Table 4). In 1955, kWh per capita were 30 times as high in France as in the colonies, road meters per capita 3 times as high, and railroad meters per capita 4.5 times as high (bottom panel of Table 4, lines 3-5).

\section{[TABLE 4 ABOUT HERE.]}

North African colonies received more electricity than the rest of the empire: in 1955, the number of kWh per capita was 8 times higher than in Madagascar, 15 times higher than in West and Central Africa. ${ }^{29}$ However, electrification was limited to urban centers, where European settlers lived. If we consider instead public investments that could not easily be targeted only at cities, like road meters per capita, North Africa was not particularly better endowed in 1955. Agricultural investments remained concentrated in regions with high potential and a significant presence of European farmers or traders, like the groundnut basin in Senegal, the inner Niger delta for cotton and rice in Soudan, or the rice-producing Mekong delta in Cochinchina. ${ }^{30}$ Despite this concentration, and despite high investment and operating costs, colonial infrastructure was still transformative. In particular, railway lines and major roads stimulated autochthonous initiative in cash crops, and spurred the growth of cities (Jedwab and Moradi 2016).

As for social spending, it was not a priority of colonial governments. In 1925, the education sector represented 7.3 percent of public expenditure and 13 percent of public employment in the colonies, versus 20.3 percent and 32 percent in France (top panel of Table 4, line 5). In 1955, education expenditure had increased to 11.3 percent of expenditure and 18 percent of employment in the colonies, while it had remained stable in France in employment

\footnotetext{
${ }^{29}$ The average of Metropolitan France is perhaps not the best comparator, if only to assess the post-WW2 infrastructure effort. If we instead take one of the most disadvantaged département in mainland France, the Creuse, the density of electricity was at par with Algeria in 1925, but twice the Algerian level in 1955, at 192.8 $\mathrm{kWh}$ per capita. The island of Corsica had almost no electricity in 1925 (1.3 kWh p.c.), but stood above Algeria in 1955 , at $130 \mathrm{kWh}$ p.c. From this standpoint, the Corrèze (another relatively poor département next to the Creuse) was indeed preferred to the Zambèze, as urged by the famous motto of the "Cartierist" political movement in the 1950s ("La Corrèze plutôt que [rather than] le Zambèze!").

${ }^{30}$ Dumont (1966) harshly criticizes this biasedness of post-WW2 investments under the FIDES.
} 
share, and even decreased in expenditure share. ${ }^{31}$ Education was a more important item of expenditure in North Africa than in other colonies (Table 4, top and bottom panels, line 5). It was particularly true in Algeria, which spent 11-12 percent of public spending on education in both years, and where education personnel represented 36-37 percent of the civil service. Yet this educational effort was dramatically biased towards European settlers. In Algeria, budget accounts report a specific credit line for the European sub-sector, which received 78 percent of total education expenditure in 1925 and 82 percent in 1955. In 1925 Morocco, the corresponding figure was also 79 percent. In terms of expenditure per pupil, our calculations (not reported) show that European children in Algeria enjoyed the same level as children in France, while Algerian children received no more than in other parts of the empire.

Among autochthons, primary school gross enrollment rates were extremely low in 1925: 3.5 percent on average. In 1955, enrollment had increased, yet only to 14.5 percent. Some colonies were doing better than the rest: Tunisia, Madagascar and Cameroon displayed the highest rates, around 30 percent, followed by Togo (23 percent). In Tunisia, modernization attempts in the $19^{\text {th }}$ century led to the foundation of the Sadiki high school in 1875 (Sraieb 1993). Then under French rule, bilingual "Franco-Arab" and "modernized" koranic schools likely encouraged autochthonous enrollment. In contrast, in Algeria, schools only taught in French, and the local government of settlers explicitly rationed the provision of education to autochthons (Ageron 1979, pp. 152-167 and 532-536). Enrollment of Algerian children, however, accelerated in the 1950s so that at independence in 1962, the rate was 33 percent, double the level of 1955. In the highlands of Madagascar (Imerina), a few Protestant missions offered some schooling as early as in the $1820 \mathrm{~s}$, and were then placed under state control by king Radama I (Campbell 2005 pp.86-89). In Togo and Cameroon, mission schools came in under German rule, yet it is only after World War II that the secularist stance of the French Republic was relaxed enough to authorize and subsidize a larger number of mission schools (Cogneau and Moradi 2014; Dupraz 2019). In secondary education, only Tunisia, followed by Madagascar and Cameroon, lay significantly above the average, although at very low levels (respectively $3.4,1.8$ and 0.8 percent of 11-18 year-old indigenous children, while at the same time this gross rate reached 19.2 percent in France). At the end of the day, putting settlers apart, the educational performance of the settlement colonies of North Africa was far from impressive.

\footnotetext{
${ }^{31}$ In France, the share of education in public expenditure dropped after WW2 to 13.5 percent, but not the share in employment ( 35 percent). The drop in the expenditure share is mainly explained by the temporary increase of public works for post-WW2 reconstruction.
} 
For health, comparing public expenditure shares is not as informative as for education. In France, the provision of health assistance and medical services relied mainly on the private sector on the one hand, and on lower administrative levels on the other (départements and municipalities, which are not part of our estimates). ${ }^{32}$ It is only under the Fifth Republic (after 1958) that a national and centralized public health system took off. In North Africa as well, health was financed by lower level administrative divisions and the private sector. The share of health in public expenditure was very similar in France and in the empire in 1925 (5.9 vs 5.8 percent) and in 1955 (13.5 vs 11.3 percent). France had 10 times the number of public health personnel per capita in 1925, but the difference between the settler colonies of North Africa and the rest is not striking, with North Africa and Madagascar at the same level (top panel of Table 4, line 9). When we consider the total number of health professionals (physicians, pharmacists, dentists and midwives) per capita, including the private sector and lower level administrative divisions, France had 30 times more health personnel than the empire in 1925 (top panel of Table 4, line 10). Within the empire, North Africa had about 3 times more health personnel than the rest of the empire, but there was some convergence between 1925 and 1955 (bottom panel of Table 4, line 10).

Sovereignty expenditure in general administration, financial services, justice and security represented a third of colonial public expenditure and half of colonial public employment in 1925 (top panel of Table 4, lines 11-12). These shares would be even higher if we were to include military spending funded by France. The share in employment lay way above the share in expenditure because security involved many low-pay autochthonous policemen, especially outside of North Africa. Policemen represented 59 percent of sovereignty employment on average. In 1955, sovereignty spending had lost its weight in Madagascar and in West and Central Africa, both in the budget and in the labor force. The number of policemen per capita did not increase much, but the police force was professionalized, and wages in this sector were significantly raised, especially after WWII.

Overall, the ratio of education and health investments to "order" spending (Frankema 2011, p. 144) had increased everywhere after 1945, signaling a more developmental orientation, and non-settler colonies had caught up with North Africa in this respect. ${ }^{33}$ Public

32 See footnote of table 4 . We were able to recover expenditure shares of first level administrative divisions in the colonies, but not in Metropolitan France. Employment share are for the central government everywhere.

${ }^{33}$ Circa 1925, the structure of expenditure in French West and Central Africa is very similar to the one observed for British Africa by Frankema (2011, p. 142). Our own analysis in a companion paper suggests that in West Africa, British colonies went through the same evolutions as French colonies after WWII (Cogneau, Dupraz and Mesplé-Somps 2018). 
expenditure remained significantly biased, but the bias had decreased, outside of the Indochinese wartime exception. The developmental turn of colonialism did not achieve much however, partly because of the low productive efficiency of colonial public expenditure. In particular, colonial civil service wages were high from the start and remained high after World War II as public employment increased.

\section{High wage costs}

The wage costs of colonial states were high, mainly because of the high emoluments and bonuses paid to European civil servants. Table 5 displays civilian expenditure per capita, public employment per 1,000 inhabitants and the annual average public wage in France and in the colonial empire in 1925 and 1955 . We express monetary figures in 1937 francs adjusted for purchasing power parity, using a basket of consumption goods for deflation (see Data Appendix). Because of vast differences in GDP per capita and wages, this way of expressing public expenditure clearly overstates differences in the volume of public goods and services provided. In the absence of detailed information on the price of various government goods and services, building a specific public spending deflator is impossible, but we show the number of civil servants per 1,000 inhabitants. This indicator might understate differences in public services provision, as it does not consider the skill content of various occupations.

In 1925, France raised 16.5 percent of GDP in public revenue versus 8.9 percent for the colonial empire, but the difference in the number of civil servants per capita was much more striking. France had 11.9 civil servants for 1,000 inhabitants, more than five times the average for the empire (2.2). Within the empire, though North Africa was the region where public expenditure per capita was the highest, it was not the region where public employment per capita was the highest (2.9 employees per 1,000 inhabitants). Madagascar, with a high fiscal extraction and the lowest civil service wages, had the highest public employment per capita, with 3.9 employees per 1,000 inhabitants (Table 5, line 2).

\section{[TABLE 5 ABOUT HERE.]}

If public wages were proportional to GDP per capita, differences in public employment would reflect differences in revenue as a percentage of GDP. This was not the case because differences in public wages were much smaller than differences in GDP per capita. In 1925, while GDP per capita was 10 times lower in the colonies than in France, the average annual 
public wage was only 20 percent lower (Table 5, line 3). Indochina was 14 times poorer that France, but the average public wage was the same as in France (see Online Appendix II for a discussion of the high wages prevailing in Indochina in the 1920s).

To measure wage dualism, here the existence of high public wages in a low-income economy, we compute the ratio of the average public wage to GDP per working age population, (15 years old and over). In 1925, it was 1.2 in France, versus 8.6 in the colonies (Table 5, line 4). This ratio was particularly high in Indochina (14.8) and in West and Central Africa (7.4), lower in North Africa (4.3) and Madagascar (4.5). Overall, civil service wages in the colonies were seven times higher than in France when expressed in terms of GDP per worker, and the number of civil servants per capita was almost six times lower than in France. Under the doctrine of colonial self-financing, the level of wages severely restricted the volume of public service.

Of course, average public wages were high because of the presence of well-paid expatriate civil servants, as already noted by Huillery (2014) for AOF and by Frankema (2011) for British Africa. Before World War II, the colonial civil service had three wage schedules: 1) "European" or "Metropolitan", 2) "federal" or "common", and 3) "local". These schedules referred to the capacity to exert functions in 1) all territories including France, 2) within a federation (AOF, AEF or Indochina), 3) in a given colonial territory only. Before World War II, the Metropolitan schedule was reserved for French citizens. For a given nominal position, the base wage could be 20 to 50 percent lower in the local schedule. ${ }^{34}$ It is hard to evaluate what were, in this wage gap, the respective shares of racial discrimination on the one hand, and differences in training and skills on the other hand. Indeed, positions carrying the same name (for example, "teacher $2^{\text {nd }}$ class") nonetheless implied different exams and degrees in each schedule.

On top of the gap in base wages, French civil servants received bonuses meant to compensate for expatriation. These could be very high, from 25 to 70 percent of gross wage, depending on the territory and/or the period. To these bonuses were added a variety of allowances for remoteness, riskiness, housing, family charges and cost of living. In Algeria and after World War I in Tunisia, French settlers hired locally also received a 30 percent wage bonus ("tiers colonial"), even when they were born in Algeria and did not suffer from homesickness.

\footnotetext{
${ }^{34}$ One example is provided for teachers in Togo by Gbikpi-Benissan, (2011, vol. 2, p. 203).
} 
Though wage bonuses paid to French citizens were lower in the settlement colonies, their share in public employment was higher. In North Africa, autochthons made no more than 50 percent of civil servants, concentrated in low-skill and low-rank positions. ${ }^{35}$ Among French civil servants, the share born in North Africa varied greatly depending on the territory and the date considered (higher in Algeria, lower in Morocco especially in the early years). In Indochina and Madagascar, whose budgets allow breaking down public employment by citizenship, the French represented respectively 12 and 11 percent of public employment in 1925, and the shares were similar in 1943/46 (see Online Appendix II, Table A2.1). Available evidence suggests that the same proportion applied to West and Central Africa. ${ }^{36}$

From a detailed analysis of public employment and wages by citizenship in Indochina and Madagascar (presented in Online Appendix II) it appears that bonuses were set to keep French public wages in line with the earnings of settlers in the private sector, in order to attract sufficiently skilled candidates. It also seems that the high wages paid to French civil servants were pulling the autochthonous wage schedule upwards, because increasing inequality in pay too much was politically difficult (see Appendix II). In skilled occupations like teachers, some allowances were extended to autochthons.

Between 1925 and 1955, public expenditure measured in 1937 francs boomed, and public employment per 1,000 inhabitants roughly doubled everywhere. It increased from 11.8 to 21.6 in France, and from 2.2 to 4.6 on average in the empire. Wage dualism, however, remained high.

The official distinction between citizens and subjects was abolished in the 1940s. The three pre-war wage schedules mentioned above were renamed "general", "superior" and "local", to withdraw references to race, origin or place of recruitment that were now explicitly forbidden by law. ${ }^{37}$ Consequently, data on the composition of employment by citizenship is much more difficult to reconstruct. Despite the official end of discriminatory practices, the

${ }^{35}$ In 1921 Tunisia, more than 5,000 European civil servants were enumerated in the population census, while in our data for 1925 total public employment is around 10,000 (Régence de Tunis, Statistique générale de la Tunisie 1925, pp.8-9). In 1925 Tunisia, 35\% of teachers were from Metropolitan France, 44\% were French settlers recruited locally, and only $21 \%$ were Autochthons (Min. des Aff. Etrangères. Rapport au president de la République sur la situation de la Tunisie en 1925, p. 47). In 1936 Algeria, according to the population census Europeans made $62 \%$ of workers in the civil service and the army (Gouv. Gal de l'Algérie, Annuaire Statistique de l'Algérie 1939-1947, p.26).

${ }^{36}$ In 1926 Togo, African primary school teachers and lower rank instructors made 88\% of education personnel (68\% if we restrict to teachers): Gbikpi-Benissan (2011, pp. 217-218). In 1938 Cameroon, 595 French men are enumerated in civil service, according to a census (Ministère de la France d'Outre-Mer, 1947. Annuaire Statistique du Cameroun 1938-1945, volume I. Paris : Imprimerie Nationale, Tableau VIII p. 33). In our data, total public employment is 5,097, so that Autochthons again make $88 \%$ of total.

${ }^{37}$ See for instance: République Française, Loi $\mathrm{n}^{\circ}$ 50-772 du 30 juin 1950 . Of course in practice, even if not in law, these categories still correlated with race or origin. 
figures we could gather suggest that the civil service barely Africanized, even in North Africa where the room for progress was the largest. ${ }^{38}$

At the same time, wage bonuses decreased significantly. In Madagascar and in West and Central Africa after 1950, executives in the upper-tier, most often from France, saw their 70 percent bonus reduce to 40 percent. ${ }^{39}$ This adjustment was made easier by the fact that a large part of the top administration had been faithful to Vichy France and was wiped out and replaced after $1944 .^{40}$

One might expect that the reduction in bonuses and the hiring of more autochthons decreased wage dualism, but this was not the case. Everywhere, public wages increased faster than GDP per working age population, and wage dualism increased. ${ }^{41}$ While average real public wages were multiplied by 1.8 in France, they were multiplied by 2.0 in North Africa, 2.2 in Madagascar and almost tripled (2.8) in West and Central Africa. There, the increase in wage dualism was particularly striking, from 7.4 to 10.5 (Table 5).

In sub-Saharan Africa, a minor part of this increase in wage dualism can be accounted for by the change in the sectoral composition of autochthonous employment (mentioned in the previous section) from low-skill, low-pay jobs in security toward higher-skill, higher-pay jobs in education or health. ${ }^{42}$ Apart from this, the introduction of a new currency largely accounts for the higher increase in real wages, especially in AOF. Before 1945, France and its African colonies shared the same currency, the franc. During World War II, inflation had been lower in West and Central Africa than in France (see the "Prices" section in the Data Appendix). This inflation differential motivated the creation of the CFA franc in December 1945. In all sub-Saharan African colonies, including Madagascar, the currency was renamed "CFA franc" and its exchange rate with the French franc fixed at 1.7 (1946-47) then 2.0 (starting in

${ }^{38}$ For 1955, Amin (1966) reports 64,000 non-Muslim civil servants out of 95,000 in Algeria (p.153), 18,000 over 30,000 in Tunisia (p. 161), and 41,000 over 68,000 in Morocco (p. 174), i.e. respectively 67, 60 and $60 \%$. In 1945 Morocco, $71 \%$ of primary school teachers were French, 59\% in 1955 on the eve of independence (Roy. du Maroc, Tableaux économiques du Maroc 1915-1959, p. 37). In the school year 1962-63, just after Algeria's independence and the departure of many French settlers, "foreigners" still made $41 \%$ of all teachers from primary to senior secondary level (Office National des Statistiques de l'Algérie, Rétrospective 1962-2011, p.121, Table 4, http://www.ons.dz/-Retrospective-1962-2011-.html).

${ }^{39}$ See, for instance, République Française, Décret n 51-511 du 5 mai 1951.

40 On the Vichy period, see Cantier and Jennings (2004, especially pp. 334-363 on the aftermath of Vichy). On the replacement of colonial governors, see Chambru and Viallet-Thévenin (2017).

${ }^{41}$ The decrease in the Empire's average is only due to the fact that data are missing for Indochina in 1955.

${ }^{42}$ When using the breakdown of public employment by administrative sector, the Fisher index of wages (geometric mean of the Laspeyres and Paasche indexes) increases slightly less than the average wage, pointing to more frequent recruitment in high-pay sectors; correspondingly the Fisher index of employment increases more than total public employment. This is especially true in AEF and Cameroon, and secondarily in Madagascar. 
1948). ${ }^{43}$ In 1948, the new exchange rate compensated for the differences in price levels. One exception was Madagascar, where inflation during the war had been high. This was still true in 1955 AOF and Togo, less true in AEF and Cameroon where inflation was higher in 19491955. When the new currency was introduced, nominal wages were not changed, but they were now paid in CFA francs rather than in French francs, so that wages in French francs suddenly increased. Between 1948 and 1955 public wages were subject to the same proportional increases in nominal terms as in France. Such measures were meant to increase real wages after they had been eroded by World War II inflation (Piketty 2018 pp. 191-194). Between 1937 and 1955, the inflation differential alone generated large gains in real wages in sub-Saharan Africa, around 57 percent in AOF and Togo, 25 percent in AEF and Cameroon, but not much in Madagascar. Furthermore, the creation and appreciation of the CFA franc preserved the purchasing power of these wages in France or in terms of French imports. ${ }^{44}$

As bonuses for French citizens decreased, as the skill-composition of autochthonous employment improved, and as African trade unions demanded more equality in pay (Cooper, 1996, pp. 277-322 and pp. 407-431), one could expect to see a compression of the public wage distribution, but this is hard to see in the absence of detailed data. ${ }^{45}$ This kind of compression is observed in 1945 Indochina and Madagascar (compared to 1925), between average French wages and average autochthons' wages (see Online Appendix II).

Overall, public wages remained high in the French colonies after World War II, and they remained high when the colonies obtained their independence around 1960. Authors including Samir Amin (1966) on North Africa and René Dumont (1962) on sub-Saharan Africa underlined, in the early 1960s, the high level of public wages in newly independent states. Both criticized the one-to-one replacement of French civil servants at the same wage. ${ }^{46}$ It is not to say that paying civil servants well was necessarily a bad thing, as we cannot analyze the correlation of wages with productivity. Yet, the colonial legacy of wage dualism very much

${ }^{43}$ North African colonies kept the franc until their independence, like Indochina with the piaster. Guinea left the franc zone in 1960; Mali left only for the period between 1962 and 1984; and Madagascar left in 1973. The exchange rate of CFAF remained constant until its devaluation by 50\% in 1994.

${ }^{44}$ During the war, inflation was higher in North Africa than in France. As of 1955, the difference in CPI had been erased in Algeria, but preserved in Tunisia and Morocco, where real wages therefore remained more depressed, by 19 percent to 26 percent, according to our coarse estimates (see Data Appendix).

${ }^{45} \mathrm{We}$ collected for each territory the wages of lowest- and highest-paid teachers and nurses, at six dates between 1913 and 1955. These series are particularly noisy, and from them we cannot identify any time trend on the range of variation of wages in those two occupations.

46 The extent to which wage dualism persisted in independent countries is not the object of this paper. Present-day estimates suggest that wage dualism is still high in former French Africa, even after the CFA franc devaluation of 1994 (Bossuroy and Cogneau 2013). Our research on British and French colonies of West Africa (Cogneau, Dupraz and Mesplé-Somps 2018) suggests that average public wages remained high in former French West Africa but were allowed to decrease in former British West Africa. 
determined the features of socioeconomic and political inequalities in the young independent countries. In their first two decades of existence, an administrative bourgeoisie emerged, a "bourgeoisie of the civil service" in the words of Franz Fanon (1961) - see also Simson (2017, 2018). The combined economic affluence and political influence of this group led to the entrenchment of patron-client relationships with the rest of society. Just after independence, the legitimacy of this new social class was high. However, its initial political capital depreciated and its authority was undermined because socioeconomic and political dualism persisted, and because development was not shared.

\section{Conclusion}

Colonial states of the French empire had high extractive efficiency, but low productive efficiency. Largely self-financed before 1945, they taxed a lot, adapting their fiscal tools to different socioeconomic contexts and varying historical conditions, but they were not very productive in service provision, notably because of the very high wage costs coming with the employment of expatriated French civil servants. Their public expenditure was also biased toward the interests of a small enclave of French settlers and French firms. Their low productive efficiency meant they were not omnipotent leviathans; their high extractive efficiency means they were not casual night watchmen either.

After World War II, as the legitimacy of French rule was increasingly questioned, colonial governments did not tax and spend less; on the contrary, they taxed and spent more. In the hope of preserving their imperial dominance, they accelerated their modernization project and became more developmental. They increased their social spending, notably in education. They gave some political rights to local populations, extending voting franchise to those under their rule who had been excluded. They adopted somewhat more progressive taxes, and conceded some wage equality claims. The self-financing doctrine was relaxed, and net grants from Metropolitan France started representing a larger share of the colonies' GDP. Wage costs, however, remained high. Wage dualism, measured as the ratio of average public wage to GDP per working population, increased between 1925 and 1955. Given these high unit costs, accelerating development would probably have required an even bigger push in French grants

Independent states inherited the structures of colonial states. In particular, they inherited dualism: dualistic societies and economies, with the existence of formal, France-like enclaves benefitting from high-quality public services in a largely informal and traditional society 
starting to demand more equality in service provision; and dualistic wage structures, with public wages set at very high standards in comparison to domestic income levels. The departure of settlers and colonial administrators paved the way for their replacement by a bourgeoisie of the civil service. Not all countries followed the same paths or had the same speed or characteristics in terms of reforms that veered between radical breaks and neocolonial continuities. Some preserved high wages and elitist infrastructure. Others opted instead to extend public employment and decentralize at lower costs. Further research is warranted to analyze these postcolonial evolutions. 


\section{References}

Adelman, Irma and Cynthia Taft Morris. "Editorial: Development history and its implications for development theory", World Development 25, n6 (1997): 831-840.

Ageron, Charles-Robert. Histoire de l'Algérie Contemporaine. Tome II : De l'insurrection de 1871 au déclenchement de la guerre de libération. Paris: PUF, 1979.

Alvaredo, Facundo, Denis Cogneau and Thomas Piketty. "Income Inequality under Colonial Rule. Evidence from French Algeria, Cameroon, Indochina and Tunisia, 1920-1960", PSE working paper, 2017.

Amin, Samir. L'économie du Maghreb. La colonisation et la décolonisation. Paris: Editions de Minuit, 1966.

Amsden, Alice. The Rise of "The Rest": Challenges to the West from Late-Industrializing Economies, Oxford University Press, 2001.

Bassino, Jean-Pascal. "Preliminary Estimates of Vietnam GDP 1800-1970: North-South Economic Divide in Historical Perspective." In Constructing a Historical Macroeconomic Database for the Trans-Asian Regions, edited by Konosuke, Odaka, Kyokawa, Yukihiko, and Kuboniwa, Masaaki, 9-41. Tokyo: Institute of Economic Research, Hitotsubashi University, 2000.

Bassino, Jean-Pascal, Jean-Dominique Giacometti and Konosuke Odaka (eds). Quantitative Economic History of Vietnam 1900-1990. An International Workshop, Nishi-Futsu Kaikan /Maison Franco-Japonaise, Tokyo. Institute of Economic Research, Hitotsubashi University, 2000.

Bayart, Jean-François. The State in Africa. The Politics of the Belly, London: Longman, 1993.

Bernard, François. "Le régime douanier colonial”, Revue d'économie politique 27, n4 (1913) : 450-461.

Besley, Timothy and Torsten Persson. "The Origins of State Capacity: Property Rights, Taxation, and Politics", American Economic Review, 99, n 4 (2009): 1218-1244.

University Press, 2011.

Boeke, Julius H. Economics and economic policy of dual societies, as exemplified by Indonesia. New York: International Secretariat, Institute of Pacific Relations, 1953.

Booth, Anne. Colonial Legacies: Economic and Social Development in East and Southeast Asia, University of Hawaii Press, 2007.

Bossuroy Thomas and Denis Cogneau. "Social Mobility in Five African Countries". Review of Income and Wealth, 59, $\mathrm{n}^{\circ} \mathrm{S} 1$ (2013): 84-110.

Bouveresse, Jacques. Un Parlement colonial? Les délégations financières algériennes (18981945). Rouen: Presses universitaires de Rouen, 2008.

Brunschwig, Henri. Mythes et réalités de l'impérialisme colonial français, Paris : Armand Colin, 1960.

Campbell, Gwynn. An Economic History of Imperial Madagascar 1750-1895. The Rise and Fall of an Island Empire, Cambridge: Cambridge University Press, 2005.

Cantier, Jacques, et Eric Jennings (dir.). L'Empire colonial sous Vichy, Paris: Odile Jacob, 2004. 
Chambru, Cédric et Scott Viallet-Thévenin. «Mobilité sociale et empire colonial: les gouverneurs coloniaux français entre 1830 et 1960 », mimeo, Université de Genève, 2017.

Cogneau, Denis and Alexander Moradi. "Borders that Divide: Education and Religion in Ghana and Togo since Colonial Times", Journal of Economic History, 74, n³ (2014): 694728.

Cogneau, Denis, Yannick Dupraz and Sandrine Mesplé-Somps. "African states and development in historical perspective: Colonial public finances in British and French West Africa." PSE Working Papers n²018-29, 2018.

Collot, Claude. Les institutions de l'Algérie durant la période coloniale (1830-1962). Paris: CNRS \& Alger: Office des publications universitaires, 1987.

Cooper, Fredrick. Decolonization and African Society. The labor question in French and British Africa, Cambridge University Press, 1996.

Press, 2002.

Africa since 1940: The Past of the Present, Cambridge: Cambridge University 2014a.

Africa in the World. Capitalism. Empire. Nation-State, Harvard University Press,

. Citizenship between Empire and Nation. Remaking France and French Africa 1945-1960, Princeton University Press. French edition: Français et Africains? Etre citoyen au temps de la décolonisation, Paris : Payot, 2014b.

Cornevin, Robert. «La France d'Outre-Mer», in Alfred Sauvy, Histoire économique de la France entre les deux guerres, tome 3 («Diverse sujets »), chapitre XI pp. 267-308, Paris : Fayard, 1972.

Dincecco, Mark. "The Rise of Effective States in Europe", Journal of Economic History 75 n³ (2015): 901-917.

Dumont, René. False Start in Africa. New York: Frederick A. Praeger, 1966. French edition: L'Afrique Noire est mal partie, Paris: Seuil, 1962.

Dupraz, Yannick. "French and British Colonial Legacies in Education: Evidence from the Partition of Cameroon", Journal of Economic History, forthcoming, 2019.

Fall, Babacar. Le travail forcé en Afrique occidentale française (1900-1946). Paris : Karthala, 1993.

Fanon, Frantz. Les damnés de la terre, Paris: Maspero, 1961.

Frankema, Ewout. "Raising revenue in the British empire, 1870-1940: how 'extractive' were colonial taxes?" Journal of Global History, 5, n³ (2010): 447-477.

. "Colonial taxation and government spending in British Africa, 1880-1940: Maximizing revenue or minimizing effort?” Explorations in Economic History, 48, ${ }^{\circ} 1$ (2011): 136-149.

Frankema, Ewout and Marlous van Waijenburg. "Structural Impediments to African Growth? New Evidence from British African Real Wages, 1880-1965", Journal of Economic History 72, n4 (2012): 895-926.

."Metropolitan Blueprints of Colonial Taxation? Lessons from Fiscal Capacity Building in British and French Africa, 1880-1940." Journal of African History 55, n³ (2014): 371-400. 
Frémeaux, Jacques. Les colonies dans la Grande Guerre, Paris : Editions 14-18, 2006.

Fremigacci, Jean. Etat, économie et société coloniale à Madagascar (De la fin du XIXè siècle aux années 1940). Paris: Karthala, 2014.

Gardner, Leigh A. Taxing Colonial Africa: The Political Economy of British Imperial Rule, Oxford University Press, 2012.

Gbikpi-Benissan, François. Le système scolaire au Togo sous mandat français, Paris: L'Harmattan, 2011.

Gerschenkron, Alexander. Economic Backwardness in Historical Perspective: A Book of Essays, Harvard University Press, 1962.

Herbst, Jeffrey. States and Power in Africa: Comparative Lessons in Authority and Control, Princeton University Press, 2000.

Hoffman, Philip T. "What Do States Do? Politics and Economic History." Journal of Economic History 75, $\mathrm{n}^{\circ} 2$ (2015): 303-332.

Huillery, Elise. "The Black Man's Burden: The Cost of Colonization of French West Africa”, Journal of Economic History, 74, ${ }^{\circ} 1$ (2014): 1-38.

Jacob, Guy. "Gallieni et " l'impôt moralisateur » à Madagascar. Théorie, pratiques et conséquences (1901-1905)", Revue française d'histoire d'outre-mer 74, n²77 (1987): 431473.

Jedwab, Rémi and Alexander Moradi. "The Permanent Effects of Transportation Revolutions in Poor Countries: Evidence from Africa", Review of Economics and Statistics, 89, n² (2016): 268-284.

Kateb, Kamel. "Les séparations scolaires dans l'Algérie coloniale", Insanyat, Revue algérienne d'anthropologie et de sciences sociales, 25-26 (2004): 65-100.

Law, Robin (ed.). From Slave Trade to 'Legitimate' Commerce. The commercial transition in nineteenth-century West Africa. Cambridge University Press, 1995.

Lewis, W. Arthur. "Economic Development with unlimited Supplies of Labour." The Manchester School 22, n² (1954): 139-91.

Lindert, Peter. Growing Public: Social Spending and Economic Growth Since the Eighteenth Century, 2 vol., Cambridge University Press, 2004.

Marseille, Jacques. Empire colonial et capitalisme français. Histoire d'un divorce. Paris : Albin Michel, 1984 [2 $2^{\text {nd }}$ edition 2005].

Nicolaï, André. “Tunisie : fiscalité et développement”, Tiers-Monde 3, n¹1 (1962) : 429-478.

Peres-Cajías, José Alejandro. "The expansion of public spending and mass education in Bolivia: did the 1952 Revolution represent a permanent shock?", in Bértola, L. and Williamson, J. (eds.) Has Latin American inequality changed direction? Looking over the long run. New York: Springer, pp. 195-218, 2017.

Piketty, Thomas. Top Incomes in France in the Twentieth Century, Cambridge MA: Harvard University Press, 2018.

Reid, Richard J. A History of Modern Africa, 1800 to Present. Wiley-Blackwell, 2012.

Saul, Samir. Intérêts économiques français et décolonisation de l'Afrique du Nord (19451962), Genève : Librairie Droz, 2016. 
Simson, Rebecca. "Africa's clientelist budget policies revisited: public expenditures and employment in Kenya, Tanzania and Uganda 1960-2010”, Economic History Review, 2018.

. "The rise and fall of Africa's bureaucratic bourgeoisie: public employment and the income elites of postcolonial Kenya and Tanzania", LSE International Inequalities Institute Working paper 10, 2017.

Sokoloff, Kenneth L. and Eric M. Zolt. "Inequality and the Evolution of Institutions of Taxation: Evidence from the Economic History of the Americas", in Sebastian Edwards, Gerardo Esquivel \& Graciela Márquez (eds), The Decline of Latin American Economies: Growth. Institutions. and Crises, University of Chicago Press, 2007.

Sraieb, Noureddine. "L'idéologie de l'école en Tunisie coloniale (1881-1945)", Revue du monde musulman et de la Méditerranée, 68-69 (1993): 239-254.

Tilly, Charles. Coercion, Capital, and European States, AD 990-1992, London: Basil Blackwell, 1990.

Valensi, Lucette. Le Maghreb d'avant la prise d'Alger. Paris: Flammarion, 1969.

van Waijenburg, Marlous. "Financing the African Colonial State: The Revenue Imperative and Forced Labor", Journal of Economic History, 78, n¹ (2018):40-80.Weil, Patrick. "Le statut des musulmans en Algérie coloniale. Une nationalité française dénaturée", Histoire de la justice 16, $\mathrm{n}^{\circ} 1$ (2005): 93-109.

Young, Crawford. The African Colonial State in Comparative Perspective, New Haven: Yale University Press, 1995.

Zucarelli, François. "De la chefferie traditionnelle au canton : évolution du canton colonial au Sénégal - 1855-1960”, Cahiers d'Etudes africaines 50 (1973): 213-238. 
Figure $1-$ Colonial territories present in our data

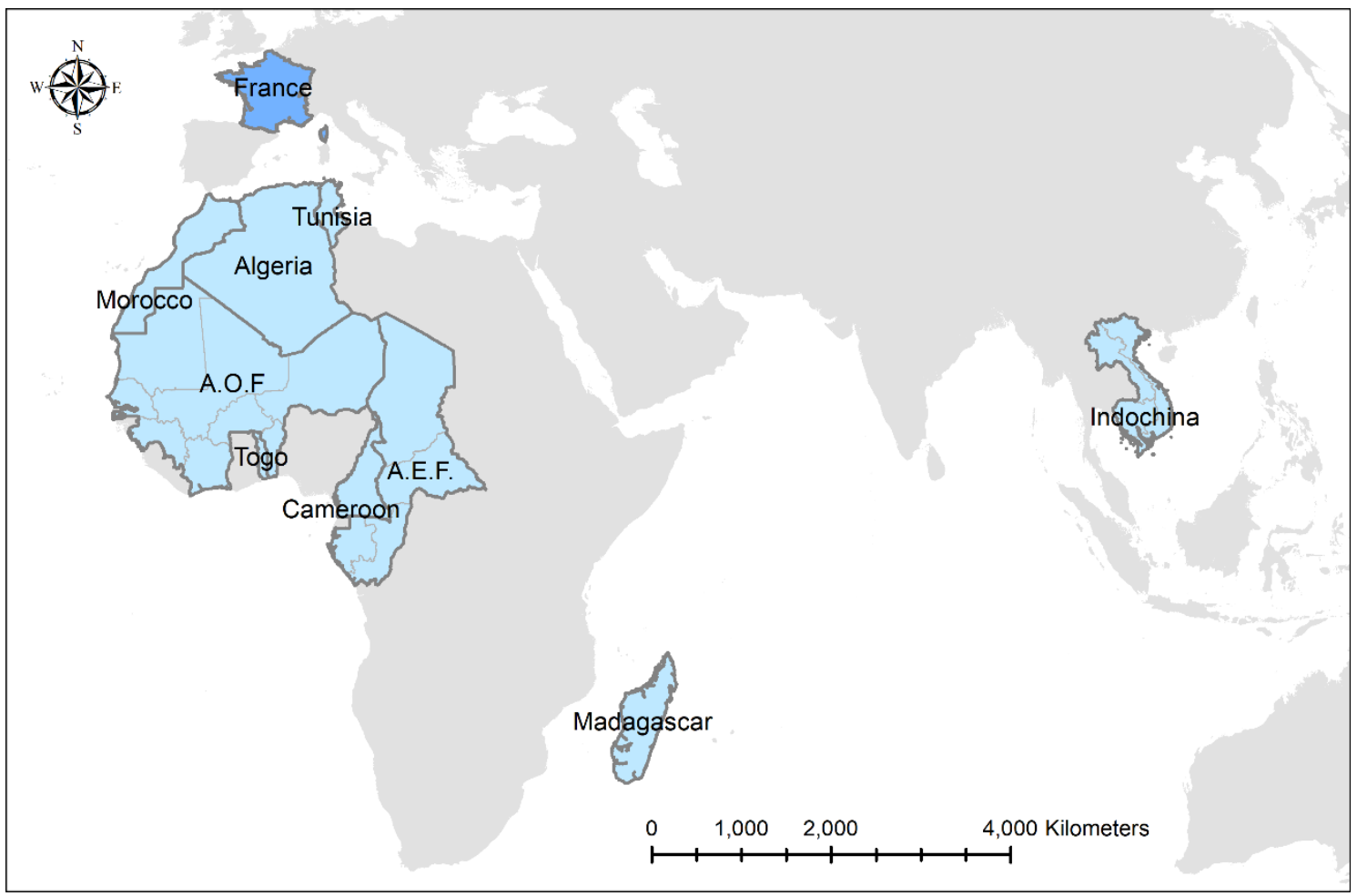

Table 1 - Population, urbanization and GDP in France and its empire, 1850, 1925 and 1955

\begin{tabular}{|c|c|c|c|c|c|c|}
\hline & & France & $\mathrm{NA}$ & Indochina & Madag. & WCA \\
\hline \multirow{3}{*}{$\begin{array}{l}\text { Population in } \\
\text { millions }\end{array}$} & 1850 & 36.2 & 9.0 & 14.2 & 2.2 & 15.2 \\
\hline & 1925 & 40.5 & 13.7 & 26.1 & 3.6 & 21.3 \\
\hline & 1955 & 43.4 & 22.4 & 34.6 & 4.9 & 34.0 \\
\hline \multirow{3}{*}{$\begin{array}{l}\text { Share of } \\
\text { Europeans (\%) }\end{array}$} & 1850 & & 1.6 & $\varepsilon$ & $\varepsilon$ & $\varepsilon$ \\
\hline & 1925 & & 8.1 & 0.1 & 0.5 & 0.1 \\
\hline & 1955 & & 7.0 & 0.0 & 1.2 & 0.4 \\
\hline \multirow{3}{*}{ Urbanisation } & 1850 & $25.5 \%$ & $6.6 \%$ & $1.4 \%$ & $2.2 \%$ & $0.7 \%$ \\
\hline & 1925 & $48.8 \%$ & $16.4 \%$ & $2.1 \%$ & $4.7 \%$ & $1.4 \%$ \\
\hline & 1955 & $56.0 \%$ & $24.3 \%$ & $12.0 \%$ & $9.0 \%$ & $12.1 \%$ \\
\hline \multirow{2}{*}{$\begin{array}{l}\text { GDP per capita } \\
\text { (1937 FF PPP) }\end{array}$} & 1925 & 8,776 & 1,811 & 623 & 782 & 546 \\
\hline & 1955 & 13,879 & 2,383 & 469 & 1,137 & 902 \\
\hline
\end{tabular}

\footnotetext{
Notes: NA: North Africa; WCA: West and Central Africa. Sources: see Data Appendix and also Appendix I on
} urbanization. 
Table 2 - Fiscal extraction and state size across the French empire in 1925, 1955 and 2010

\begin{tabular}{|c|c|c|c|c|c|c|}
\hline \multirow[b]{2}{*}{ Year 1925} & \multirow[t]{2}{*}{ France } & \multirow[t]{2}{*}{ Empire } & \multirow[t]{2}{*}{ NA } & \multirow[t]{2}{*}{ Indoch. } & \multirow[t]{2}{*}{ Madag. } & \multirow[t]{2}{*}{ WCA } \\
\hline & & & & & & \\
\hline Net Public Revenue / GDP (\%) & 16.5 & 8.9 & 8.3 & 12.5 & 9.0 & 5.4 \\
\hline Central gov. Tax Revenue / GDP (\%) & 11.1 & 4.8 & 3.9 & 6.0 & 7.3 & 4.5 \\
\hline Net Public Exp. (civilian) / GDP (\%) & 8.0 & 8.0 & 7.9 & 10.9 & 7.5 & 4.4 \\
\hline NPE (civilian) per capita (1937 FF) & 703 & 69 & 143 & 68 & 59 & 24 \\
\hline French military exp. per cap. (1937 FF) & 334 & 28 & 107 & 7 & 13 & 6 \\
\hline \multicolumn{7}{|l|}{ Year 1955} \\
\hline Net Public Revenue / GDP (\%) & 26.3 & 15.9 & 19.1 & 9.5 & 14.6 & 13.9 \\
\hline with social security transfers & 33.4 & 17.1 & 21.5 & 9.5 & 14.6 & 13.9 \\
\hline Central gov. Tax Revenue / GDP (\%) & 19.0 & 9.6 & 10.0 & 5.4 & 6.7 & 11.8 \\
\hline Net Public Exp. (civilian)/ GDP (\%) & 23.1 & 19.1 & 24.1 & 7.6 & 18.5 & 16.6 \\
\hline NPE (civilian) per capita (1937 FF) & 3,210 & 211 & 575 & 36 & 210 & 150 \\
\hline French military exp. per cap. (1937 FF) & 1,034 & 145 & 170 & 257 & 63 & 26 \\
\hline \multicolumn{7}{|l|}{ Year 2010} \\
\hline Net Public Revenue / GDP (\%) & 25.2 & 26.3 & 31.8 & 22.7 & 11.2 & 18.8 \\
\hline with social security transfers & 43.3 & 30.1 & 37.2 & 26.9 & 11.2 & 19.2 \\
\hline NPR / GDP, non-mineral (\%) & 25.2 & 20.6 & 22.1 & 21.7 & 11.2 & 15.3 \\
\hline Tax Revenue / GDP, non-mineral (\%) & 25.2 & 18.0 & 19.6 & 19.3 & 9.2 & 13.8 \\
\hline
\end{tabular}

Notes: NA: North Africa; WCA: West and Central Africa. North Africa 1925: data for Morocco is from 1926. Indochina 1955: data from 1953 (1954 for the PMS region). Madagascar 1955: data from 1956. WCA 1955: data for AEF is from 1954, data for Togo from 1956. 2010: authors' calculations from WDI data (https://data.worldbank.org/data-catalog/world-development-indicators), IMF Article 4 Consultations (https://www.imf.org/external/np/sec/aiv/index.aspx?listby=c) and ILO Social Security Inquiry database (https://www.ilo.org/dyn/ilossi/ssimain.home). In 1925, there was no social security in the colonies, and social security transfers represented $0.05 \%$ of GDP only in Metropolitan France. 
Figure 2 - Net public revenue as share of GDP from 1890 to 1970

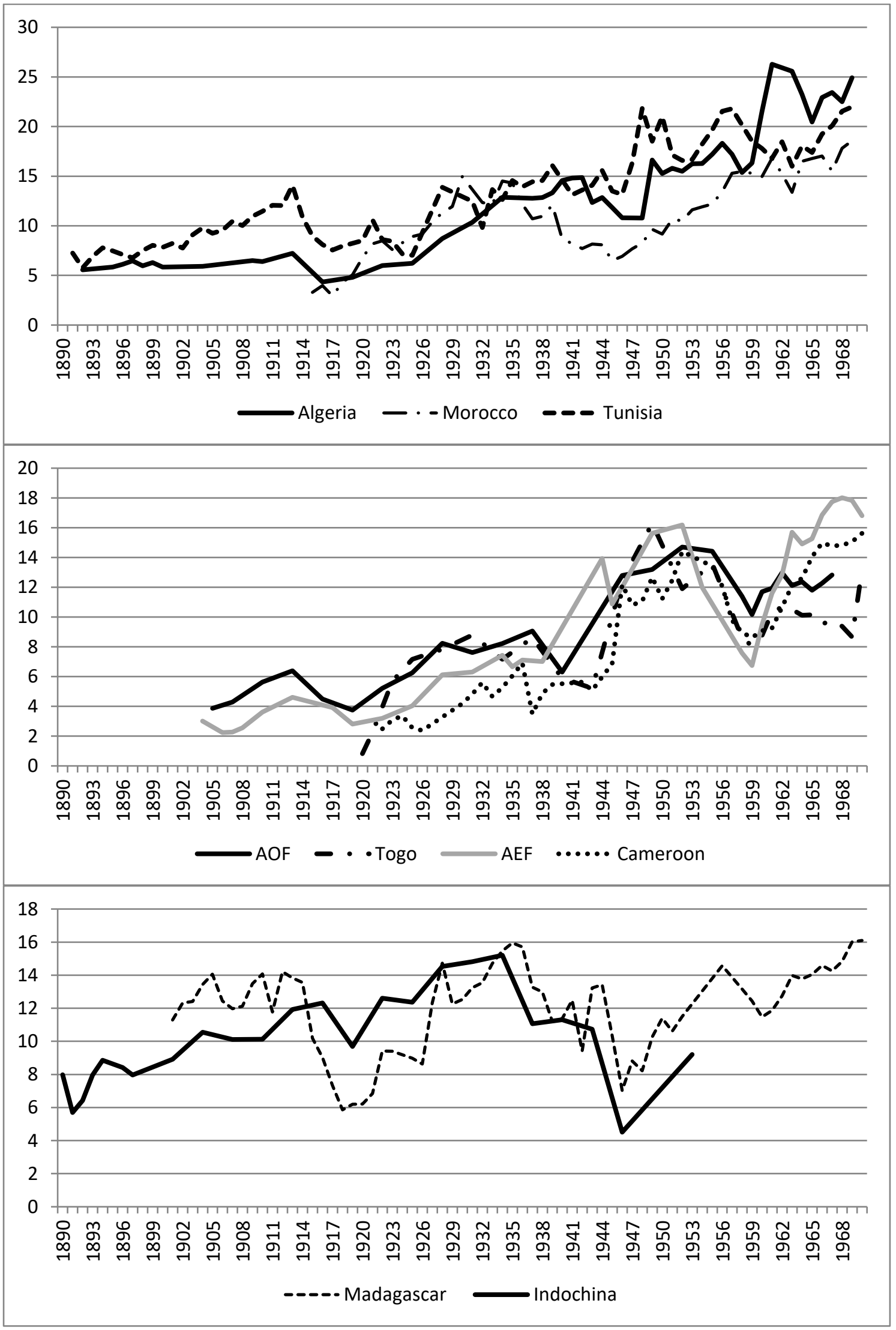

Notes. The revenue of first-level administrative divisions (provinces, départements, régions) is included and consolidated, but not the revenue of second-level administrative divisions (municipalities). See Data Appendix. 
Table 3 - Share of different tax instruments in GDP (\%), 1925 and 1955

\begin{tabular}{|c|c|c|c|c|c|c|}
\hline \multirow[b]{2}{*}{ Year 1925} & \multirow[t]{2}{*}{ France } & \multirow[t]{2}{*}{ Empire } & \multirow[t]{2}{*}{ NA } & \multirow[t]{2}{*}{ Indoch. } & \multirow[t]{2}{*}{ Madag. } & \multirow[t]{2}{*}{ WCA } \\
\hline & & & & & & \\
\hline Capitation & 0.00 & 0.97 & 0.08 & 1.62 & 2.91 & 1.52 \\
\hline Monopolies & 1.85 & 2.41 & 2.21 & 4.22 & 1.40 & 0.55 \\
\hline Intermediate \& Other & 6.91 & 2.97 & 2.53 & 4.86 & 2.39 & 1.40 \\
\hline Trade & 0.77 & 1.50 & 1.22 & 1.49 & 2.28 & 1.95 \\
\hline Modern direct \& indirect & 4.38 & 0.58 & 1.18 & 0.19 & 0.00 & 0.00 \\
\hline Total & 13.92 & 8.44 & 7.21 & 12.37 & 8.97 & 5.43 \\
\hline \multicolumn{7}{|l|}{ Year 1955} \\
\hline Capitation & 0.00 & 0.71 & 0.01 & 0.04 & 2.56 & 1.96 \\
\hline Monopolies & 1.70 & 2.98 & 4.22 & 1.99 & 2.13 & 1.50 \\
\hline Intermediate \& Other & 6.94 & 3.92 & 4.84 & 2.68 & 2.67 & 3.21 \\
\hline Trade & 1.84 & 3.26 & 1.53 & 3.59 & 5.42 & 5.72 \\
\hline Modern direct \& indirect & 12.05 & 3.25 & 5.13 & 0.90 & 1.79 & 1.50 \\
\hline Total & 22.53 & 14.14 & 15.73 & 9.21 & 14.57 & 13.89 \\
\hline
\end{tabular}

\footnotetext{
Notes: NA: North Africa; WCA: West and Central Africa. See Data Appendix for the precise definition of each tax instrument. North Africa 1925: data for Morocco is from 1926. Indochina 1955: data is from 1953 (1954 for the PMS region). Madagascar 1955: data is from 1956. WCA 1955: data for AEF is from 1954, data for Togo is from 1956. The sum of all tax instruments does not sum to net public revenue / GDP as presented in table 2 because Table 2 takes revenue of municipalities into account, while this table considers only the revenue of the central government and first level administrative divisions.
} 
Figure 3 - Net grants from France as a share of GDP, 1890-1970

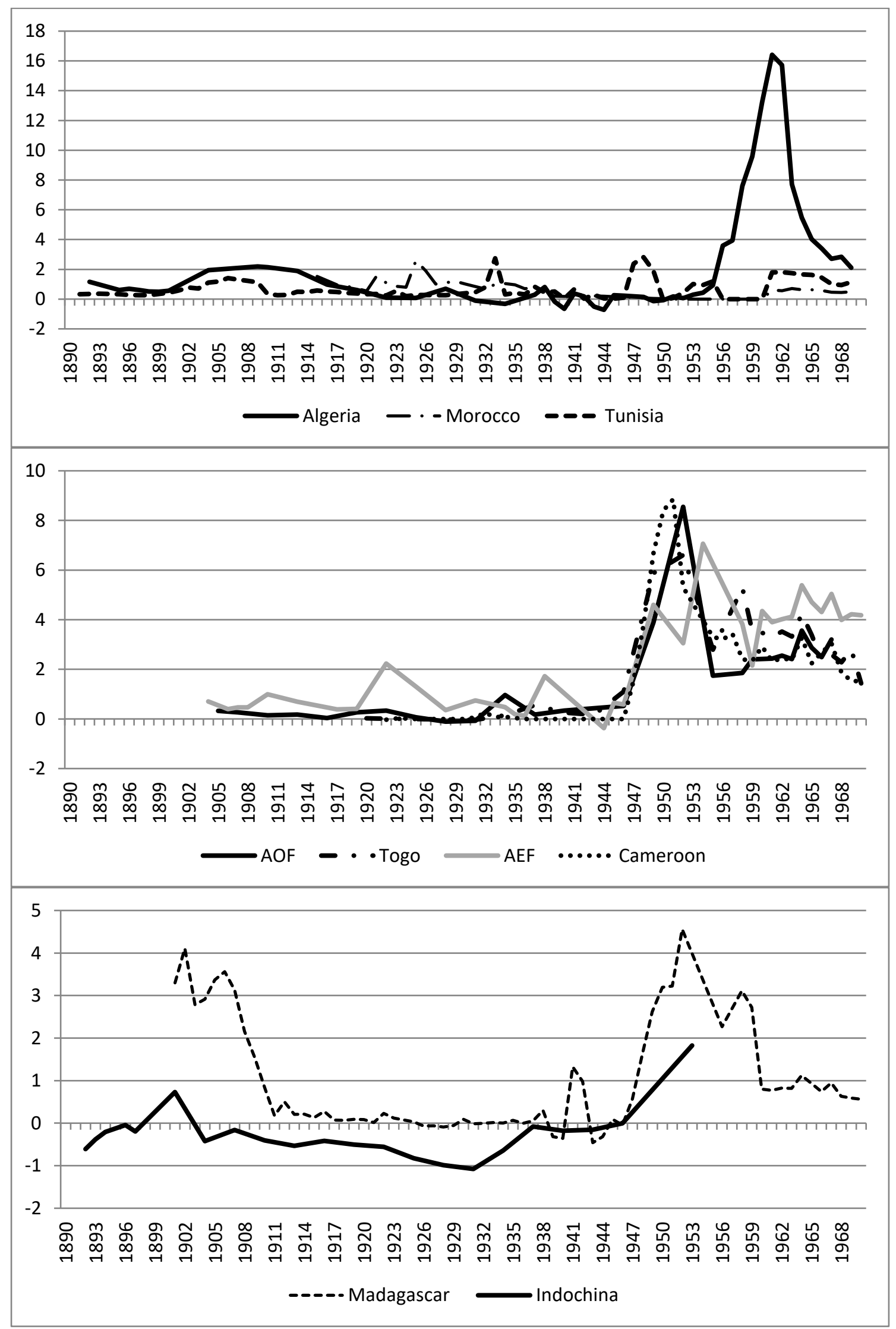

Notes. These are net grants from France, negative numbers mean the grants from the colony to France are larger than the grants from France to the colony (for instance Indochina 1905-1937). French military expenditure is not counted, except expenditure in infrastructure and health. See Data Appendix. 
Figure 4 - Public revenue, loans, grants and military expenditure as percentage of the Empire's GDP

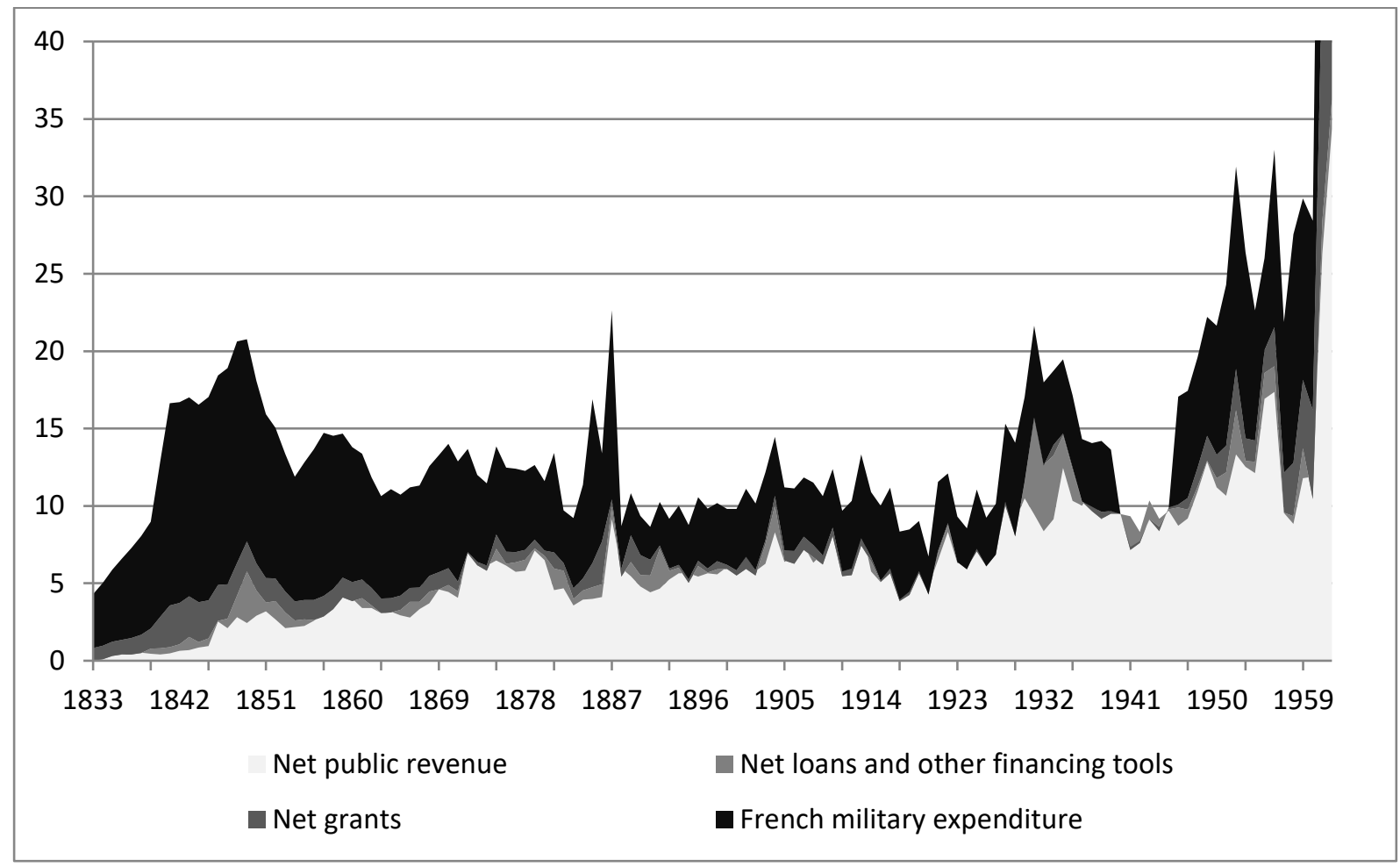

Notes. Sources are detailed in the Data Appendix. Civilian net grants include military expenditure in infrastructure and health. Military expenditure includes personnel and operating expenses of troops, and expenditure other than in infrastructure and health. French military expenditure in the colonies during World War II is missing. The military costs of the Indochinese and Algerian wars are rough estimates, likely to be underestimated in the case of Algeria. In federations, loans and grants were mostly managed by the federal budget, for which we have annual series; for net public revenue, our series are less frequent (see Data Appendix); missing years were extrapolated linearly. The boundaries of the colonial Empire change: for example, the last two years correspond to Algeria only. Years 1961 and 1962 are out of range, and should anyway be regarded with caution due to many data uncertainties linked to the Algerian crisis. 
Table 4 - Public expenditure and development outcomes in 1925 and 1955

\begin{tabular}{|c|c|c|c|c|c|c|}
\hline \multirow[b]{2}{*}{ Year 1925} & France & Empire & NA & Indoch. & Madag. & WCA \\
\hline & & & & & & \\
\hline \multicolumn{7}{|l|}{ Infrastructure \& production support } \\
\hline Share in expenditure $(\%)$ & 41.8 & 43.4 & 49.8 & 37.6 & 32.4 & 46.3 \\
\hline $\mathrm{kWh}$ per inhabitant & 318.5 & n.a. & $6.5^{\mathrm{a}}$ & n.a. & n.a. & n.a. \\
\hline Roads meters per 1000 inhabitants & 19.2 & n.a. & 1.0 & 0.9 & n.a. & n.a. \\
\hline Railroads meters per 1000 inhabitants & 1.1 & n.a. & 0.6 & 0.1 & n.a. & $0.2^{\mathrm{b}}$ \\
\hline \multicolumn{7}{|l|}{ Education } \\
\hline Share in expenditure $(\%)$ & 20.3 & 7.3 & 9.1 & 6.7 & 6.4 & 3.6 \\
\hline Gross primary enrollment, autochthons (\%) & 135.3 & 3.5 & 4.1 & 4.7 & n.a. & $1.7^{\mathrm{c}}$ \\
\hline Government schools only (\%) & 108.4 & n.a. & 3.8 & 4.2 & n.a. & n.a. \\
\hline \multicolumn{7}{|l|}{ Health } \\
\hline Share in expenditure $(\%)$ & 5.9 & 5.9 & 6.7 & 4.4 & 11.6 & 5.9 \\
\hline Public health personnel per 1000 inhabitants & 1.4 & 0.14 & $0.31^{\mathrm{a}}$ & 0.08 & 0.26 & 0.09 \\
\hline Medical staff per 1000 inhabitants & 1.27 & 0.04 & $0.15^{\mathrm{a}}$ & 0.02 & 0.08 & $0.03^{\mathrm{c}}$ \\
\hline \multicolumn{7}{|l|}{ Administration, Finance, Justice and Security } \\
\hline Share in expenditure $(\%)$ & 31.9 & 32.7 & 24.7 & 41.6 & 27.8 & 30.6 \\
\hline Share in employment $(\%)$ & 25.0 & 56.2 & 46.1 & 63.5 & 55.1 & 58.9 \\
\hline \multicolumn{7}{|l|}{ Year 1955} \\
\hline \multicolumn{7}{|l|}{ Infrastructure \& support to production } \\
\hline Share in expenditure $(\%)$ & 54.9 & 47.9 & 47.4 & 29.9 & 45.3 & 53.4 \\
\hline $\mathrm{kWh}$ per inhabitant & 1,148 & 39.5 & 91.0 & n.a. & 11.8 & 5.9 \\
\hline Roads meters per 1000 inhabitants & 15 & 4.7 & 5.0 & n.a. & 5.9 & 4.4 \\
\hline Railroads meters per 1000 inhabitants & 0.9 & 0.2 & 0.3 & n.a. & 0.2 & 0.1 \\
\hline \multicolumn{7}{|l|}{ Education } \\
\hline Share in expenditure $(\%)$ & 13.5 & 11.3 & 13.4 & 10.8 & 7.1 & 7.7 \\
\hline Gross primary enrollment, autochthons (\%) & 109.8 & 14.5 & 17.6 & n.a. & 32.2 & 12.4 \\
\hline Government schools only (\%) & 92.9 & 10.7 & 17.1 & n.a. & 20.9 & 6.4 \\
\hline \multicolumn{7}{|l|}{ Health } \\
\hline Share in expenditure $(\%)$ & 11.6 & 7.9 & 7.7 & 6.9 & 8.2 & 8.6 \\
\hline Public health personnel per 1000 inhabitants & n.a. & 0.58 & $0.65^{\mathrm{d}}$ & n.a. & 0.82 & 0.54 \\
\hline Medical staff per 1000 inhabitants & 1.97 & 0.30 & 0.29 & n.a. & 0.50 & 0.27 \\
\hline \multicolumn{7}{|l|}{ Administration, Finance, Justice and Security } \\
\hline Share in expenditure $(\%)$ & 15.8 & 23.2 & 24.6 & 41.6 & 16.4 & 17.4 \\
\hline Share in employment $(\%)$ & 25.9 & 42.6 & 47.4 & n.a. & n.a. & 38.5 \\
\hline
\end{tabular}

Notes: NA: North Africa; WCA: West and Central Africa. Expenditure shares: excluding the military, central government only in Metropolitan France, central government and first level administrative divisions in the colonies; NA 1925: Moroccan data from 1926; Indoch. 1955: data from 1953; Madag. 1955: data from 1956; WCA 1955: AEF data from 1954. Employment shares: excluding the military, for the central government only everywhere; NA 1925: Tunisian data from 1924; WCA 1925: Togolese data from 1926. Gross primary enrollment rates $=$ number of primary school pupils divided by the 6-13 year old population. They count only public and government-authorized private schools, not unofficial Koranic schools (which gathered 36,000 pupils in 1932 Algeria and 100,000 pupils in 1950 Algeria (Kateb, 2004), nor municipal schools in Indochina. In Tunisia and Morocco, Jewish children, who already enjoyed universal primary schooling like Europeans in 1925, are counted apart. a: Algeria and Morocco only. b: AOF only. c: AOF, Togo and Cameroon only. d: Tunisia only. 
Table 5 - Public Employment and Wages in 1925 and 1955

\begin{tabular}{|c|c|c|c|c|c|c|}
\hline \multirow[b]{2}{*}{ Year 1925} & France & Empire & NA & Indoch. & Madag. & WCA \\
\hline & \multirow[b]{2}{*}{470} & \multirow[b]{2}{*}{64} & \multirow[b]{2}{*}{124} & \multirow[b]{2}{*}{67} & \multirow[b]{2}{*}{59} & \multirow[b]{2}{*}{24} \\
\hline NPE (civilian) per capita (1937 FF) & & & & & & \\
\hline Public employment per 1.000 inhab. & 11.9 & 2.0 & 2.9 & 1.7 & 3.9 & 1.3 \\
\hline Annual average public wage (1937 FF) & 15,241 & 11,194 & 12,016 & 15,612 & 5,420 & 6,189 \\
\hline in units of GDP per $15+$ pop. & 1.2 & 8.6 & 4.3 & 14.8 & 4.5 & 7.4 \\
\hline \multicolumn{7}{|l|}{ Year 1955} \\
\hline NPE (civilian) per capita (1937 FF) & 2,773 & 190 & 490 & 34 & 210 & 150 \\
\hline Public employment per 1.000 inhab. & 21.6 & 4.5 & 6.8 & n.a. & 5.0 & 3.1 \\
\hline Annual average public wage (1937 FF) & 27,447 & 20,195 & 23,660 & n.a. & 11,959 & 17,593 \\
\hline in units of GDP per $15+$ pop. & 1.3 & 7.6 & 5.5 & n.a & 5.8 & 10.5 \\
\hline
\end{tabular}

Notes: NA: North Africa; WCA: West and Central Africa. Public employment in the central government only, excluding the military. In 1955 Madagascar, following the 1946 decentralization reform, provinces represented a large share of total public employment; hence, we extrapolated it from personnel expenditure, assuming that provincial employment was paid the same average wage as central government employment.. France 1925: employment from 1922 and wage bill from 1923. NA 1925: Tunisian employment and wages from 1924. 


\section{Appendix I - Income distribution in French colonies and estimates of the fiscal burden on Europeans and autochthons}

We attempt to estimate the distribution of the fiscal burden in the French empire, not only between Europeans and autochthons, but also, within autochthons, between the poor, mostly subsistence farmers, and the non-poor, those who took part in the formal sector and were therefore more likely to contribute to modern taxation like the income tax or taxes on sales revenue. To obtain the fiscal contribution of each group (Europeans, the autochthonous non-poor, and the autochthonous poor), we first estimate their income share in total income. We then make assumptions on the incidence of the different tax instruments on each group. The exercise remains speculative, as available data are patchy and many assumptions are needed. Estimates for 1955 are more reliable than for 1925.

\section{Income shares of Europeans and autochthons in 1955}

We first estimate the share of European settlers in national income. Data availability makes this estimation easier for 1955 than for 1925.

In North Africa, the social tables we use to estimate income shares include Jews in the group of European settlers (in Algeria, Jews were granted French citizenship in 1870). For comparability, we also include the Chinese and Indian minorities in Madagascar in the group of European settlers. In Indochina, the Chinese population, far more numerous than the European population, is treated as autochthonous.

For the year 1955, Samir Amin gives estimates of the income shares of European settlers (and Jews) in Algeria (47\%), Morocco (37\%), and Tunisia (43\%), drawing from household consumption surveys, studies on agricultural incomes and estimates of savings (Amin 1966, pp.114-117). Using these figures and our estimates of GDP per capita and population shares, we estimate the income per capita of Europeans in Algeria, Morocco and Tunisia at respectively 11,850, 10,300 and 12,000 francs (all figures in 1937 PPP terms). This is to be compared with a GDP per capita of 13,900 in Metropolitan France. It seems plausible that average incomes in Metropolitan France and of Europeans/Jews in North African colonies were close, as the occupational structure of Europeans/Jews in North Africa was similar to the French occupational structure (Amin 1966, pp. 156-158, 167-168, 177).

In the cases of Tunisia and Algeria, we can check the consistency of these figures with income tax tabulations collected by Alvaredo, Cogneau and Piketty (2017). In 1955 Tunisia, 
they give the average income of those eligible to pay the income tax, who represented the 39\% richest of the group of Europeans (excluding Jews). To recover the income per capita of the whole group, including those who did not pay the income tax, we assume that the income distribution of Europeans in Tunisia was the same as in Metropolitan France (taken from the WID.world database ${ }^{1}$ ).We find an average income per capita of 10,700 , not far from the above estimate of 12,000 using Amin's share. In 1955 Algeria, income tax tabulations do not distinguish Europeans, or non-Muslims, from Muslims. Yet, we can assume that almost all of those rich enough to pay the income tax were Europeans or Jews - in 1955 Tunisia, nonEuropeans represented just $26 \%$ of those eligible to pay the income tax, and it is not impossible that a majority of them were Jews. Then, assuming again that income distribution among Europeans/Jews was the same as in Metropolitan France, we obtain an income per capita of 12,300 , very close to our 11,850 figure.

For other colonies, we start from Amin's estimates of income by group in 1959 Senegal and 1950 Côte d'Ivoire (Amin 1971, pp. 48, 62, 96-98); the income of Europeans is estimated as the total of wages, benefits of medium and small-size firms and housing rents in the foreign sector ("secteur étranger"). Europeans earned on average 25,250 francs in Senegal (20\% of total income for 1.5\% of population) and 49,800 francs in Côte d'Ivoire (19\% of total income for $0.5 \%$ of population). European settlers in Senegal represented the majority of Europeans in AOF (53\%), and they were on average less skilled than in the rest of the federation. Côte d'Ivoire was also the second wealthiest colony in AOF after Senegal. Europeans living in other colonies of AOF were likely more similar to those in Côte d'Ivoire than to those in Senegal; yet they also likely earned less, so that we estimate their average income per capita by applying the same ratio (41) to average GDP per capita as in Côte d'Ivoire. We obtain, for the whole AOF, an average European income of 30,228 francs and a European income share of $12 \%$ (for less than $0.4 \%$ of population). In other African colonies we assume that the average income per capita of Europeans was the same as in AOF in nominal terms and only adjust for differences in price levels. We estimate European income shares at respectively 4, 14 and 9\% in Togo, AEF and Cameroon, which gives for the whole of West and Central Africa an income share of $12 \%$, and an average European income of 28,349 francs, twice the GDP per capita of Metropolitan France (Table A.1). In Madagascar where Europeans/Asians represented a much larger share of the population (1.5\%, with Asians representing less than a

\footnotetext{
${ }^{1}$ https://wid.world
} 
third), we estimate that they earned $27 \%$ of total income, with an average income of 19,000 francs.

\section{Income shares of Europeans and autochthons in 1925}

In 1925 Indochina, income tax tabulations from Alvaredo, Cogneau and Piketty (2017) cover almost all Europeans and provide us with a direct estimate of their income share: 9\%, for $0.13 \%$ of the population, corresponding to a very high income per capita of 44,500 francs (all figures in 1937 PPP terms). Note that a similar calculation for 1945 indicates a decrease in income per capita to 16,000 francs, as the economy was collapsing during the war, and a lower income share of $7 \%$.

In the other colonies, we lack data on the distribution of income in 1925. To obtain European income shares, we assume that the income per capita of Europeans grew at the same rate as local GDP per capita between 1925 and 1955; in other terms, we assume that the income share of Europeans moved in line with their population share. We tried more sophisticated calculations isolating the public sector, and making use of our public wage and employment data. However, everywhere civil servants never represented more than $30 \%$ of total European employment and most often no more than $15 \%{ }^{2}$; furthermore, the growth in real public wages was not entirely at odds with that of GDP per capita. As we have no additional information on private incomes to bring in, we prefer to stick with the simplest assumption. We obtain income shares of respectively 66, 17 and 49\% for Europeans in 1925 Algeria, Morocco and Tunisia. Income tax tabulations for 1932 Algeria provide us with a check; assuming that all eligible taxpayers were Europeans/Jews (the top 19\% richest) and that the income distribution was the same as in 1925 France, we obtain the same income share (65\%) as with our estimation procedure. In contrast with 1955, European income in Algeria

\footnotetext{
${ }^{2}$ In North Africa, the share of Europeans in public employment is estimated at $60 \%$ in 1925 and in 1955 . This figure is consistent with Amin's for 1955 (pp.153, 161 \& 174: 67\% in Algeria, 60\% in Tunisia \& Morocco), and with a $62 \%$ figure from the 1936 population census of Algeria. Yet only a small minority of Europeans worked in the public sector, the maximum share being 12\% in 1955 Morocco. For 1925 Madagascar, we know the share of Europeans in total public employment: 11.5\% (table A2.1, Appendix II), and even in each administrative subsector. For 1955, we estimate the number of French civil servants by applying the 1925 shares (the 1946 shares are very similar) to the 195 distribution of employment by subsector; we find that Europeans made $12.9 \%$ of total employment (11.7\% in 1946, table A2.1). Yet, as the population share of Europeans nearly doubled, the weight of the public sector in European employment went down from 10 in 1925 to 5\% in 1955. For the colonies of West and Central Africa, we apply the same procedure and estimate that Europeans represented 9\% of public employment in 1925, and 12\% in 1955. The share of the public sector in European employment is then estimated at $28 \%$ in 1925 WCA, and again goes down to $18 \%$ in 1955 with migration inflows to the private sector; our estimate for 1955 Cameroon fits with the share of civil servant households according to a European census in 1938.
} 
lay above French GDP per capita (10,200 vs. 8,800), close to it in Tunisia $(9,700)$ and below in Morocco (6,700). In 1925 Madagascar, we estimate a European income share of $14.1 \%$ for $0.81 \%$ of the population, corresponding to an average income per capita of 13,300 francs (Table A.1). Last, for 1925 West and Central Africa, we estimate an income share of $2.7 \%$ for $0.08 \%$ of the population, and an average income of 17,200 . Hence, according to these very tentative estimates, French settlers in Sub-Saharan Africa were richer than the French average, by 40 to $80 \%$, but it was only in Indochina that settlers were extremely rich, earning five times the French GDP per capita.

Table A1.1 — Income distribution estimates for the years 1925 and 1955

\begin{tabular}{|c|c|c|c|c|}
\hline \multirow[b]{2}{*}{ Year 1925} & NA & Indochina & Madag. & WCA \\
\hline & & & & \\
\hline Europeans: Population share (\%) & 9.19 & 0.13 & 0.81 & 0.08 \\
\hline Income share $(\%)$ & 49.2 & 8.8 & 14.1 & 2.7 \\
\hline Average income per capita (FF 1937 PPP) & 9,638 & 44,528 & 13,324 & 17,222 \\
\hline Non-Europeans Average income (FF 1937 PPP) & 1,009 & 578 & 666 & 518 \\
\hline Year 1955 & & Year 1945 & & \\
\hline Europeans: Population share (\%) & 8.37 & 0.16 & 1.54 & 0.36 \\
\hline Income share (\%) & 41.5 & 7.4 & 26.7 & 11.7 \\
\hline Average income per capita (FF 1937 PPP) & 11,409 & 16,105 & 19,019 & 28,349 \\
\hline Non-Europeans Average income (FF 1937 PPP) & 1,471 & 333 & 817 & 781 \\
\hline
\end{tabular}

Source: Social tables from Samir Amin (1966 and 1971), income tax tabulation data from Alvaredo, Cogneau and Piketty (2017). Notes: Europeans include Jews in NA, and Indians and Chinese in Madagascar.

Income and population shares of the autochthonous poor and non-poor

In a second step, we endeavor to break down the autochthonous population in two social classes: the "non-poor" and the "poor”. The autochthonous non-poor will be assumed to pay what we call modern taxes, whereas the poor, mostly subsistence farmers, will be assumed to pay none. As data are even scarcer for this second step, we restrict ourselves to Algeria, Tunisia, and AOF.

For 1955 North Africa, Samir Amin provides population and income shares for rural and urban Muslims in each colony (Amin 1966, pp. 114-117). ${ }^{3}$ He also provides a three-class population and income breakdown of the rural and urban societies (pp. 130, 136, 141, 155156 and 166). Our "non-poor" group is composed of the two richest classes of the urban

\footnotetext{
${ }^{3}$ We checked that Amin's figures are consistent with data from the population census of Algeria in 1954 and of Tunisia in 1956: Muslims in municipalities with more than 20,000 inhabitants make respectively $16.5 \%$ and $15.2 \%$ of total population. In Tunisia, Muslims in the 10,000-20,000 range make an additional 6.4\%.
} 
Muslim population and the richest class of the rural Muslim population (wealthy farmers). Our "poor" group is composed of the two poorest classes of the Muslim rural population and the poorest class of the Muslim urban population (servants and unskilled laborers). We obtain that the autochthonous non-poor make $16 \%$ of the population and earn $24 \%$ of income in Algeria. They make 20\% of the population and earn 30\% of income in Tunisia. Their average income is about a third of the average European income and four times as high as the average income of the poor (Table A.2).

Amin also provides estimates of the share of urban Africans in population and income for 1959 Senegal and 1950 Côte d'Ivoire. In absence of a more detailed breakdown, we use the urban share to estimate the share of the non-poor. We treat Côte d'Ivoire as representative of other AOF colonies and take a population weighted average of the shares. From this we estimate that the African non-poor in AOF made around $11 \%$ of total population and $36 \%$ of total income in 1955. It means they earned about the same income as the Muslim non-poor in North Africa, ten times less than the tiny minority of European settlers, and five times more than the African poor (Table A.2).

Building estimates for 1925 is quite a heroic task. In North Africa, to estimate the population share of the non-poor, we estimate the urbanization rate of the Muslim population and assume the same share of rural non-poor and of urban poor as in $1955 .^{4}$ In AOF, we use the urbanization rate computed from Africapolis to estimate the share of the African non-poor (see also data Appendix on urban population figures). ${ }^{5}$

Finally, to break down the estimated income share of the autochthonous population into the shares of the non-poor and the poor, we make the simple assumption that the income per capita of the non-poor grew at the same rate as the income per capita of all autochthons; in other terms, we assume that the income share of the non-poor moved in line with their population share among autochthons. To check that we obtain plausible estimates of average income, we compare the figures of Table A1.2 with the price of a yearly ration of 1,600 kcal of wheat (584 francs in Algeria, 575 in Tunisia, 474 in AOF). In Algeria and Tunisia the average income of the poor lies $20 \%$ above the price of a yearly ration. In AOF, it lies $7 \%$ below. According to the estimates presented in Table A1.2, Income inequality increased

\footnotetext{
${ }^{4}$ The 1926 Algerian population census indicates that only $11 \%$ of the Muslim population live in the 46 biggest cities. The 1921 Tunisian population census reports the number of Muslims for the five biggest cities only. We assume the ratio of Muslims to non-Muslims in the 24 smallest cities to be the same as in the four biggest cities outside of Tunis. We obtain that $10 \%$ of the Muslim population lives in the 29 largest cities.

${ }^{5}$ http://africapolis.org. We thank Eric Denis for sharing unpublished data on AOF before 1950. We interpolate Africapolis estimates between 1920 and 1930. We obtain an urbanization rate of 1.7\%, vs. 1.3\% if we take Eggiman's figures (Eggiman 1999).
} 
sharply in AOF between 1925 and 1955, in parallel with the urbanization boom. In the two North-African colonies, the evolution is more ambiguous: while the income gap between Europeans and autochthons narrowed, it seems than inequality among autochthons increased.

Table A1.2 — Income distribution estimates for the years 1925 and 1955

\begin{tabular}{lccc} 
& Algeria & Tunisia & AOF \\
\cline { 5 - 5 } Year 1925 & & & \\
\cline { 1 - 1 } Europeans: Population share (\%) & 14.41 & 9.49 & 0.09 \\
Income share (\%) & 65.8 & 49.4 & 3.2 \\
Average income per capita (FF 1937 PPP) & 10,214 & 9,655 & 17,975 \\
Autochthonous non-poor: Pop. (\%) & 10.9 & 17.4 & 1.7 \\
Income share (\%) & 10.8 & 23.3 & 6.0 \\
Average income per capita (FF 1937 PPP) & 2,208 & 2,480 & 1,951 \\
Autochthonous poor: Population (\%) & 74.7 & 73.1 & 98.3 \\
Income share (\%) & 23.4 & 27.3 & 90.8 \\
Average income per capita (FF 1937 PPP) & 700 & 693 & 497 \\
Year 1955 & & & \\
\cline { 1 - 1 } Europeans: Population share (\%) & 10.24 & 8.23 & 0.36 \\
Income share (\%) & 46.8 & 42.9 & 12.1 \\
Average income per capita (FF 1937 PPP) & 11,854 & 12,005 & 30,228 \\
Autochthonous non-poor: Pop. (\%) & 16.3 & 20.2 & 10.9 \\
Income share (\%) & 24.0 & 30.1 & 35.9 \\
Average income per capita (FF 1937 PPP) & 3,806 & 3,435 & 2,985 \\
Autochthonous poor: Population (\%) & 73.4 & 71.6 & 88.8 \\
Income share (\%) & 29.2 & 27.1 & 52.0 \\
Average income per capita (FF 1937 PPP) & 1,033 & 873 & 530
\end{tabular}

Source: Social tables from Samir Amin (1966,1971), income tax tabulation data from Alvaredo, Cogneau and Piketty (2017), and urbanization data from various sources (see text). Notes: Europeans include Jews in North Africa.

\section{Tax rates}

In the settlement colonies of Algeria and Tunisia, the European and Jewish population paid a disproportionate share of the direct taxes; for example in 1955 Tunisia, Europeans represented $74 \%$ of income tax payers (78\% of taxable income), and the remaining $26 \%$ were perhaps overwhelmingly Jews (Alvaredo, Cogneau and Piketty 2017). ${ }^{6}$ They also paid quite a lot of the taxes on imported consumer goods, alcoholic drinks in particular. Generally speaking, most of the modernized taxation apparatus applied to a formal sector built around the settlers' enclave, so that Europeans also paid a large share of turnover taxes and of

\footnotetext{
${ }^{6}$ See also Nicolaï (1962, pp. 447-450).
} 
registration fees. ${ }^{7}$ Yet their income share was also very high, always above $40 \%$, and even as high as 66\% in 1925 Algeria, according to our estimates (Tables A1.1 and A1.2 above).

In the rest of the colonial empire, where settlers were few, autochthons had to pay the bulk of the tax bill. Though European settlers were richer than their counterparts in North Africa, and much richer than autochthons (Table A1.1), they were not enough to generate large revenue. ${ }^{8}$ Before World War II, direct taxation of income was limited. ${ }^{9}$ In AOF, the Metropolitan general income tax had been gradually introduced after 1930, and schedular taxes on wages, profits and investment income appeared in 1942 (Doublet 1952, pp.109-112). The "prestations" system of forced labor taxation was abolished in 1946. Head tax rates were already different between districts, depending on urbanization and affluence; at the beginning of the 1950s they started to be fixed according to individual occupation or income, hence becoming mildly progressive (Doublet 1952). ${ }^{10}$ Yet, the rates were also significantly raised: between 1925 and 1955 the revenue per capita from capitation more than doubled in AOF (from 9 to 21 francs in 1937 PPP).

In North Africa like in Sub-Saharan Africa, between 1925 and 1955 the weight of modern taxes in total revenue increased, and the weight of the most archaic tax, capitation, decreased (see Table 3 in the main text). Modern taxes being the most progressive and capitation the most regressive of all taxes, one could expect that tax systems turned more progressive overall. Yet, the apparent modernization of the tax structure could very well only reflect colonial inequality and/or the structural change of colonial societies. Where Europeans obtained a higher share of income, the share of revenue from modern taxes or from import duties was mechanically higher. Likewise, where or when more autochthons migrated to cities and obtained wage jobs, the tax structure looked more modern due to the same composition

\footnotetext{
${ }^{7}$ For 1956 Tunisia, Nicolaï estimates that indirect taxes paid by Europeans could be more than $50 \%$ of total indirect tax revenue (Nicolaï 1962, p. 453).

${ }^{8}$ Even under upper bound assumptions for their contribution (see below), Europeans contribute to only a tiny share of total tax revenue in AOF, both in 1925 (11\%) and in 1955 (18\%).

${ }^{9}$ In Indochina 1920-1937, Europeans only paid a minimal lump-sum tax on income based on twelve brackets. The land tax weighed disproportionately on autochthons, while trading licenses were shared more or less equally: see Gouv. Gal de l'Indochine, 1931. Annuaire Statistique de l'Indochine, deuxième volume, 19231929, Hanoi : Imprimerie d’Extrême Orient, pp. 311 (Annam) \& 327 (Tonkin). In 1938, a general income tax was introduced, that also extended to rich Chinese and Indochinese.

${ }^{10}$ For instance in 1950 Côte d'Ivoire, four categories of occupations were distinguished, going from highrank civil servants, large landowners and big traders to unskilled wage earners or petty traders, with head tax rates ranging from 1,000 francs to 4,500 francs. A fifth class gathered the rest of the population above 15 years of age, including all the smallholders and all the women without occupation. The latter class represented more than $97 \%$ of the total population of tax payers and paid a capitation ranging from 95 to 280 francs, depending on the district of residence (Doublet 1952, pp.71-80). Dahomey, Guinea and Niger had similar schedules, and Togo distinguished taxpayers according to three brackets of income. Despite the discrepancy in rates, the progressivity was attenuated by the fact that even rich men would pay the base rate for their wife or their children above 15 year-old (and actually 0 for schooled teenagers).
} 
effect. This is why we need to combine our estimates of population and income shares of the three social groups with the incidence of taxes on each of them, to disentangle actual increases in progressivity from composition effects stemming from structural change.

To estimate the fiscal burden weighing on each of the three groups, we lack the statistical basis (social accounting matrices) and a well-founded general equilibrium model to perform a proper tax incidence analysis. We instead make a couple of simple extreme assumptions to obtain lower and upper bound estimates of tax progressivity.

To obtain lower bound estimates, we make three assumptions regarding the head tax (capitation) and forced labor, the taxes that we categorized as "modern", and the remaining sources of revenue (monopolies, trade taxes, “intermediate” taxes, and other).

(1) Head tax payments are allocated in proportion of the population older than 15. Only the autochthonous poor contribute to forced labor, and we adopt the monetary equivalents proposed by van Waijenburg (2018) for AOF in 1925 (forced labor was abolished in 1946).

(2) The poor pay none of the modern taxes. Europeans and the autochthonous non-poor pay the same percentage of their income in modern taxes.

(3) For all other sources of revenue (monopolies, intermediate internal taxes and trade taxes), the three groups contribute in the same proportion of their income.

All these assumptions understate progressivity. The first one neglects the transition to a less regressive head tax in AOF after World War II. Regarding the second, Europeans must have faced higher rates, given the higher level and the higher formality/visibility of their earnings. ${ }^{11}$ As for the third assumption, the propensity to consume imports, goods produced by the formal sector, or monopoly goods (alcohol, sugar, tobacco) likely increased with income. We thus consider that this set of three extreme assumptions provides us with a lower bound of tax progressivity in each year.

Under these lower bound assumptions (1)-(3), Table A1.3 gives the tax rates on the income of each group in 1925 and 1955, as well as two progressivity indicators: the ratio of the after/before tax ratios of autochthons and Europeans, and the ratio of the after/before tax ratios of the autochthonous poor and non-poor - indicators larger than 1 are the sign of a progressive tax system. The tax system of 1925 Algeria appears mildly progressive, thanks to

${ }^{11}$ In 1945 Cameroon, some 1,300 Europeans paid the general income tax and schedular taxes on wages and profits, while 10,000 autochthons earning more than 6,000 francs (i.e. around four times the GDP per capita) paid a tax on income with a flat rate of $4 \%$; $1,400,000$ other poor autochthons were subject to standard capitation. Revenues collected amounted respectively to 37, 2 and 59 million. Our calculations suggest that Europeans paid $6.7 \%$ of their income on these taxes, against $1.2 \%$ for autochthons. Min. de la France d'OutreMer, 1947. Annuaire Statistique du Cameroun, vol. 1 1938-1945, Paris : Imprimerie Nationale, pp. 128-129. 
the absence of capitation, and as the modern taxes exempting the poor already represented $20 \%$ of revenue. ${ }^{12}$ The tax system of 1925 Tunisia is just neutral: capitation still represents $4 \%$ of total revenue and modern taxes are not as developed (5\% only). Last, the lower bound of progressivity in 1925 AOF is below 1, indicating a regressive tax system, given the weight of capitation and forced labor ( $41 \%$ of total revenue) and the absence of progressive modern taxes.

Table A1.3 — Lower bound estimates of progressivity

\begin{tabular}{lccc} 
& Algeria & Tunisia & AOF \\
\cline { 3 - 4 } Year 1925 & & & \\
\cline { 1 - 3 } Estimated tax rates on income (\%): & & & \\
$\quad$ Europeans & 6.6 & 6.9 & 4.7 \\
$\quad$ autochthons & 5.5 & 7.1 & 8.0 \\
$\quad$ autochthonous non-poor & 6.6 & 7.1 & 5.2 \\
$\quad$ autochthonous poor & 5.0 & 7.2 & 8.2 \\
Progressivity indicators (ratios): & & & \\
$\quad$ autochthons vs Europeans & 1.01 & 1.00 & 0.97 \\
$\quad$ poor vs non-poor & 1.02 & 1.00 & 0.97 \\
Year 1955 & & & \\
Estimated tax rates on income (\%): & & & 13.9 \\
$\quad$ Europeans & 20.1 & 21.0 & 14.7 \\
$\quad$ autochthons & 14.6 & 17.2 & 14.6 \\
$\quad$ autochthonous non-poor & 20.1 & 21.0 & \\
$\quad$ autochthonous poor & 10.1 & 12.8 & 0.99 \\
Progressivity indicators (ratios): & & & 1.00 \\
$\quad$ autochthons vs Europeans & 1.07 & 1.05 & \\
$\quad$ poor vs non-poor & 1.13 & 1.10 & \\
\hline
\end{tabular}

Sources: See text.

Notes: Europeans include Jews in NA. The first progressivity indicator is $\left(1-\mathrm{t}_{\mathrm{a}}\right) /\left(1-\mathrm{t}_{\mathrm{e}}\right)$, where $\mathrm{t}_{\mathrm{a}}$ is the average tax rate on autochthons (second line of each panel), and $t_{e}$ the tax rate on Europeans (first line). The second progressivity indicator is $\left(1-t_{p}\right) /\left(1-t_{n p}\right)$, where $t_{p}$ is the tax rate on the autochthonous poor (fourth line) and $t_{n p}$ the tax rate on the autochthonous non-poor (third line).

Under the same lower bound assumptions, the year 1955 looks more progressive in the three colonies, yet it is in AOF that the change appears the least pronounced. In Algeria the weight of modern taxes reached $41 \%$ of total revenue in 1955. In Tunisia, capitation had disappeared and modern taxes weighed 32\%. In these two countries, according to our estimates the income share of those paying modern taxes (Europeans and the autochthonous non-poor), if anything, decreased slightly (Table A1.2), so that the apparent modernization of the tax system reflected a true increase in progressivity. Indeed, under our assumption, the

${ }^{12}$ For Algeria, Ageron (1990, p. 66) estimates that Europeans paid 53\% of the total tax bill before World War I and 73\% after the suppression of "Arab taxes" in 1919 and the introduction of the income tax. Although he does not explain his method, his figure is close the one corresponding too our lower bound for 1925 (70\%). 
modern tax rates on the income of the two non-poor groups increase from 1.6 to $10.0 \%$ in Algeria, and from 0.5 to $8.3 \%$ in Tunisia. In AOF, thanks in particular to the abolition of forced labor, the share of archaic taxes (capitation and corvée labor) drops from 41 to 16\%; in parallel, the share of modern taxes goes from 0 to $10 \%$. Yet, our estimate of the income share of the non-poor jumps from 9 to $48 \%$, and this boom of the tax base probably explains most of the modernization of the tax structure. ${ }^{13}$ According to our estimates, modern tax rates on the non-poor (Europeans and autochthons) rose from 0.1 to $3.0 \%$ only, while the archaic tax rate on the poor also increased from 3.5 to $4 \%$; recall however that under assumption (1) the reforms of capitation, making it less regressive, are not taken into account here.

In Algeria and Tunisia, the tax system of 1955 is unambiguously progressive between our three groups, primarily along the poor/non-poor line among autochthons (the progressivity indicator reaching 1.13 in Algeria, and 1.10 in Tunisia), and secondarily along the racial line (1.07 and 1.05 in Tunisia). In AOF, under lower bounds assumptions it reaches neutrality; in contrast with 1925, we can at least exclude that is was regressive.

Can we robustly conclude that progressivity unambiguously increased between 1925 and 1955? The main concern is our assumption (3) that the three groups contributed in the same proportion of their income to all sources of revenue other than the head tax and modern taxes. In fact, this could have changed between 1925 and 1955 as the autochthons, especially the non-poor, became more involved in the formal economy, as tax enforcement improved, and as consumption patterns changed towards more imported goods or monopoly goods. To have a significant impact on our estimates of progressivity dynamics, these evolutions should affect taxes other than modern taxes, as modern taxes were not very developed in 1925 (see above).

We alternatively compute a much more progressive estimate of the distribution of taxes by replacing assumptions (1) to (3) by the following ones:

(1') Europeans' average head tax rate (per capita) is twice the non-poor's, and 10 times the poor's (only for 1955);

(2') Europeans face a modern tax rate (on income) that is twice the non-poor's;

(3') Half of the revenue from other taxes is only collected on the non-poor (Europeans and autochthons), like modern taxes, with the same tax rate (on income) for the two groups.

We believe this alternative set of assumptions provides us with an upper bound of tax progressivity. Of course, a more extreme upper bound would have all taxes except capitation

\footnotetext{
${ }^{13}$ The income share of Europeans increases from 3 to 12\%, and the share of non-poor autochthons from 6 to $36 \%$.
} 
paid by the non-poor (or even by the Europeans only). Yet such an extreme assumption generates tax rates on the non-poor groups as high as 50\% in $1925 \mathrm{AOF}$, which seems quite unrealistic.

Table A1.4 reports the results of the numerical simulations under assumptions (1')-(3’).

Table A1.4 — Upper bound estimates of progressivity

\begin{tabular}{|c|c|c|c|}
\hline \multirow[b]{2}{*}{ Year 1925} & Algeria & Tunisia & $\mathrm{AOF}$ \\
\hline & & & \\
\hline \multicolumn{4}{|c|}{ Estimated tax rates on income (\%): } \\
\hline Europeans & 7.5 & 8.2 & 27.7 \\
\hline autochthons & 3.8 & 5.9 & 7.2 \\
\hline autochthonous non-poor & 6.6 & 8.1 & 28.0 \\
\hline autochthonous poor & 2.5 & 4.0 & 5.9 \\
\hline \multicolumn{4}{|l|}{ Progressivity indicators (ratios): } \\
\hline autochthons vs Europeans & 1.04 & 1.04 & 1.28 \\
\hline poor vs non-poor & 1.04 & 1.03 & 1.31 \\
\hline \multicolumn{4}{|l|}{ Year 1955} \\
\hline \multicolumn{4}{|c|}{ Estimated tax rates on income (\%): } \\
\hline Europeans & 24.3 & 25.5 & 22.2 \\
\hline autochthons & 11.0 & 13.8 & 13.6 \\
\hline autochthonous non-poor & 18.3 & 20.3 & 20.3 \\
\hline autochthonous poor & 5.1 & 6.5 & 8.9 \\
\hline \multicolumn{4}{|l|}{ Progressivity indicators (ratios): } \\
\hline autochthons vs Europeans & 1.18 & 1.16 & 1.11 \\
\hline poor vs non-poor & 1.16 & 1.17 & 1.14 \\
\hline
\end{tabular}

Sources: See text.

Notes: See Table A1.3.

To obtain a lower bound for the evolution of progressivity between 1925 and 1955, we can compare the upper bound of progressivity for 1925 from Table A1.4 top panel with the lower bound for 1955 from Table A1.3 bottom panel. In Algeria and Tunisia, the progressivity indicator still increases, from 1.04 to 1.05-1.07 along racial lines and from 1.031.04 to $1.10-1.13$ along the poor/non-poor line among autochthons. Along the racial line, the conclusion of an increase in progressivity even survives assuming a zero tax rate on the poor in 1925, i.e. a very extreme version of assumption (3’).

In AOF, the same comparison indicates a large decrease in progressivity, while the reverse one (lower bound of 1925 to upper bound of 1955) points to a large increase. It is therefore impossible to draw any robust conclusion. Similarly, when we try to compare AOF with the two North African colonies, the "confidence interval" for AOF encompasses the one for Algeria or Tunisia in 1925, and they overlap over a large range in 1955. Though the importance of the head tax and the underdevelopment of modern taxes make it likely that the 
tax system in AOF was more regressive than in North Africa, this conclusion hinges on the fact that other taxes were not more progressive in AOF, which is not granted. ${ }^{14}$

A second uncertainty and concern is that the income share of the autochthonous nonpoor in 1925 was extrapolated under a strong assumption. We also explored the sensitivity of our comparisons to this parameter. In Algeria and Tunisia, halving this income share, that is assuming that the tax base of modern taxes was narrower, barely increases progressivity in 1925 because modern taxation was still limited. Our conclusion of a progressivity increase again survives. ${ }^{15}$ In AOF, halving or doubling the income share does not reduce ambiguity.

We conclude that despite the uncertainties attached to the income distribution and to the sharing of the tax burden in each year and especially in 1925, it is likely that tax progressivity increased in Algeria and Tunisia, even if the improvement was perhaps modest. Further, our lower bound estimates make implausible that the colonial tax system was purely regressive along racial lines, even in 1925, yet its progressivity could also have been very limited. In the case of AOF, the importance of capitation and forced labor means it is possible the tax system was regressive in 1925, but the confidence intervals are too large to draw any robust conclusion on progressivity comparisons, across time or across space.

\section{References}

Alvaredo, Facundo, Denis Cogneau and Thomas Piketty. "Income Inequality under Colonial Rule. Evidence from French Algeria, Cameroon, Indochina and Tunisia, 1920-1960”, PSE working paper, 2017.

Ageron, Charles-Robert. Histoire de l'Algérie Contemporaine, Paris: PUF, 1990.

Amin, Samir. L'économie du Maghreb. La colonisation et la décolonisation. Paris : Editions de Minuit, 1966.

Amin, Samir. L'Afrique de l'Ouest bloquée. L'économie politique de la colonisation 18801970, Paris : Editions de Minuit, 1971.

Doublet, Pierre. Traité de législation fiscale dans les territoires d'outre-mer, II : Régimes fiscaux de l'Afrique Occidentale Française et du Togo, Paris : Sirey, 1952.

Nicolaï, André. “Tunisie : fiscalité et développement”, Tiers-Monde 3 n¹1 (1962) : 429-478.

\footnotetext{
${ }^{14}$ Regarding assumption (2') compared to (2), it might seem quite unlikely that modern taxes turned less progressive between 1925 and 1955. We checked that keeping the same assumption (either 2 or 2') in both years did not modify our conclusions. This mechanically reinforces our conclusion on the improvement of progressivity in North Africa, and leaves the ambiguity in AOF unchanged.

${ }^{15}$ The upper bounds of progressivity indicators for 1925 are then 1.05/1.05 instead of 1.04/1.04 in Algeria, and 1.05/1.06 in Tunisia.
} 


\section{Appendix II — Public wages in Indochina and Madagascar 1925-1946}

Dualism decomposed: public wages of French and autochthons in civil service

A systematic breakdown of public employment and wages by citizenship is possible for Madagascar and Indochina in the 1920s and 1940s. As shown in Table A2.1 (first and second rows), while in both colonies French civil servants represented $12 \%$ of total employment in 1925, they made up 52 to $56 \%$ of the wage bill. Similar data for 1943-1946 show that the autochthons' share in public employment remained stable over two decades. ${ }^{1}$

Table A2.1 - French and autochthons in civil service 1925 \& 1945, Indochina and Madagascar

$$
\text { Indochina Madagascar }
$$

\begin{tabular}{|c|c|c|c|c|}
\hline \multirow{3}{*}{ Year 1925} & \multicolumn{2}{|c|}{ Indochina } & \multicolumn{2}{|c|}{ Madagascar } \\
\hline & French & autochthons & French & autochthons \\
\hline & & & & \\
\hline Share in total employment (\%) & 12 & 88 & 12 & 88 \\
\hline Share in wage bill (\%) & 52 & 48 & 56 & 44 \\
\hline Average annual public wage (1937 FF) & 62,509 & 7,879 & 34,653 & 3,609 \\
\hline in units of GDP per 15+ pop. & 59.3 & 7.5 & 28.7 & 3.0 \\
\hline in units of GDP per $15+$ of each group ${ }^{a}$ & 0.9 & 8.2 & 1.0 & 3.5 \\
\hline Years 1943-1946 & & & & \\
\hline Share in total employment (\%) & 10 & 90 & 12 & 88 \\
\hline Share in wage bill (\%) & 42 & 58 & 49 & 51 \\
\hline Average annual public wage (1937 FF) & 27,697 & 4,189 & 25,326 & 3,512 \\
\hline in units of GDP per 15+ pop. & 47.9 & 7.2 & 21.5 & 3.0 \\
\hline in units of GDP per $15+$ of each group ${ }^{a}$ & 1.0 & 7.8 & 1.2 & 3.8 \\
\hline
\end{tabular}

Notes. In Madagascar, 1925 is the average of 1921 and 1929 (the distribution of employment and wages by citizenship is not given in 1925); data for the 1940s is 1946. Figures for Indochina in the 1940s do not comprise the federal government, only the local budgets of Cochinchina (1944), Annam (1945), Tonkin (1945), Cambodge (1945) and Laos (1943). In 1925, wages are higher by $80 \%$ for autochthons at the federal level, yet employment is only $9 \%$ of total, so that not including the federal budget is innocuous. a: using estimates of average income of French and autochthons, see Online Appendix Table A1.1 (the estimate for Indochina uses income tax data from 1942).

Not only were French wages much higher on average than autochthonous wages (7 times higher in Indochina and 10 times in Madagascar), they were, in 1925, higher than the average public wage in Metropolitan France. In Madagascar, the French public wage of 35,000 francs was 2.2 times higher than the average public wage in Metropolitan France $(15,000)$. In Indochina, it was more than 4 times as high $(62,500)$.

\footnotetext{
${ }^{1}$ Data for 1912-13 Indochina suggest that the share of French was just a bit higher, at $13 \%$. Whereas it had expanded by more than 40\% from 1913 to 1925, public employment did not increase between 1925 and 1937, and fell by around 15\% during WWII.
} 
The second section of this appendix gives a more detailed account of the rise in public wages in Indochina after World War I. In a nutshell, the colonial government of Indochina set up a specific schedule of bonuses for French public wages to retain their purchasing power and stay in line with private earnings. A version of the schedule of bonuses used to compensate French civil servants in Indochina was also used to increase the wage of autochthonous civil servants. Increasing inequalities in pay within the colonial civil service even further was politically infeasible - colonial administrators mention the "necessary parallelism” between French and Indochinese civil servants. It is therefore likely that the very high wages paid to French civil servants were pulling the autochthonous wage schedule upwards. Though bonuses were originally reserved for French citizens, in skilled occupations like teachers, some allowances could be extended to autochthons. ${ }^{2}$ Measures of wage dualism from Table 5, however, are very much decreased when we consider only the wages of autochthons. In 1925 Madagascar, wage dualism goes from 4.5 to 3.0 (3.5 when we exclude Europeans from GDP per working age population). In 1925 Indochina, it goes from 14.8 to 7.2 (7.8).

The rise and fall of Indochinese public wages from World War I to World War II

As already mentioned, average public wages were particularly high in 1925 Indochina. The average French public wage was $80 \%$ higher than the average French public wage in Madagascar, and more than twice the average French public wage in 1945 Indochina. Autochthonous public wages were very high as well, again about twice higher than in Madagascar or 1945 Indochina. We lay down here the particular sequence of policies that led to these extremely high real wages.

At the top of the hierarchy, the general governor was paid 1937 PPP FF 406,000 in 1925 Indochina vs. 280,000 in Madagascar — a 45\% difference. The base nominal wage in current francs was in fact different by $25 \%$ only $(50,000$ vs. 40,000$)$. Both governors received the same large bonuses, about 2.8 times the base wage (at the 1925 exchange rate of the Indochinese currency, the piaster), comprising not only the “colonial supplement” but also travel and entertainment expenses. The rest of the difference then stemmed from the price level, 18\% lower in Indochina according to our estimates. However, in 1925 Indochina the

\footnotetext{
${ }^{2}$ For instance, West African teachers exerting outside of their colony of origin, i.e. in the intermediate "federal” schedule, benefited from a remoteness allowance ("indemnité de dépaysement") equal to 4/10 of base wage. Further, from 1925 to 1935 all African teachers in Togo were granted a special bonus ("indemnité spéciale du Togo"), first equal to 6/10, then 7/10 in 1927, and gradually diminished to 3/10 in 1933 before being cancelled due to financial restrictions. Gbikpi-Benissan (2011, vol. 2, p. 205).
} 
same level of bonuses applied to all French civil servants, more than tripling the base wage in francs. In Madagascar, like in other colonies of Sub-Saharan Africa, bonuses and allowances only reached $70 \%$ of base wages.

The story of these very high Indochinese wages is the following. At the start of World War I, France had suspended the convertibility of the French franc into gold. France financed the war by monetary expansion, resulting in high inflation. In Indochina, the piaster remained silver based and inflation was low throughout the war and in the 1920s. As a result, the piaster appreciated from 2.5 francs for one piaster in 1913 to 17 francs for one piaster in 1926. The exchange rate stabilized around 12 under the Poincaré government, before being pegged at 10 after 1930 (Brocheux \& Hémery, pp. 134-135; Giacometti, 1998).

From 1913 to 1917 in Metropolitan France, nominal wages of civil servants had stayed fixed and had lost a lot of purchasing power. Nominal wages were gradually increased from 1918 to the end of the 1930s, starting with the lowest wages of postmen, teachers, etc. By 1925 , the top wages of university professors or administration executives were still lower by 40\% than their 1913 level (Piketty 2018 pp. 182-191 \& pp. 833-834). For expatriate French civil servants, the wage schedule of Metropolitan France applied directly to all colonies, so that in Indochina base wages in francs were converted in piasters.

In Indochina, the colonial government decided to set up a specific schedule of colonial supplements in piasters to compensate for inflation in Metropolitan France (Dareste et al. $\mathrm{N}^{\circ}$ 4, Oct.-Dec. pp. 1080-1083). The schedule was progressive, in that wages at the bottom of the scale received proportionally higher supplements. It was revised each year all along the 1920s. The Indochinese supplement fixed in piaster ended up representing the bulk of the pay: in 1925, it ranged between 2 to 4 times the base wages, when going down the scale from the top (governor) to the bottom. In contrast with Metropolitan France, the average wage of French civil servants in Indochina even increased between 1913 and 1925, from 1937 PPP FF $52,649$ to 62,509 (i.e. by $19 \%)^{3}$

According to a September 1920 decree, the "colonial supplement" had to be six tenth of the base wage in francs in Madagascar, and seven tenth in Indochina (Dareste et al. $\mathrm{N}^{\circ} 1$, Jan.Mar. pp. 89-98). Our data indicate that in Madagascar the applied supplement was actually seven tenth. ${ }^{4}$ In Indochina, the specific supplement schedule did not fit the seven tenth rule

\footnotetext{
${ }^{3}$ The general governor and the governors of four territories (not Cochinchina) make one exception, but it is that their base nominal wages in francs were lowered between 1913 and 1925.

${ }^{4}$ The colonial supplement was supposed to be seven tenth in AOF and nine tenth in AEF. Our data rather suggest it was seven tenth in all Sub-Saharan Africa colonies until the end of WW2. Before WW1, it seems to have doubled the base wage in SSA and Indochina.
} 
and was more advantageous, especially for low wages. For example, a French civil servant paid at the Madagascar 1925 average wage of around 9,325 francs, corresponding to a middle rank executive or to a second class teacher, received a 6,527 francs supplement in Madagascar, but 3,990 piasters in Indochina, worth 31,290 francs at the 1925 exchange rate. The bulk of the gap in French public wages between Madagascar and Indochina in 1925 can be attributed to the specific schedule of bonuses in Indochina.

Why did the government of Indochina adopt such a generous bonus schedule? Strikingly enough, our estimates of the average income of Europeans (Table A1.1 in Appendix I), when expressed in per worker terms, stand at par with average wages in the civil service in both colonies (Table A2.1, last row of each panel). ${ }^{5}$ Then, everything is as if the large bonuses paid to civil servants in Indochina were meant to offset a high reservation wage, as Europeans in the private sector were much richer and in lower numbers than in Madagascar, where many relatively poor French men from neighboring Réunion island had immigrated. Hence, the rationale for the Indochinese exception must have been the wish to attract skilled civil servants in the most profitable and strategic, yet remote, colony.

It is only at the end of 1930s that the difference between the arbitrary piaster supplement and the seven tenth bonus turned small, at all base wages. Nominal wages in francs had recovered, so that the special supplement schedule had gradually lost its motivation. Furthermore, the bankruptcies of the Great Depression had also diminished private benefits, hence the civil servants’ reservation wage (Brocheux and Hémery 1994, pp. 260-269). World War II finished pulling down public wages in Indochina, back to the same levels as in Madagascar. According to Bassino's estimates, the once buoyant Indochinese economy collapsed under the Japanese occupation - GDP per capita was halved between 1940 and 1945. Between 1937 and 1945, inflation was extremely high in both colonies — prices were multiplied by 5.8 in Indochina and 6.7 in Madagascar, but nominal wages did not follow in Indochina. In both colonies, between 1925 and 1943/46, French public wages kept up with Europeans' average earnings, which fell by $60 \%$ in Indochina, but only by $25 \%$ in Madagascar (in Madagascar the average earnings of Europeans fell mostly because of the arrival of new, less affluent settlers in the 1930s).

The setting of French wages also influenced the wages of autochthons. In 1925, the average French civil servant was paid 8 to 10 times what the average autochthon received in both colonies (Table A2.1, third row). This means that autochthonous civil servants were paid

\footnotetext{
${ }^{5}$ At least for Indochina, these are rather precisely measured thanks to income tax data collected by Alvaredo, Cogneau \& Piketty (2017).
} 
twice more in Indochina. It is quite surprising, as Indochinese civil servants were not paid the colonial supplement, reserved for French citizens. Sources indicate that some "parallelism" was sought between the French and local wage schedules. During the period of the depreciation of the franc (1918-1930), a generous and progressive exchange rate was applied to translate wages from francs into piasters. In 1926 for instance, when the actual exchange rate was around 10 francs per piaster, an exchange rate 3 to 3.5 (depending on base wage level) was applied, meaning a bonus of $10 / 3-1=2.33$ in terms of the base wage in francs. ${ }^{6}$ The wages of subaltern personnel, which had no correspondence in francs, were presumably also pulled upward. Overall, the real wages of autochthonous civil servants also went up between 1913 and 1925, from 1937 PPP FF 4,219 to 7,086 - a 87\% increase. $^{7}$

This “parallelism” between Europeans' and autochthons' wage schedules then explains why our measure of wage dualism is so high in 1925 Indochina compared to Madagascar. In Indochina, the average autochthon in civil service earned 7.5 times the GDP per worker, while the same ratio was only 3.0 in Madagascar (Table A2.1, fourth row).

In 1946, the autochthons' average wage had improved significantly in Madagascar. It was now 7.2 times lower than the French average wage, versus 9.6 times in 1925. In Indochina, the autochthons once generous schedule was, like the French schedule, shifted down drastically. Average public autochthonous wages were 6.6 times lower than French wages in 1943/46, versus 7.9 times in 1925.

\footnotetext{
${ }^{6}$ See for instance, where the term “parallelism” is used: Gouvernement Général de l’Indochine, 1931. Recueil général de la législation et de la réglementation de l'Indochine, Supplément de 1926-1927, Deuxième partie (Arrêtés, décisions et circulaires du gouverneur général et des chefs d'administration locale) et Troisième partie (Ordonnances des souverains de l'Annam, du Cambodge et de Luang-Prabang), pp. 154-156. [National Library of Vietnam]. "Un taux d'abondement dégressif a dû être adopté pour conserver le parallélisme nécessaire entre les deux traitements.”

${ }^{7}$ Employment increased more in administrative sectors paying initially higher wages, like education and health, yet the composition effect was limited.
} 


\section{References}

Alvaredo, Facundo, Denis Cogneau and Thomas Piketty. "Income Inequality under Colonial Rule. Evidence from French Algeria, Cameroon, Indochina and Tunisia, 1920-1960”, PSE working paper, 2017.

Brocheux, Pierre and Daniel Hémery. Indochine, la colonisation ambigüe 1868-1954, Paris: La Découverte, 1994 [2nd ed. 2001].

Dareste P., G. Appert, L. Rotureau-Delaunay et A. Marcille (dir.), Recueil de législation, de doctrine et de jurisprudence coloniale, 24ème année, Paris: G. Godde.

Giacometti, Jean-Dominique. «La bataille de la piastre 1918-1928. Réalités économiques et perceptions politiques dans l'Empire colonial Français. » Humboldt-Universität zu Berlin, Philosophische Fakultät III, Institut für Asien und Afrikawissenschaften, working paper No. 9, Berlin, 1998.

Gbikpi-Benissan, François. Le système scolaire au Togo sous mandat français, 2 volumes, Paris: L’Harmattan, 2011. 


\section{Appendix III}

\section{General historical references on the "Second" French Colonial Empire}

\section{General History}

\section{French Empire}

Ageron, Charles-Robert. La décolonisation française. Paris: Armand Colin, 1991.

Binoche-Guedra, Jacques. "Le rôle de l'Algérie et des colonies au Parlement sous la Troisième République (1871-1940)”. Revue française d'histoire d'outre-mer, 75, nº 280 (1988): 309-346.

Bouche, Denise. Histoire de la colonisation française, Tome second : Flux et reflux (18151962). Paris: Fayard, 1991.

Brunschwig, Henri. Mythes et réalités de l’impérialisme colonial français, Paris: Armand Colin, 1960.

Cantier, Jacques and Eric Jennings (dir.). L'Empire colonial sous Vichy, Paris: Odile Jacob, 2004.

Clayton, Anthony. France, Soldiers and Africa. Brassey's Defense Publishers Ltd, 1988. Histoire de l'armée française en Afrique 1830-1962, Paris: Albin Michel, 2014.

Frémeaux, Jacques. Les colonies dans la Grande Guerre, Paris: Editions 14-18, 2006.

CNRS Editions, 2010.

De quoi fut fait l'Empire. Les guerres coloniales au XIX siècle. Paris:

Jennings, Eric. Vichy in the Tropics: Pétain's National Revolution in Madagascar, Guadeloupe, and Indochina, 1940-1944, Stanford University Press, 2001.

Thobie, Jacques, Gilbert Meynier, Catherine Coquerey-Vidrovith and Charles-Robert Ageron. Histoire de la France coloniale 1914-1990, Paris: Armand Colin, 1990.

\section{North Africa}

Ageron, Charles-Robert. Histoire de l'Algérie Contemporaine. Tome II : De l'insurrection de 1871 au déclenchement de la guerre de libération. Paris: PUF, 1979.

Ageron, Charles-Robert. Histoire de l'Algérie Contemporaine, Paris: PUF, collection QSJ, 1990.

Bouchène, Abderrahmane, Jean-Pierre Peyroulou, Ouanassa Siari, Tengour and Sylvie Thénault (eds). Histoire de l'Algérie à la période coloniale (1830-1962), Alger: Barzach \& Paris: La Découverte, 2012.

Chouikha, Larbi and Eric Gobe. Histoire de la Tunisie depuis l'indépendance, Paris: La Découverte, coll. Repères, 2015.

Collot, Claude. Les institutions de l'Algérie durant la période coloniale (1830-1962). Paris: CNRS \& Alger: Office des publications universitaires, 1987.

Connelly, Matthew. A Diplomatic Revolution: Algeria's Fight for Independence and the Origins of the Post-Cold War Era. New York: Oxford University Press, 2002.

Germouni, Mohamed. Le protectorat français au Maroc, Paris: L’Harmattan, 2015.

Grangaud, Isabelle and M'hamed Oualdi. "Tout est-il colonial dans le Maghreb ? Ce que les travaux des historiens modernistes peuvent apporter”, L’Année du Maghreb 10 (2014): 233254. 
Julien, Charles-André. Histoire de l'Algérie contemporaine. Tome I : La conquête et les débuts de la colonisation. Paris: PUF, 1964.

Katan Bensamoun, Yvette. Le Maghreb : De l'empire ottoman à la fin de la colonisation française, Paris: Belin, 2007.

Martin, Jean-Philippe. Histoire de la Tunisie contemporaine. De Ferry à Bourguiba. Paris: L'Harmattan, 2003.

Masri, Safwan M. Tunisia. An Arab Anomaly. Columbia University Press, 2017.

McDougall, James. A History of Algeria. Cambridge University Press, 2017.

Rivet, Daniel. Le Maghreb à l'épreuve de la colonisation, Paris: Hachette, coll. Pluriel, 2002. . Histoire du Maroc de Moulay Idris à Mohamed VI, Paris: Fayard, 2012.

Stora, Benjamin. Histoire de l'Algérie coloniale (1830-1954). Paris: La Découverte, 1991. . Histoire de la guerre d’Algérie (1954-1962). Paris: La Découverte, 1992.

Valensi, Lucette. Le Maghreb d'avant la prise d’Alger. Paris: Flammarion, 1969.

\section{Sub-Saharan Africa}

Almeida-Topor, Hélène. L'Afrique au XXè siècle. Paris: Armand Colin, 1999.

Cooper, Fredrick. Decolonization and African Society. The labor question in French and British Africa, Cambridge University Press, 1996.

. Citizenship between Empire and Nation. Remaking France and French Africa 1945-1960, Princeton University Press, 2014. French edition: Français et Africains? Etre citoyen au temps de la décolonisation, Paris: Payot.

Guillemin, Philippe. "Les élus d'Afrique noire à l'Assemblée nationale sous la Quatrième République”, Revue française de science politique, 8, n4 (1958): 861-877.

Coquery-Vidrovitch, Catherine and Henri Moniot. L'Afrique Noire, de 1800 à nos jours. Paris: PUF, 1974.

Manning, Patrick. Francophone Sub-Saharan Africa. Cambridge University Press, 1998.

Randrianja, Solofo and Stephen Ellis. Madagascar. A Short History. London: Hurst \& Company, 2009.

Reid, Richard J. A History of Modern Africa, 1800 to Present. Wiley-Blackwell, 2012.

M’Bokolo, Elikia. Afrique Noire, Histoire et civilisations du XIXè siècle à nos jours, Paris: Hatier, 1992.

\section{Economic History}

Almeida-Topor, Hélène. Histoire économique du Dahomey (Bénin), 1890-1920, vol. 1 \& 2. Paris: L’Harmattan, 1995.

Amin, Samir. L'économie du Maghreb. La colonisation et la décolonisation. Paris: Editions de Minuit, 1966.

Amin, Samir. L'Afrique de l'Ouest bloquée. L'économie politique de la colonisation 18801970, Paris: Editions de Minuit, 1971. 
Andersson, Jens. "State Capacity and Development in Francophone West Africa", Lund Studies in Economic History No 86, University of Lund, 2018.

Barbe, Adam. When France Used the Public Debt to Colonise Morocco, Orient XXI (2017). http://orientxxi.info/magazine/when-france-used-the-public-debt-to-colonise-morocco,1719

Bassino, Jean-Pascal, Jean-Dominique Giacometti and Konosuke Odaka (eds). Quantitative Economic History of Vietnam 1900-1990. An International Workshop, Nishi-Futsu Kaikan /Maison Franco-Japonaise, Tokyo, Institute of Economic Research, Hitotsubashi University, 2000.

Berthélemy Jean-Claude. "L'économie de l'Afrique occidentale française et du Togo, 19461960”, Revue française d'histoire d'outre-mer, 67, n² 248-249, 1980: 301-337.

Bonzom, Lucien. Du régime fiscal en Algérie. Ses conséquences sur la situation et le développement économique de cette colonie. Thèse pour le doctorat ès Sciences politiques et économiques, Université de Paris, Faculté de droit, Paris: Arthur Rousseau, 1899.

Brocheux, Pierre and Daniel Hémery. Indochine, la colonisation ambigüe 1868-1954, Paris: La Découverte, 1994 [2nd ed. 2001].

Brocheux, Pierre. Une histoire économique du Vietnam 1850-2007. La palanche et le camion. Paris: Les Indes Savantes, 2009.

Cooper, Frederick. Africa since 1940: The Past of the Present, Cambridge: Cambridge University Press, 2002.

Press, 2014.

. Africa in the World. Capitalism. Empire. Nation-State, Harvard University

Coquery-Vidrovitch, Catherine. Le Congo au temps des grandes compagnies concessionnaires, Paris: EHESS, 1972 [2nd edition 2011].

Douël, Martial. Un siècle de finances coloniales, Paris: Librairie Félix Alcan, 1930.

Fall, Babacar. Le travail forcé en Afrique occidentale française (1900-1946). Paris: Karthala, 1993.

Fremigacci, Jean. Etat, économie et société coloniale à Madagascar (De la fin du XIXè siècle aux années 1940). Paris: Karthala, 2014.

Frankema, Ewout and Marlous van Waijenburg. "Metropolitan Blueprints of Colonial Taxation? Lessons from Fiscal Capacity Building in British and French Africa, 1880-1940." Journal of African History, 55, n 3 (2014): 371-400.

Huillery, Elise. “The Black Man’s Burden: The Cost of Colonization of French West Africa”, Journal of Economic History, 74, n 1 (2014): 1-38.

Hopkins, Anthony G. An Economic History of West Africa, New York: Columbia University Press, 1973.

Marseille, Jacques. Empire colonial et capitalisme français. Histoire d'un divorce. Paris: Albin Michel, 1984 [2nd edition 2005]

Nicolaï, André. “Tunisie : fiscalité et développement”, Tiers-Monde, 3, nº 11 (1962): 429-478.

Nouschi, André. "En Algérie : portrait social de la colonisation”, Annales, Économies, Sociétés, Civilisations, 20, nº 6 (1965): 1242-1252.

Polanyi, Karl. Dahomey and the Slave Trade. Seattle \& London: University of Washington Press, 1966. 
Saul, Samir. Intérêts économiques français et décolonisation de l'Afrique du Nord (19451962), Genève: Librairie Droz, 2016.

Suret-Canale, Jean. Afrique Noire, l'ère coloniale 1900-1945, Paris: Editions Sociales, coll. Terrains, 1962.

Tertrais, Hugues. La piastre et le fusil : le coût de la guerre d'Indochine, 1945-1954, Vincennes: Institut de la gestion publique et du développement économique, 2002.

Todd, David. "The impôts arabes: French Imperialism and Land Taxation in Colonial Algeria, 1830-1919”. In Tiley, John (ed.), Studies in the History of Tax Law: Volume 3, edited by John Tiley, 113-138. Oxford: Hart Publishing, 2009. 


\section{Fiscal Capacity and Dualism in Colonial States: The French Empire 1830-1962 Data appendix}

This version: June 2019

\section{TABLE OF CONTENTS}

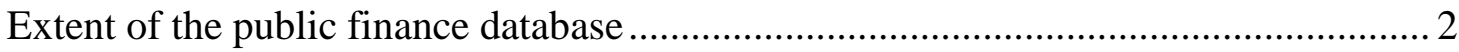

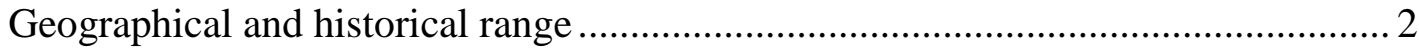

Budget accounts considered and sources used ..................................................... 4

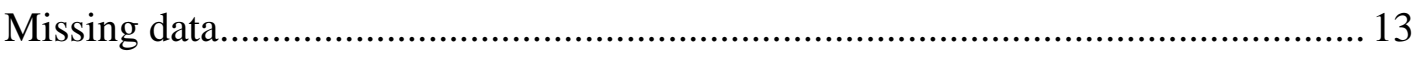

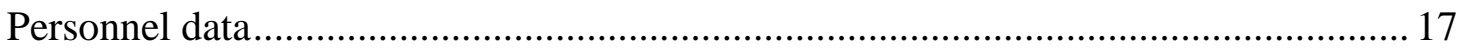

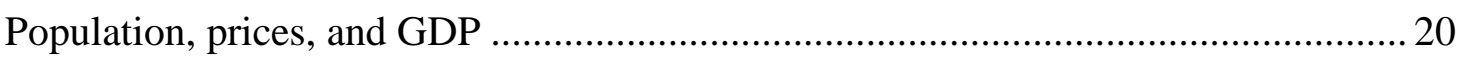

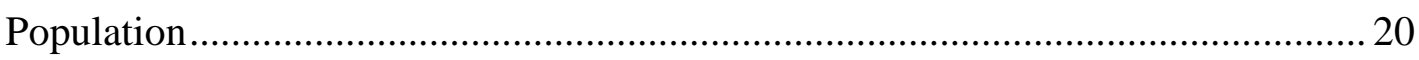

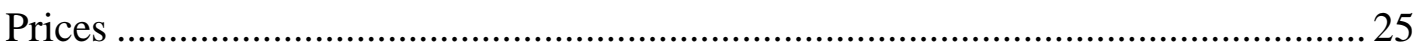

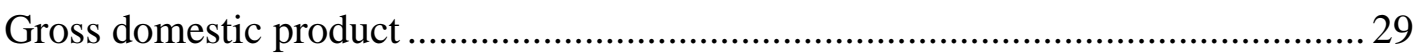

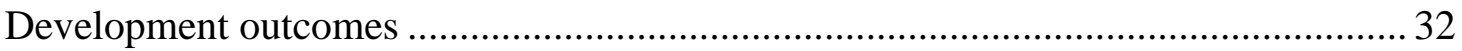

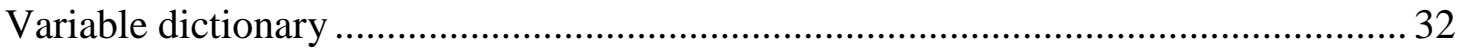

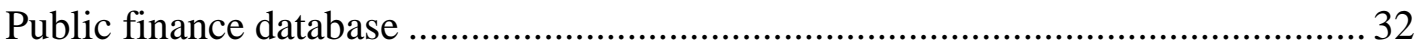

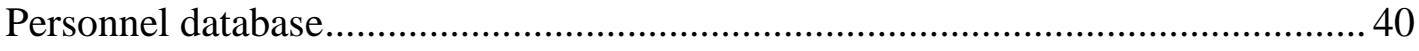

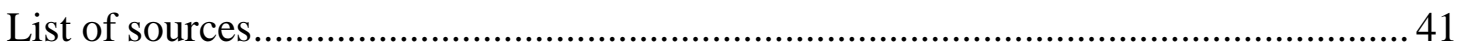

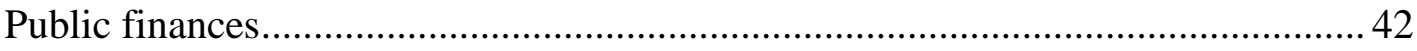

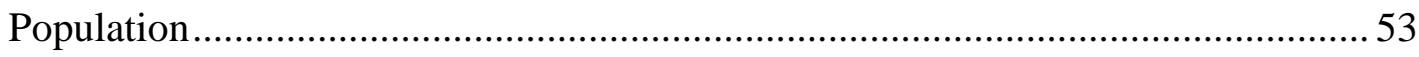

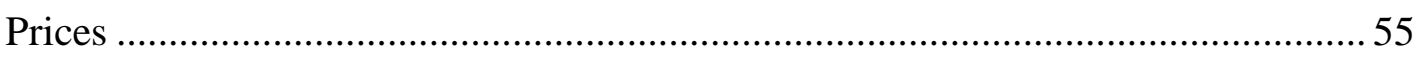

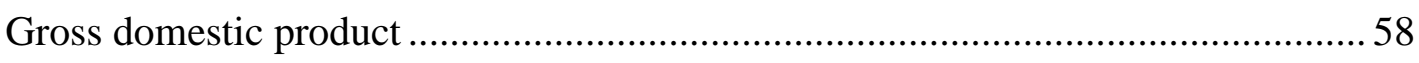

Development outcomes, imports and exports …............................................... 58

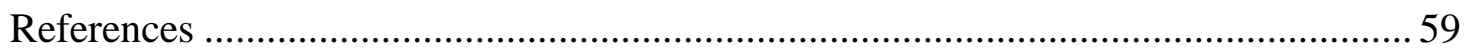




\section{EXTENT OF THE PUBLIC FINANCE DATABASE}

\section{GEOGRAPHICAL AND HISTORICAL RANGE}

Geographical range. Our database covers almost the entire second French colonial empire, corresponding to the second wave of European colonisation from the middle of the 19th century. Except the Indochinese Union, most colonies are in Africa: Algeria, Tunisia and Morocco, the federations of French West Africa (Afrique occidentale française, AOF) and French Equatorial Africa (Afrique Equatoriale Française, AEF), Togo, Cameroon, and

Figure 1: Geographical extent of the dataset

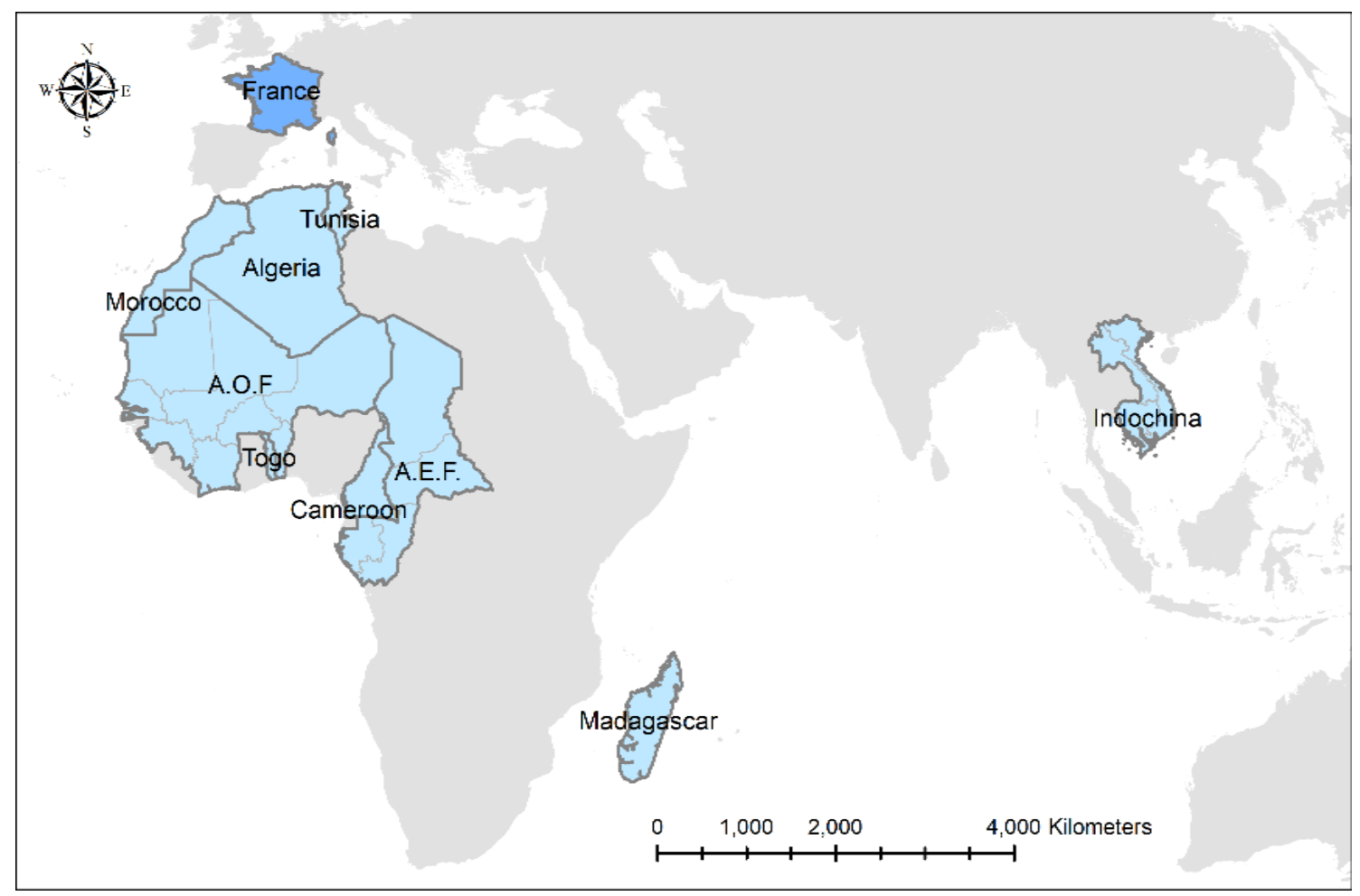

Madagascar (see map on figure 1). Our database does not encompass smaller colonial territories such as the remains of the first colonial empire (Guadeloupe and Martinique in the West Indies, French Guyana, the Reunion Island and the five trade posts of India), New Caledonia, colonized by France in 1853, and the port of Djibouti, colonized in 1884. Lebanon and Syria, under French rule between the two world wars, are not included in the present database either. In total, the former French colonies that are part of our database correspond to 21 contemporary countries: Algeria, Morocco, and Tunisia in North Africa, Benin, Burkina- 
Faso, Cameroon, Chad, Central African Republic, Congo-Brazzaville, Côte d’Ivoire, Gabon, Guinea, Madagascar, Mali, Mauritania, Niger, Senegal and Togo in Sub-Saharan Africa, and Vietnam, Laos and Cambodia in South-East Asia.

Table 1: Historical range of the dataset

\begin{tabular}{|c|c|c|c|c|}
\hline Region & $\begin{array}{l}\text { Range of } \\
\text { colonial data }\end{array}$ & \# observations & $\begin{array}{l}\text { Range of Franc } \\
\text { Zone data }\end{array}$ & \# observations \\
\hline Algeria & $1833-1958$ & 96 & 1959-1969 & 11 \\
\hline Morocco & $1915-1956$ & 41 & 1957-1969 & 13 \\
\hline Tunisia & 1891-1955 & 61 & 1956-1969 & 13 \\
\hline Indochina & $1871-1953$ & 40 & & \\
\hline West Africa ${ }^{(a)}$ & 1905-1958 & 18 & 1959-1967 & 9 \\
\hline Equatorial Africa ${ }^{(b)}$ & 1904-1954 & 22 & $1958-1970$ & 13 \\
\hline Cameroon & $1922-1957$ & 28 & $1958-1970$ & 13 \\
\hline Madagascar & 1901-1956 & 52 & $1958-1970$ & 13 \\
\hline Togo & $1920-1956$ & 14 & $1958-1970$ & 13 \\
\hline
\end{tabular}

(a) The West African federation includes Côte d'Ivoire, Dahomey (present Benin), Guinea, Haute-Volta (present Burkina-Faso), Mauritania, Niger, Senegal and Soudan (present Mali).

(b) Equatorial Africa includes Chad, Congo (present Congo-Brazzaville), Gabon, Oubangui-Chari (present Central African Republic)

Historical range. For each territory, the starting date depends on the specific history of colonization in the region and on the date at which colonial authorities started producing systematics records of public finances. The first region to be colonized was Algeria, whose conquest began in 1830, the last were Togo and Cameroon, who were given to France as League of Nation mandates after WWI. The end date also depends on the specific history of each region. In Indochina, our database stops in 1953, one year before independence. For African colonies, which became independent between 1956 (independence of Morocco) and 1962 (independence of Algeria after an eight year war), we are able to extend the database to the end of the 1960s, using the reports of the Franc Zone, the monetary union between France and some of its former colonies. Since the 1950s, the Banque the France in charge of the monetary policy of the Franc Zone has been publishing reports containing some information on the public finances of its member countries. These reports offer a picture of public revenue and expenditure less detailed and complete than the one built using budget accounts directly. Table 1 sums up, for each of the 9 regions considered, the historical range of our public 
finance data, distinguishing between the "colonial” dataset, built primarily from budget accounts, and the "Franc Zone” dataset, built primarily from the reports of the Franc Zone.

\section{BUDGET ACCOUNTS CONSIDERED AND SOURCES USED}

This section presents the budget accounts considered and the sources used to build the public finance database, as well as the main assumptions made, especially when dealing with missing data. The complete list of sources is displayed in the "Public finances" section of the "List of sources" below. In order to produce figures comparable across time and across regions, we did not only consider the central colonial governments, but tried to collect data for all public authorities responsible for revenue and expenditure in the colonies. This requires detailed knowledge of the administrative structure of the Empire. We collected data from various budget accounts: metropolitan (French), colonial, federal in colonies organised in federations, auxiliary (loan budget accounts, development funds, etc.), as well as the accounts of lower level administrative divisions. For each year and each region of the Empire, these budgets are consolidated, meaning that the various transfers between them (subsidies, loans, interests and reimbursements) are cancelled out to avoid double counting of revenue and expenditure items.

Metropolitan budget accounts. In Metropolitan France, two ministries were responsible for most of the spending in the colonies: The Ministry of the Navy and the Colonies (Ministère de la Marine et des Colonies), and the Ministry of War (Ministère de la Guerre). Military expenditure in the colonial Empire were the responsibility of these ministries (the ministry of war dealt with North Africa, the ministry of the colonies with the rest of the Empire). Military expenditure therefore never appear in the colonial budget accounts, except in Algeria between 1830 and 1900 (and between 1904 and 1937 for the Southern Territories only), in Morocco until 1937, and again in 1956 in preparation for independence, and in Indochina in $1953 .{ }^{1}$ It is not obvious whether colonial military expenditure of metropolitan budget accounts should be considered an item of expenditure for the colonies. On the one hand, countries started developing a national defense budget once they became independent, and colonial military expenditure could be partly considered as France mutualizing the cost of national defense. On the other hand, the military conquest and

\footnotetext{
${ }^{1}$ More precisely, in the national budgets of Vietnam, Laos and Cambodia, and in the regional budget of North Vietnam (Tonkin). Total security expenditure is not broken down between civilian and military, but personnel expenditure is. We use the share of military in personnel expenditure to infer total military expenditure from total security expenditure.
} 
domination of a colonial empire should be considered mainly an item of expenditure for France, the colonizing power. Additionally, military expenditure of the Ministry of Colonies includes the payment of colonial troops who contributed to France's national defense by fighting in Europe during WWI and WWII. In the end, we exclude military expenditure from

Figure 2: Share of various budgets in civilian public expenditure (North Africa and Indochina)
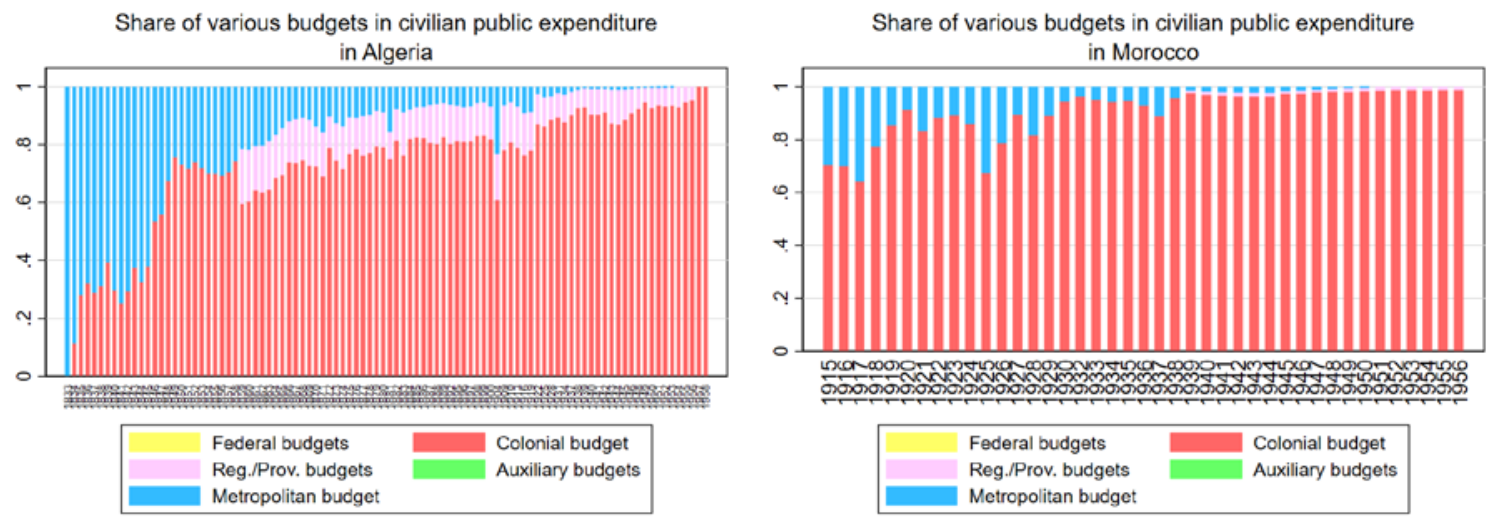

Share of various budgets in civilian public expenditure in Tunisia
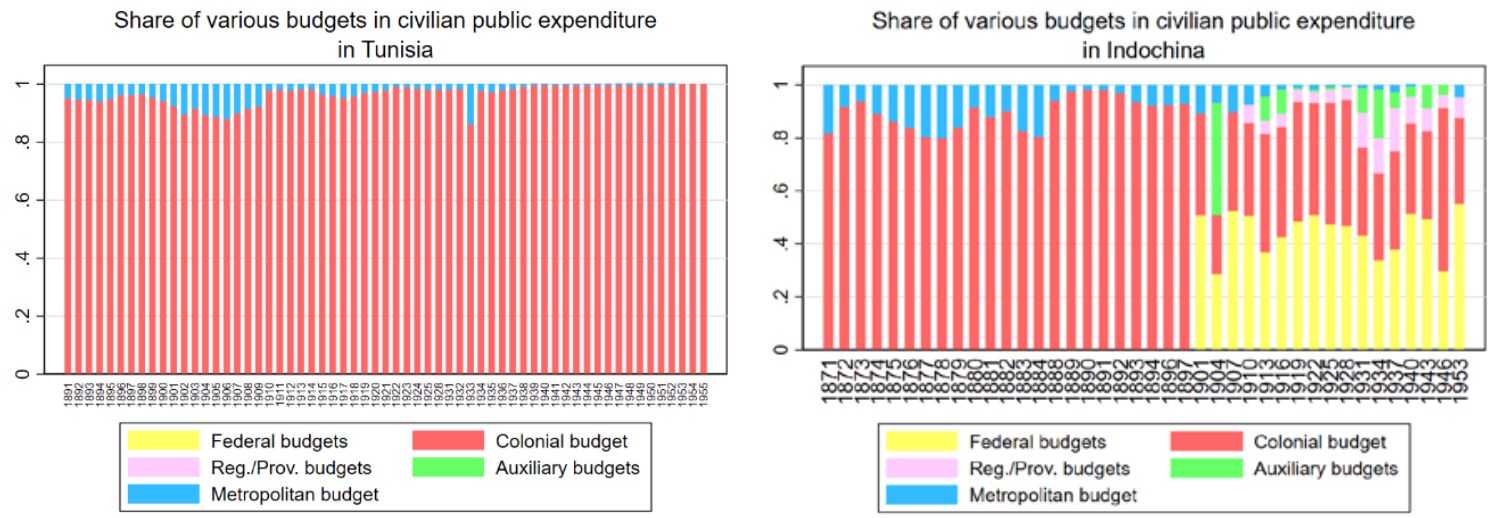

Note: the quasi-absence of auxiliary budgets in North Africa (Algeria, Morocco, Tunisia) reflects the fact that, in these colonies, auxiliary and colonial budgets were often presented alongside each other and were merged during data collection.

our public expenditure aggregate, and make colonial military expenditure available separately (see "Variable dictionary” below). However, our public expenditure aggregates do comprise expenditure of the Ministries of War and Colonies that can be thought of as civilian in nature, namely subsidies to private companies, and infrastructure and health expenditure. Only during the period of conquest, and in Indochina, did this Metropolitan expenditure represent more than a couple of percentage points of our aggregate civilian expenditure figure (see figures 2 and 3). Only part of this Metropolitan civilian expenditure can be allocated to a given region of the empire. We allocated the rest in proportion of the share of each region in allocated 
expenditure. $^{2}$ On the revenue side, we consider this as direct subsidies from France to its colonies.

Figure 3: Share of various budgets in civilian public expenditure (Sub-Saharan Africa)
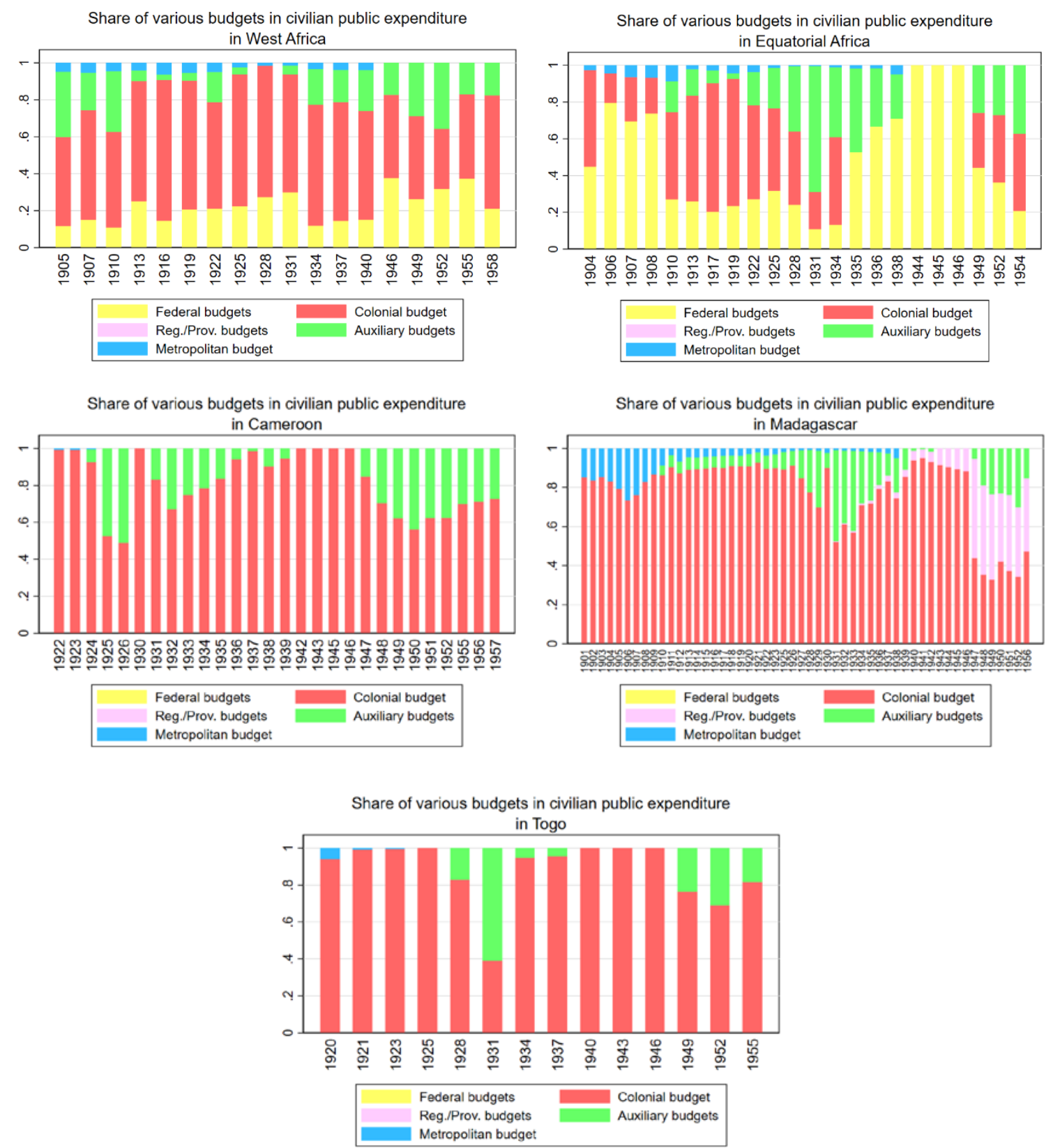

From 1958 to 1962, there was a ministry in France in charge of the Sahara region (Ministère du Sahara). Its expenditure was added to the Algerian public expenditure available

\footnotetext{
${ }^{2}$ The share of each region in allocated expenditure was computed over 10-year periods. In the budget accounts of the Ministry of the Colonies, regional allocation is not known at all between 1932 and 1959. We use allocated expenditure using the regional allocation of the 1920s. In the budget accounts of the Ministry of War, figures are aggregated for Tunisia and Algeria in 1915, 1921, 1928-1929 and 1933-1937: we allocate between Tunisia and Algeria using average allocation in the 1920s. In 1938 and 1939, figures are given for the whole of North Africa. We allocate between Algeria, Tunisia and Morocco using average allocation in the 1920s.
} 
in the Franc Zone Reports and, on the revenue side, counted as a subsidy of Metropolitan France to Algeria. Other ministries were in charge of Morocco and Tunisia (Ministère des affaires marocaines et tunisiennes, 1955-1959) and of Algeria (Secrétariat d'Etat aux affaires algériennes, 1958-1963), but their expenditure already appears in the colonial budget accounts and the Franc Zone reports.

Federal structure. Three regions of the empire, Indochina, French West Africa (Afrique Occidentale Française, AOF) and French Equatorial Africa (Afrique Equatoriale Française, AEF), were organized in federations. The AOF federation was created in 1895. In 1922, it included eight colonies: Senegal, Soudan (present-day Mali), Guinea, Côte d’Ivoire, Dahomey (present-day Benin), Mauritania, Haute-Volta (present-day Burkina Faso) and Niger. $^{3}$ Between 1932 and 1946, the Haute-Volta colony disappeared and its territory was divided between Côte d'Ivoire and Niger. The AEF federation was created in 1910 and included four colonies: Congo, Gabon, Chad, and Oubangui-Chari (present-day Central African Republic). The Indochinese Union was created in 1887 and included Cochinchina (South Vietnam), Annam (Central Vietnam), Tonkin (North Vietnam) and Cambodia. Laos was added in 1899. The Indochinese Union became the Indochinese Federation in 1946 and was dissolved in 1949. The AOF and AEF were dissolved in 1958-59. ${ }^{4}$

These federations were organized in a pyramidal structure, with colonial governments (Gouvernements locaux) in each colony, responsible for local revenue and expenditure, and a federal government (Gouvernement général) responsible for general interest spending (mostly in infrastructure and administration) and financed mostly by custom duties and rents on government monopolies. Within a federation, there were many financial transfers (loans, advances, subsidies) between the different colonies and the federal government. Federal revenue and expenditure represented a large share of total revenue and expenditure (see figures 2 and 3 for the expenditure side). For that reason, we consider these federations as a whole and do not attempt to reallocate federal revenue and expenditure to the different colonies that were to become autonomous republics or independent countries. In a given federation in a given year, consolidated expenditure (revenue) is obtained by summing expenditure (revenue) in the federal budgets and the various colonial budgets, cancelling the

\footnotetext{
${ }^{3}$ New colonies were added progressively as the French were conquering more and more territories. The borders of colonies also kept evolving. Before World War I, Soudan, Niger and Haute-Volta were forming the colony of "Haut-Sénégal-Niger."

${ }^{4}$ Indochina was divided in three "Associated States” (Cambodia, Laos, and Vietnam). Colonies of AOF and AEF became autonomous Republics belonging to the French Community, a political association of France and its former African colonies, except Guinea which became independent in 1958. The French Community was dissolved in 1960 when all French colonies south of the Sahara gained independence.
} 
transfers within the federation. ${ }^{5}$ Though the federations of AOF and AEF were dissolved in 1958, there was residual expenditure and revenue until 1959, recorded in the Franc Zone report for 1959 (France, Comité monétaire de la zone franc, 1959). In the same report we found the revenue and expenditure of the short-lived Mali Federation, which united Mali and Senegal between 1959 and 1960 .

Auxiliary budgets. Infrastructure projects financed by loans were often registered on separate auxiliary budgets. Ports, railways, and the health sector also sometimes saw their expenditure and revenue recorded in a separate budget. Because railway companies were not always public, we did not collect data from the auxiliary budgets of railways. In the case of a public railway company, excess revenue was transferred to the colonial budget and is taken into account in our data (in the category "Monopoly revenue", see "Variable dictionary" below), subsidies to the railway company were also recorded in the colonial budget and are taken into account in our data (in the category "Production support"). Capital expenditure for the construction of railway lines was mostly financed publicly and appears in the colonial budgets rather than the railway budgets. Posts and telegraphs, which were always public, are fully taken into account in our aggregates: their receipts are in the variable "Monopoly revenue", and their expenditure in the variable "Production support". ${ }^{6}$ As for the various development plans established in the 1950s, their accounts sometimes appear directly in the colonial budget, as is the case for the Constantine plan in Algeria, and are sometimes recorded in special budgets managed directly by France, as is the case for the special development fund created for Sub-Saharan Africa, the FIDES (Fonds d'Investissement pour le Développement Economique et Social). The expenditure of the FIDES in each year and each colony was found in a retrospective document published by IEDES (1964). On the revenue side, because the FIDES was financed only by contributions from France and from the colonies, we were able to reconstitute the French subsidy by subtracting the colonies' contributions from the total expenditure. ${ }^{7}$

First and second-level administrative divisions. Below the colony (corresponding to present-day countries), we consider first-level (districts) and second-level (municipalities) administrative divisions. The level of decentralization of public expenditure varied within the

\footnotetext{
${ }^{5}$ Each colony of a federation had its own colonial budget, except in AEF between 1935 and 1945, where all revenue and expenditure items were written in the federal budget.

6 The receipts and expenditure of the posts and telegraphs are usually recorded in the colonial budget, but in Algeria from 1925, they are recorded in a separate budget, available at the Bibliothèque nationale de France between 1925 and 1939. We rely on the summary provided in the statistical yearbooks afterwards (see "List of sources").

${ }^{7}$ The French contributions are also recorded in the French budgets, but in a less systematic way.
} 
French colonial Empire. It was very low in West and Equatorial Africa, and more important in North Africa, Madagascar, and Indochina.

Our figures always take into account first-level administrative divisions. Algerian départements (district) started having distinct budgets in 1859, Malagasy provinces in 1931, and Moroccan régions in 1939. In Indochina, we use the provincial budget accounts of Cochinchina from 1910 on, and all provincial budgets starting in 1931, when a number of items of revenue and expenditure were decentralized from colonial to provincial budgets. In Tunisia, AOF, AEF, Togo, and Cameroon, first-level administrative divisions (districts) did not have budgets of their own. We can see on figure 2 and 3 that the share of first-level administrative divisions in total expenditure was significant only in Algeria, Indochina, and Madagascar. In Madagascar, the contribution of provincial budgets to total public expenditure became particularly important after the decentralization reform of 1946 , reaching $50 \%$ in some years.

Table 2: Share of municipalities in total net expenditure and revenue

\begin{tabular}{lcccc}
\hline & \multicolumn{2}{c}{1925} & \multicolumn{2}{c}{1955} \\
& $\begin{array}{c}\text { Share in } \\
\text { expenditure }\end{array}$ & $\begin{array}{c}\text { Share in } \\
\text { revenue }\end{array}$ & $\begin{array}{c}\text { Share in } \\
\text { expenditure }\end{array}$ & $\begin{array}{c}\text { Share in } \\
\text { revenue }\end{array}$ \\
\cline { 2 - 5 } Algeria & $23.6 \%$ & $20.5 \%$ & $21.2 \%$ & $24.4 \%$ \\
Morocco & n.a. & n.a. & $7.8 \%$ & $11.4 \%$ \\
Tunisia & $9.1 \%$ & $13.7 \%$ & $6.3 \%$ & $7.5 \%$ \\
W. Africa & $4.9 \%$ & $0.2 \%$ & n.a. & n.a. \\
Indochina & $1.1 \%$ & $1.0 \%$ & n.a. & n.a. \\
France & $33.1 \%$ & n.a. & $13.6 \%$ & n.a. \\
\hline
\end{tabular}

Sources for France: André et Delorme (1983), INSEE (1966)

Second-level administrative divisions (municipalities) had distinct budgets in NorthAfrica and Indochina. In Sub-Saharan Africa, no municipality was empowered to raise revenue and allocate expenditure before 1955, with the exception of the four Senegalese communes which obtained the same status as metropolitan municipalities: Saint-Louis and Gorée (in 1872), Rufisque (in 1880), and Dakar (in 1887). In 1955, 44 new municipalities 
were created in AOF, AEF, Madagascar, Cameroon and Togo. ${ }^{8}$ We found some budget accounts for second-level administrative divisions, but our series are patchy and incomplete. They are therefore not included in our main aggregates, though we make them available in a separate variable (see "Variable dictionary”). Table 2 displays the share of municipalities in total public expenditure and revenue for North Africa, West Africa, Indochina, and France. Municipalities were particularly important in North Africa. In 1955 for instance, they represented $7.5 \%$ of revenue in Tunisia, $11.4 \%$ in Morocco, and $24.4 \%$ in Algeria. In the rest of the Empire, municipalities did not weigh as much. In 1925, they represented $0.2 \%$ of revenue and less than $5 \%$ of expenditure in West Africa, and about $1 \%$ of expenditure and revenue in Indochina (we could not find data for 1955).

Figure 4: Distribution of revenue and expenditure in excess of provision
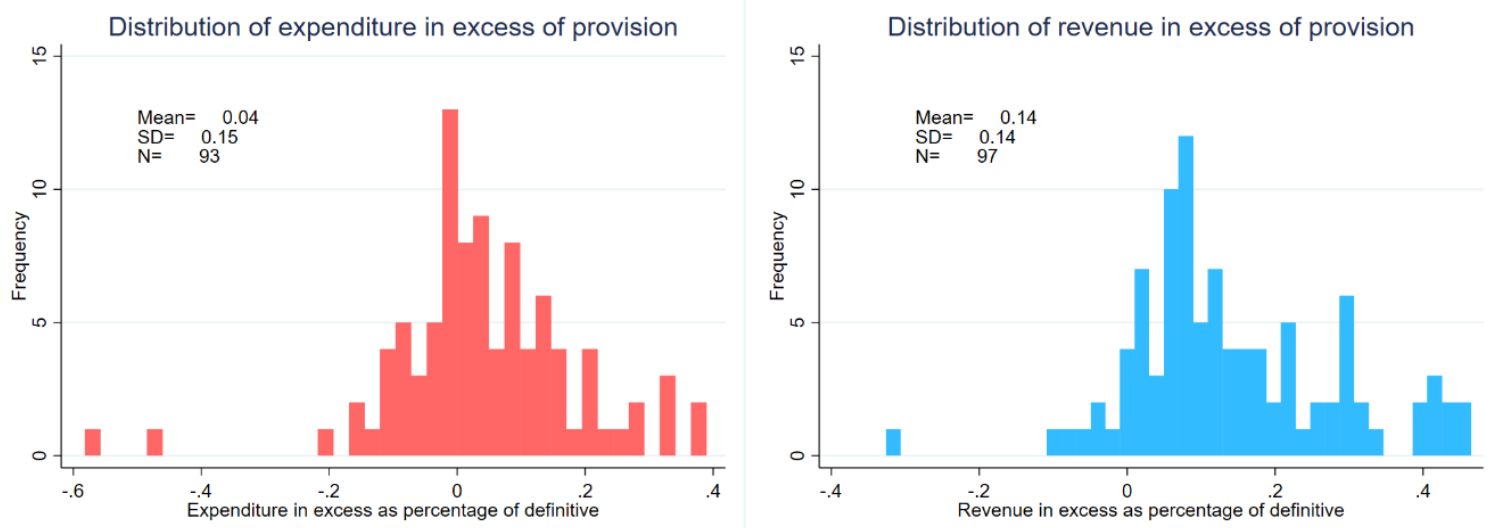

Definitive and provisional accounts. Several types of documents were produced during the budget process: provisional accounts (usually called "Budgets”) were previsions produced in advance of the fiscal year, while definitive accounts (usually called "Comptes défnitifs") were published after the end of the fiscal year and recorded the actual amounts collected and spent. Whenever possible, we rely on definitive accounts, but use provisional accounts in a few years when definitive accounts are missing. Provisional accounts are typically much more detailed, and notably contain information on wages and the number of employees, which is why we also use them to collect information on average public sector wages and the size of the civil service (see "Personnel data" below). For the 97 colony-years in common between the two datasets, we can check the discrepancy between provisional and definitive accounts: provisional accounts underestimate final expenditure by $4 \%$ on average and final revenue by $14 \%$ on average (figure 4). When provisional or definitive accounts are

${ }^{8}$ France. Journal official de la République française du 19 novembre 1955. Paris: Imprimerie des Journaux officiels, 1955, p. 11274. https://www.legifrance.gouv.fr/jo_pdf.do?id=JORFTEXT000000313008 
not available, we sometimes use Statistical Yearbooks (Annuaires Statistiques) or other official publications, which present definitive figures (see the "list of sources" below).

Social security. Though social security transfers are not part of our main aggregates, we provide separate figures for social security contributions and benefits. There was no social security in the French colonial Empire before 1945. After 1945, social security funds were introduced in the settler colonies of Algeria, Morocco and Tunisia, but not in the colonies of Sub-Saharan Africa and Southeast Asia. ${ }^{9}$ The accounts of various social security funds were found in the statistical abstracts of the relevant colonies.

Postcolonial data. To extend the dataset to the postcolonial period, we use mainly the reports of the Monetary Committee of the Franc Zone (Comité Monétaire de la Zone Franc, various dates), and the OECD development assistance committee (OECD-DAC) data (OECD, 2017). The information contained in the Franc Zone reports is not as detailed as the information contained in the budget accounts of various colonies. In consequence, after independence, aggregate revenue net of subsidies and loans cannot systematically be broken down into different tax instruments, and aggregate expenditure net of subsidies and loans cannot systematically be broken down into different sectors. Guinea gained its independence from France in 1958 and cut ties with the former colonizer, refusing to be part of the monetary union headed by France. As a result, Guinean public finances are not recorded in the Franc Zone reports, and we use the figures given in Amin (1971) instead.

Table 3: Development expenditure in the 1960, comparison of different sources

\begin{tabular}{lcc}
\hline \multicolumn{1}{c}{ (current FCFA billions) } & Development $\operatorname{plan}^{(1)}$ & Franc zone report $^{(2)}$ \\
\hline Senegal (1969) & 10.92 & 4.66 \\
Haute-Volta(1967-1970) & 19.76 & 3.30 \\
Madagascar (1964-1966) & 39.38 & 21.52 \\
\hline
\end{tabular}

(1) Sources: Haute-Volta, Direction du plan et des études de développement (1971); Madagascar, Commissariat général au plan (1965-69); Sénégal, Secrétariat d'Etat au plan (1972).

(2) Sources : Comité monétaire de la Zone Franc (various dates)

One other important limitation of the Franc Zone reports is that they do not systematically take into account the budgets of various development funds. This is not a

${ }^{9}$ Algeria had a family allowance fund (Caisse d'allocations familiales) and a social security fund (Caisse de sécurité sociale). Morocco had a help fund (Caisse d'aides) later renamed social security fund (Caisse de sécurité sociale). Tunisia had a family allowance fund (Caisse d'allocations familiales). 
problem to estimate fiscal revenue, as these funds were typically financed by loans and aid, but this is a problem to estimate net expenditure. Table 3 compares development (capital) expenditure in the few development plans budget accounts we were able to find with development expenditure in the Franc Zone reports in the corresponding years. Franc Zone reports appear to systematically miss a large share of development expenditure, about half in Senegal (1969) and Madagascar (1964-1966), more than 80\% in Haute-Volta (present-day Burkina Faso) between 1967 and 1970.

To approximate development expenditure in the 1960s, we assume that they were mostly financed by international aid (grants and loans) and complement the Zone Franc reports with the OECD-DAC dataset. Net public expenditure in a given country after 1960 is computed as total expenditure minus debt service as recorded in Franc Zone reports, minus all external loans and subsidies received by the country recorded in the Franc Zone report (except when we know these emanate from a private source or a non-OECD country), plus net OECD ODA (loans and grants) received by the country. ${ }^{10}$ This does not affect our measure of net revenue, which is simply the sum of fiscal revenue and revenue of industrial operations, domains and monopolies recorded in the Franc Zone reports. ${ }^{11}$

There are other discrepancies between the series built using colonial budget accounts and the postcolonial series. Franc Zone reports to not record the auxiliary accounts of parastatal sectors such as posts and telecommunications. In Tunisia between 1961 and 1966, we were able to take into account the expenditure and revenue of the posts and telecommunications service recorded in the statistical yearbook of Tunisia 1964-1965 (Tunisia, Secrétariat d'Etat au plan et aux finances, 1964-1965). Franc Zone reports do not always take into account the revenue and expenditure of first-level administrative divisions. It is an important concern for Madagascar only, where the share of provinces in total public expenditure and revenue was quite high in the 1950s (see figure 3, panel 4). Malagasy provincial accounts are recorded in the Franc Zone reports until 1960. Between 1963 and 1966, we find them in Madagascar, Commissariat général au plan (1965-1969). Other years are extrapolated (see “Missing data” below).

\footnotetext{
${ }^{10}$ On top of aid to individual countries, the OECD-DAC dataset records regional aid allocated to world regions such as "Africa, South of Sahara” or “Africa, North of Sahara.” We allocate regional aid to each individual country in proportion of its share in total allocated aid. Before 1964, French aid to Sub-Saharan Africa is not broken down by individual countries at all. We allocate it to each individual country in proportion of its share in 1964 total allocated French aid to Sub-Saharan African countries.

11 As Franc Zone reports become less precise in the end of the 1960s, the revenue of industrial operations, domains and monopolies often becomes missing (fiscal revenue is always given). To avoid a break in the series, we extrapolate the revenue of industrial operations, domains and monopolies using their share in total net revenue the last year it was available.
} 
Comparison with Metropolitan France. For comparisons with Metropolitan France, we use the series on the expenditure of the central government and local governments (départements and communes) in André and Delorme (1983). For the years 1925 and 1955, we add the expenditure of posts and telegraphs from annual reports (see "list of sources" below). André and Delorme (1983) give the sectoral allocation of expenditure for the central government only. Their categorization is slightly different from ours, except for education. We allocate "public authorities" to general administration, "social action" to health, "transport” and "housing” to infrastructure, and "agriculture” and "trade and manufacturing” to production support, to which we add the expenditure of posts and telegraphs. We separate civilian expenditure from military expenditure (“defense” and "veterans”). We remove debt service to get as close as possible to our definition of Net (civilian) Public expenditure (see “variable dictionary” below). We assume that debt service represented $10 \%$ of the expenditure of local governments in 1925 and 5\% in 1955 (André and Delorme 1983, p. 75). André and Delorme (1983) also give figures for social security benefits. On the revenue side, we assume that social security contributions are equal to social security benefits.

Net public revenue and the fiscal structure of the central government in 1925 and 1955 is taken from INSEE (1966, p. 486-87) and from the annual reports of posts and telegraphs. Revenue of départements and communes is found in INSEE (1966, pp. 504-505, year 1923 for communes).

\section{MISSING DATA}

This section details the different assumptions and extrapolations made in order to consolidate various data and avoid breaks in statistical series when particular budget accounts could not be found.

Colonial budget accounts. For Algeria, Morocco, Tunisia, Indochina, Madagascar and Cameroon, we set up the goal of collecting data at an annual frequency, though we sometimes could not find budget accounts for a particular year. For the two African federations (AOF and AEF), we collected federal budget accounts (budgets généraux) every year, but colonial budget accounts (budgets locaux) every three years only. We also collected data on Togo every three years only. Aggregating expenditure and revenue at the level of the federation (AOF, AEF, and Indochinese Union) requires having the budget accounts of all the colonies of the federation in a given year. When we could not find the budget account of a 
colony, we used the account of an adjacent year. ${ }^{12}$ In rare cases, we could not find adjacent years: budget accounts of the colony of French Soudan (AOF, present day Mali) are missing between 1922 and 1928 and in 1946, the budget accounts of Gabon (AEF) are missing in 1947 and 1949, and the one of Oubangui-Chari (AEF) is missing in 1954. In these cases, we make an educated guess for the revenue and expenditure of the missing colony using its share in the total revenue and expenditure of the federation in a close enough year. ${ }^{13}$ For French Soudan in 1946, we know total revenue and expenditure (recapitulated in the 1949 budget), and we break them down into different items of revenue and expenditure using the distribution of 1949. We could not find the budget accounts of Haute-Volta in 1958, but we use the information recorded in the Franc Zone report for that year. We infer the sectoral allocation of expenditure, not given in the Franc Zone report, using the allocation of 1956.

There is some missing information in Morocco’s special budget (“Budget spécial”, an investment budget accounting for an average 7\% of total expenditure). Between 1926 and 1931, and in 1953, our source gives only revenue, and not expenditure. We set expenditure equal to revenue. Between 1932 and 1937, our source gives only the total expenditure of the special budget, and the sectoral allocation is not given. Between 1926 and 1937, we use the sectoral allocation of 1938. In 1953, we use the sectoral allocation of 1952.

Metropolitan budget accounts. In Metropolitan budget accounts (Ministry of the Colonies and Ministry of War) we collected, for each colonial territory, military expenditure, subsidies to private companies, infrastructure expenditure, and health expenditure. Residual expenditure was allocated to each category in proportion of its weight in allocated expenditure in the same year. Expenditure that was not allocated to a specific territory was allocated to each territory in proportion of its weight in geographically allocated expenditure. ${ }^{14}$ In years

12 In AOF, affected years and budget accounts are: Cote d'Ivoire (1917 instead of 1916 and 1926 instead of 1925), Dahomey (1944 instead of 1943 and 1957 instead of 1958), Haute Volta (1920 instead of 1919, 1929 instead of 1928, and 1954 instead of 1955), Niger (1942 instead of 1943), Senegal (1959 instead of 1958), French Soudan (1932 instead of 1931). In AEF: budget général (1903 instead of 1904), Gabon (1953 instead of 1954), Oubangui-Chari (1912 instead of 1913), Tchad (1912 instead of 1913). In Indochina: Annam (1945 instead of 1946), Cambodia (1945 instead of 1946), Cochinchina (1906 instead of 1907), Laos (1897 instead of 1896 and 1902 instead of 1901, 1945 instead of 1946), Tonkin (1945 instead of 1946), PMS region (1954 instead of 1953), municipalities (1942 instead of 1943).

${ }^{13}$ We use the shares of 1919 for French Soudan 1922 and 1925, the shares of 1931 for French Soudan 1928, the shares of 1955 for Togo and Haute Volta 1958, and the shares of 1952 for Gabon 1947 and 1949, and Oubangui-Chari 1954.

${ }^{14}$ For strictly military expenditure, the bulk of expenditure, we followed the geographical allocation of the same year. For subsidies to private companies, infrastructure and health expenditure, which are more volatile, we followed the average geographical allocation of the decade. 
were expenditure was not allocated geographically at all, we followed the geographical allocation of a close enough year. ${ }^{15}$

We collected Metropolitan budget accounts every year systematically from 1870 onwards. Before this date, we collected data every 3 years for the Ministry of War, and every 10 years for the Ministry of the Colonies. Budget accounts are also missing for a handful of years after 1870. In order to have consistent estimates, we filled in the missing years using linear interpolation. ${ }^{16}$ After 1939, budget accounts of the Ministry of War are missing for all years except 1946. We do not try to fill in the gap during World War II (1940-1945), when the North Africa was a battleground of the fight between Vichy France and Free France. ${ }^{17}$ We found the military expenditure of Metropolitan France in 1954, 1957 and 1961 Algeria in Amin (1966), and interpolated interim years using the number of soldiers present in Algeria (including conscripts, using Mahieu 2001). French military expenditure in 1953 Tunisia are also from Amin (1966), and we kept this figure constant in real terms until 1956. French military expenditure in 1951 Morocco are from Amin (1966). Between 1952 and 1956, we use balance of payments data (Morocco, 1960), assuming that $90 \%$ of the public expenditure paid by Metropolitan France were for the military. Though France fought the Cameroonian independentists starting in 1955 (Domergue et al. 2011), the cost of this "hidden war" does not appear isolately in the accounts of the Ministry of the Colonies. Because Cameroon was a trust territory of the U.N., France was in theory not allowed to undertake military expenditure there. We do not know whether the cost of the Cameroonian war is included in the total French colonial military expenditure.

As can be seen in figures 2 and 3, the direct, non-military expenditure of Metropolitan ministries was only important in the early colonial period (especially in Algeria), and gradually lost importance over time. Subsidies to colonial government were more important,

${ }^{15}$ In the budget accounts of the Ministry of the Colonies, the geographical allocation of expenditure is not given between 1932 and 1959 (except for Indochina 1950-54 and AOF 1950-51). We allocated military expenditure using the geographical allocation of 1931. For non-military expenditure (subsidies, health and infrastructure), we followed the geographical allocation of the period 1920-1931. In the budget accounts of the Ministry of War, the geographical allocation does not distinguish between Algeria and Tunisia in 1915, 1920-21, and 1928-1937. We allocated between the two territories using the proportions of 1914. In 1938 and 1939, the accounts of the Ministry of War give expenditure for the whole of North Africa. We allocated between Algeria, Morocco and Tunisia using the proportions of 1937. Finally, in 1946, the accounts of the Ministry of War give one figure for North Africa and the Middle East. We allocated between the different colonies using the proportions of 1939.

${ }^{16}$ Missing years are, for the Ministry of the Colonies, 1884, 1886 (AEF only), 1888, 1889, 1892, 1893, 1896 (Madagascar only), 1900 and 1945, and, for the Ministry of War, 1877-1879, 1889, 1892, 1902 (except Indochina), 1906, 1914 (Morocco only), 1916-1919, 1930, 1931.

${ }^{17}$ For the Ministry of the Colonies, responsible for military expenditure outside North Africa, our source (the statistical yearbook of the French Union) gives us expenditure during World War II, including the expenditure of Free France (comité français de la libération nationale), but strictly military expenditure are missing in 1940 and 1941. 
especially after 1945 (see main paper), but we do not rely on Metropolitan budget accounts to estimate them. Direct military expenditure of Metropolitan ministries were even more important (see main text), and it is important to keep in mind that, after 1939, our figures are only rough estimates.

First-level administrative divisions. We use linear interpolation to fill in gaps in our public finance series for first-level administrative divisions: Malagasy provinces between 1932 and 1937 and between 1960 and 1963, Cochinchinese provinces between 1923 and 1930, Algerian départements between 1938 and 1948, Moroccan régions between 1940 and 1944 and between 1946 and 1948. These assumptions are quite innocuous to our final aggregates because, except in Madagascar after WW2, these budget accounts never represent a large share of total public expenditure and revenue (figures 2 and 3). In Madagascar in 1952, the budget accounts of the province of Tananarive are missing: we make an educated guess using the share of Tananarive in total provincial expenditure and revenue in 1951 . We extrapolate the revenue and expenditure of Malagasy provinces between 1967 and 1970 by assuming that the share of provinces in total revenue and expenditure was the same as in 1966. We extrapolate the revenue and expenditure of Malian provinces between 1960 and 1965 by assuming that the share of provinces in total revenue was the same as in 1966.

For Algerian départements between 1859 and 1889, our source gives us only aggregate expenditure and revenue. We infer the fiscal structure and sectoral allocation of expenditure using the distribution of 1892.

In the budget accounts of Malagasy provinces between 1947 and 1951, some items of revenue are missing (indirect taxes, revenue of industrial operations and administrative services). We infer them using their shares in total revenue in 1952 (1956 for the province of Tananarive).

Post-independence budget accounts. In Tunisia, posts and telegraphs expenditure is missing in the Franc Zone reports. We use the figures in Tunisia's statistical yearbook to fill in the gaps (see "list of sources" below). From 1958 to 1960, we extrapolate the expenditure of posts and telegraphs assuming that their share in total expenditure was the same than in 1961. 


\section{PERSONNEL DATA}

Provisional budget accounts are usually more detailed than definitive accounts, which allow us to collect some personnel data, such as total number of employees and total personal expenditure per sector. Because counting the total number of employees represents an important collection effort, we limited ourselves to 5 dates as close as possible to 1913, 1925, 1937, 1949, 1955, and $1960 .^{18}$ In each sector, we computed the average wage by dividing total personnel expenditure by the number of employees. We also tried to collect 5 specific wages in a systematic way: the governor's wage, wages of the highest and lowest paid nurse, and wages of the highest and lowest paid teacher.

Provisional budget accounts are very detailed and personnel expenditure can in the majority of cases be matched to an exact number of workers, so that the average wage can be computed. However, some items of personnel expenditure are not attached to a precise number of employees. In that case, we infer the corresponding number of employees by dividing the monetary amount by the average wage of the sector, or, when we can infer that these are low-paying jobs such as servants or manual workers, by the average of the lowest wages in the education and health sectors. Figure 5 and 6 display for each region the number of government employees enumerated in the budget accounts and the number of government employees according to our computations. The discrepancy between the two series is never very important.

Personnel data was collected for central budgets only (federal and colonial in the case of federations), which means that our personnel figure do not include the workers paid for public works on auxiliary budgets, nor the employees paid on the budget accounts of firstlevel administrative divisions. This is particularly problematic in Indochina and in Madagascar. In Indochina, the number of employees of the federal and colonial governments decreased after the decentralization reform of 1931 which gave more spending responsibilities to provinces. The drop in the number of government employees per 1,000 inhabitants from more than 1.7 to less than 1.4 between 1925 and 1937 is therefore misleading (figure 5). In Madagascar, the decentralization reform of 1946 considerably increased the share of provinces in total public expenditure, explaining the fall in the number of government employees between 1938 and 1955 (figure 6).

\footnotetext{
${ }^{18}$ Only dates before World War II for Indochina.
} 
In West and Central Africa, the number of government employees also falls between 1955 and 1960 (figure 6 again), after the colonial territories had been granted more autonomy by the loi cadre of 1956 and the federation had been dismantled in 1959. The magnitude of the decrease cannot be only explained by the departure of French civil servants. We do not know whether it corresponds to an actual drop in the number of public employees or to some decentralization, like in the case of Madagascar, in a context of rapid administrative transformation.

Figure 5: Estimated vs. enumerated number of government employees in North Africa and Indochina
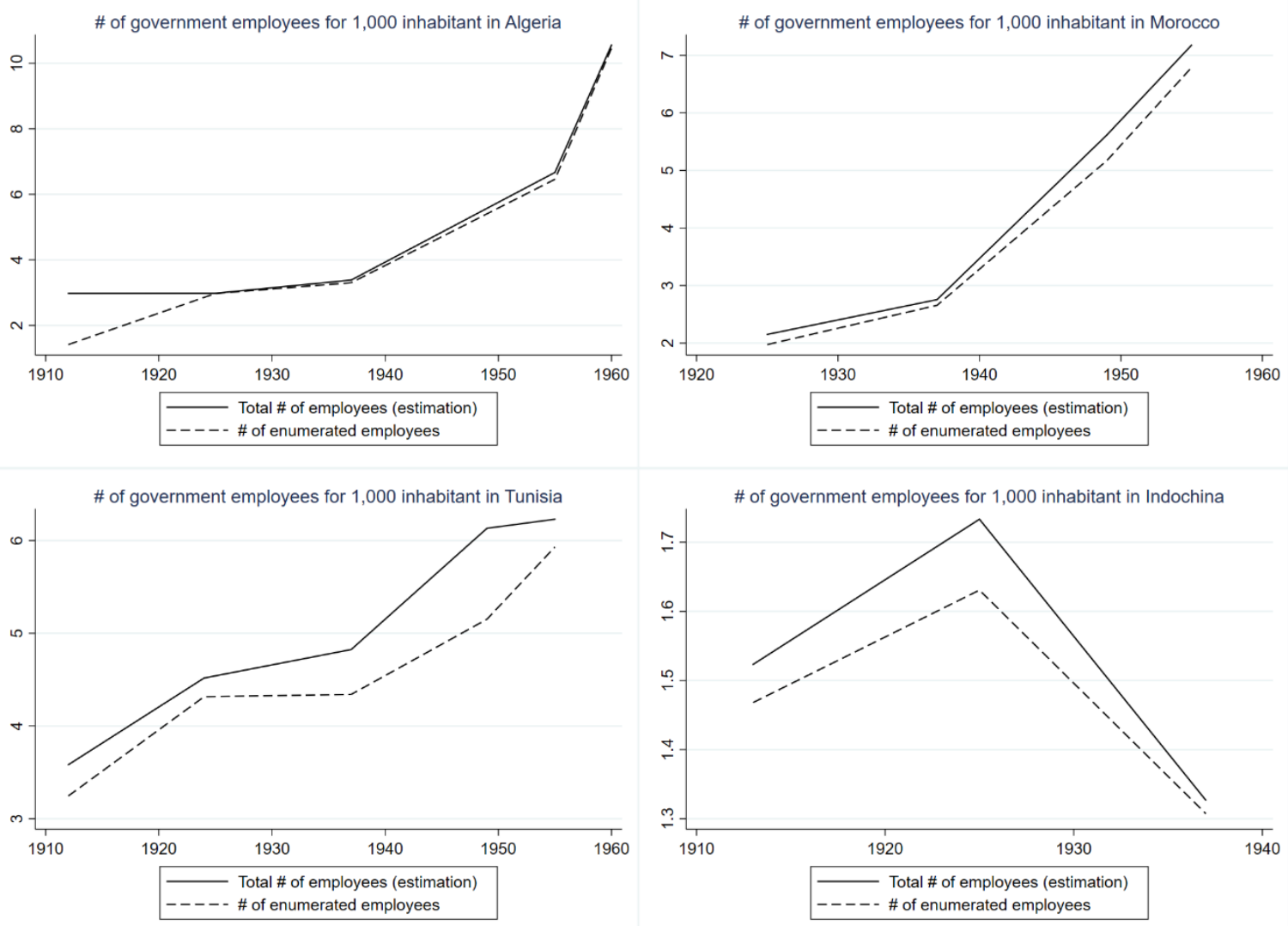
Figure 6: Estimated vs. enumerated number of government employees in Sub-Saharan Africa
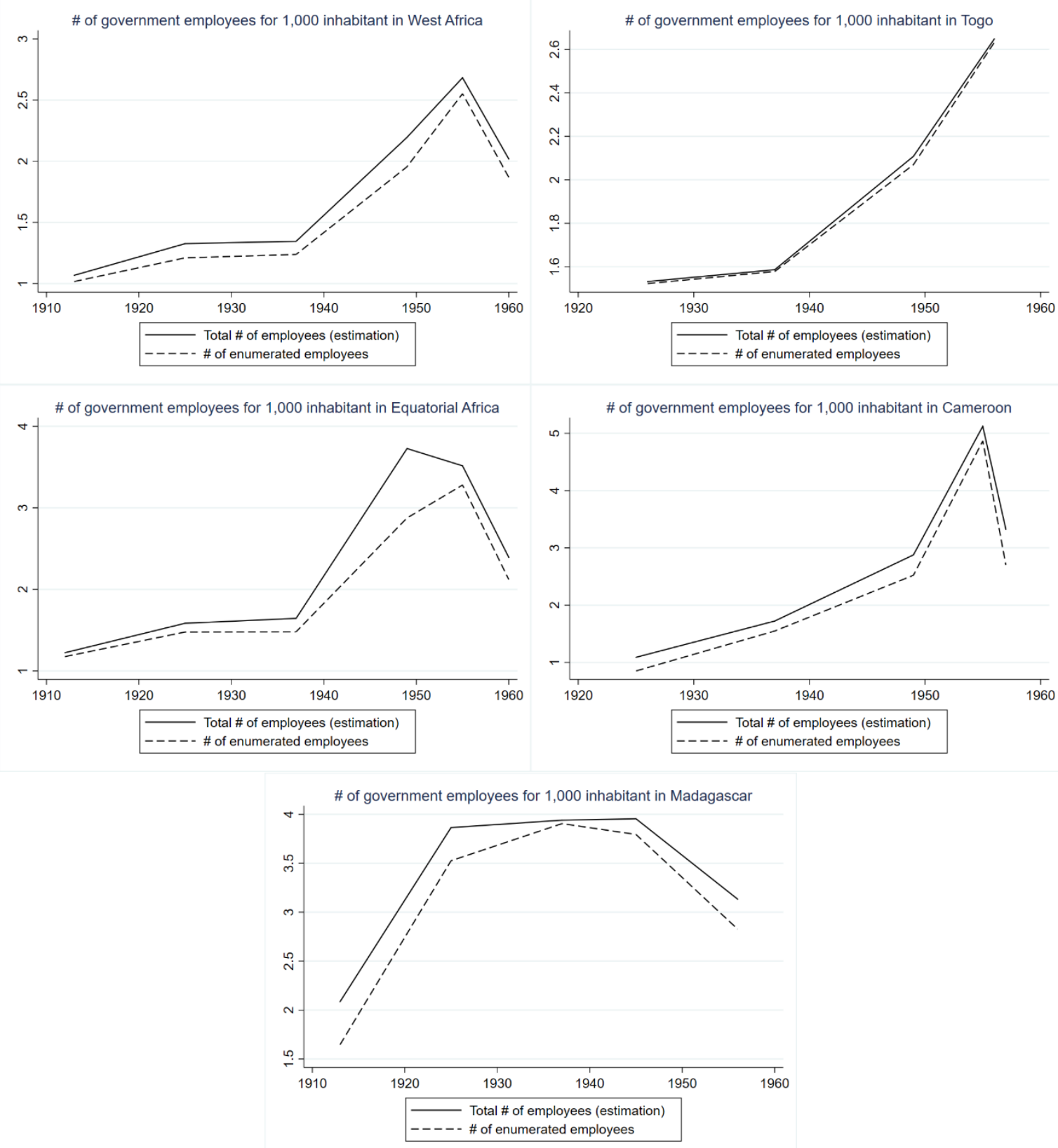

Aggregation and year substitutions. For Indochina, West and Equatorial Africa, figures are aggregated at the level of the federation. As with monetary expenditure, when we could not find provisional budget accounts for a particular colony in a given year, we used the accounts of a close enough year. ${ }^{19}$ We could not find the budget account of French Soudan

${ }^{19}$ In AOF, affected years and budget accounts are: budget général (1936 instead of 1937), Cote d’Ivoire (1926 instead of 1925), Dahomey (1957 instead of 1960), Guinée (1950 insteadof 1949), Mauritania (1958 instead of 1960), and Niger (1958 instead of 1960). .In AEF: Gabon (1958 instead of 1960), Oubangui-Chari (1959 instead of 1960), and Tchad (1958 instead of 1960). In Indochina: budget général (1914 instead of 1913), Cochinchina (1915 instead of 1915 and 1924 instead of 1925). 
(present-day Mali) in 1925, 1949 and 1960. In these years in AOF, average wages per sector do not take French Soudan/Mali into account. In 1925 and 1949, total employment in AOF is computed using the share of Soudan in the total employment of the federation in 1937 and 1955. In 1960, aggregate figures for AOF are computed without Soudan/Mali, and without Guinea - in 1958, the federation of AOF was dissolved, and Guinea gained independence. We could not find the budget account of Chad in 1949: average wages per sector in AEF do not take Chad into account for this year, and total employment in AEF is computed using the share of Chad in the total employment of the federation in 1955.

Comparison with Metropolitan France. For the years 1925 and 1955, we compute public employment and average wage per sector for the central government of Metropolitan France. Public employment by category in 1922 and 1956 is given in INSEE (1966, p. 114). The wage bill by sector in 1923 and 1956 is given in André and Delorme (1983, pp. 734 and 739). The wage bill of posts and telegraphs in 1925 and 1955 is given in the annual reports of posts and telegraphs. We use the growth rate of total population to extrapolate the total number of employees and the wage bill for the relevant years (1925 and 1955).

\section{POPULATION, PRICES, AND GDP}

\section{POPULATION}

To produce comparable estimates of expenditure and revenue per capita, we gathered data on total population. We also gathered data on European and other ethnic minority populations (Jews in North Africa, Chinese in Indochina, Chinese and Indians in Madagascar). For a handful of years (1925, 1945, and 1955), we estimated the population share of 15-64-year-olds (in order to express public wages in units of GDP per worker). For the years 1850, 1925 and 1855, we also estimated urbanization rates. The "Population" section of the "List of sources" below gives a more detailed list of all references used and where to find them.

\section{Algeria}

In Algeria, population in 1850 comes from CICRED (1974a). Population figures from the censuses of 1911, 1921, 1926, 1931, 1936, 1948 and 1954 come from the 1955 statistical yearbook of Algeria (Algeria, Sous-direction des statistiques, 1955). Population in 1960 comes from the 1960 UN demographic yearbook (United Nations, 1960). Population in 1966 
comes from CICRED (1974a). Population from 1977 comes from The World Bank (2017). ${ }^{20}$ European population is defined as non-Muslim population, comprising French citizens (including Algerian Jews who were granted French citizenship by the 1870 Crémieux decree) and other Europeans. Population figures for non-Muslims are more detailed and come from the Algerian statistical yearbooks of 1933, 1948-1949 and 1955 (Algeria, Sous-direction des statistiques, 1933, 1948-49, 1955) who present retrospective figures as well as contemporary ones. Figures for 1958-1960 come from the 1961 and 1962 French statistical yearbooks (INSEE, 1961 \& 1962). 1960 non-Muslim population comes from CICRED (1974a). Population figures between two dates are estimated by exponential interpolation, except for 1) Muslim population before 1850 , where we assume a growth rate of $0.5 \%$ per year, the rate given by CICRED (1974a) between 1850 and 1866; 2) Muslim population between 1866 and 1911, where our figures reflect a decrease in population between 1866 and 1872 due to epidemics and the Kabyle revolt of $1871-1872^{21}$; 3) Muslim population between 1954 and 1960, where we take into accounts the temporary departure of Algerian refugees to Tunisia and Morocco (UNHCR 2000); 4) non-Muslim population between 1960 and 1966, where our figures reflect the departure of 800,000 French settlers in 1962.

The share of 15-64-year-olds in the non-European population comes from CICRED (1974a). The share in 1955 is assumed to be equal to the share of 1954 from CICRED (1974a). The share in 1925 is extrapolated using the share in 1936 and the trend between 1936 and 1948. The share of 15-59-year-olds in the European population is given in the statistical yearbooks of Algeria, and we assume that the share of 60-64-year-olds is the same as in Metropolitan France.

Urban population figures come from Eggiman (1999) for 1850, from the population census of 1926 for 1925, and from the population census of 1954 for 1955 (46 communes).

\section{Morocco}

During the colonial period starting in 1912, Morocco was divided between a French Protectorate and a Spanish Protectorate in the North representing about a tenth of total population. ${ }^{22}$ Morocco gained its independence from France in 1956 and Moroccan control over (part of) the Spanish zone was restored in 1958. Our population estimates comprise only

\footnotetext{
${ }^{20}$ To stay consistent with the colonial figures, which never comprise military population, we subtract from the WDI figures estimates of military population (representing around $1 \%$ of total population).

${ }^{21}$ If we assume again a population growth rate of $0.5 \%$ a year between 1872 and the first reliable population census of 1911, we find that population decreased by 12\% between 1866 and 1872 .

${ }^{22}$ The Spanish were also granted a Protectorate in the South, but its population was negligible.
} 
the southern (French) zone until 1957, and both zones from 1958 onwards. Population in 1936 comes from CICRED (1974b). Earlier population figures are extrapolated backwards using the population growth rates of Frankema and Jerven (2014). Population in 1952 comes from Morocco (1960). Population in 1960 and 1971 comes from CICRED (1974b). Population after 1982 comes from The World Bank (2017). European population is French population (unlike in Algeria, Moroccan Jews were not granted French citizenship), given by the Moroccan statistical yearbook in 1921, 1926, 1931, 1936, 1947, and 1952 (Morocco, various dates). Jewish population comes from CICRED (1974b), Morocco (1960) and Moroccan statistical Yearbooks (Morocco, various dates). Population figures between two dates are estimated by exponential interpolation.

The shares of 15-64-year-olds in the European and non-European population are assumed to be the same as in Tunisia.

Urban population figures come from Eggiman (1999) for 1850 and for 1925 (interpolation of 1920 and 1930 figures), and from Eggiman (1999) and The World Bank (2017) for 1955 (average of Eggiman’s figure for 1950 and World Bank figure for 1960).

\section{Tunisia}

In Tunisia, population in 1911 comes from the 1947 statistical yearbook (Tunisia, Institut national de la statistique, 1947). ${ }^{23}$ Earlier population figures are extrapolated backwards using a yearly growth rate of $0.7 \%$, fitting the estimates given by CICRED (1974c). Population figures in 1921, 1926, 1931, 1936, 1946, 1956, 1966, and 1971-1973 come from CICRED (1974c). Population after 1971 comes from The World Bank (2017). European population is mostly French, Italian, and Maltese (unlike in Algeria, Tunisian Jews were not granted French citizenship). It is given by the 1947 Tunisian statistical yearbook for $1880,1886,1891,1896,1906,1911,1921,1926,1931,1936$, and 1946. It is given by the 1957/58 statistical yearbook for 1956. It is given by CICRED (1974c) for 1961 and 1966. Jewish population comes from Tunisian statistical yearbooks. Population figures between two dates are estimated by exponential interpolation.

The share of 15-64 year olds in the Muslim population comes from CICRED (1974c). The share in 1955 is assumed to be equal to the share of 1956 from CICRED (1974a). The share in 1925 is extrapolated from the share in 1946 using the evolution of the share of 15-64year-olds in the Muslim population of Algeria between 1925 and 1946. The share of 15-59-

${ }^{23}$ Because colonial population figures tend to underestimate population, we multiply the 1911 population figure by the ratio of the CICRED (1974) figure over the 1947 statistical yearbook figure in 1921, a year for which we have both figures. 
year-olds in the European population is given in the statistical yearbooks of Tunisia, and we assume that the share of 60-64-year-olds is the same as in Metropolitan France.

Urban population figures come from Eggiman (1999) for 1850, from the population census of 1921 for 1925, and from the population census of 1956 for 1955 (cities above 10,000 inhabitants).

\section{Indochina}

In Indochina, population figures for Vietnam (Cochinchina, Annam, and Tonkin) come from Bassino (2000) and Banens (2000). For Cambodia and Laos, we use The World Bank (2017) after 1960. Before 1960, population figures are extrapolated backwards using the population growth rate of Vietnam. The figures thus obtained are slightly larger than the ones provided in the statistical yearbooks of French Indochina (French Indochina, Bureau de la statistique générale, various dates). European population and Chinese population are given by the statistical yearbooks of French Indochina. European population is composed mostly of French, but the figures given by statistical yearbooks also include a small minority of Americans and Japanese.

The share of 15-64-year-olds in the non-European population comes from Banens (2000). The share of 15-64-year-olds in the European population comes from the 1921 population census and the 1948 statistical yearbook of Indochina and is extrapolated to 1925, 1945 and 1955.

Urban population figures come from Chandler (1987) for 1850, for 1925 from an interpolation of the population censuses of 1921 and 1931, and for 1955 from a backward interpolation of the World Development Indicators figure of 1960.

\section{West and Central Africa}

Population in Afrique Occidentale Française, Afrique Equatoriale Française, Togo and Cameroon comes from Frankema and Jerven (2014) between 1850 and 1960 and from The World Bank (2017) after 1960. The population given by Frankema and Jerven (2014) for Mali and Niger at independence in 1960 is lower than the population given by the World Bank. We therefore opted for higher population growth rates from 1948 to 1960 in order to make the two series consistent. Frankema and Jerven (2014) give figures for African countries in their post-independence borders, but French Cameroon was smaller during the colonial period because it was reunited with former British Cameroon in 1961. We adjust colonial population figures by removing 15\% of French Cameroon's population, which corresponds to the ratio obtained by combining French and British colonial estimations (France, Ministère de 
la France d'Outre-mer, 1959; Great Britain, Colonial Office, various dates). European population comes from the statistical yearbooks of AOF and AEF, and, for Togo and Cameroon, from France, Ministère de la France d'Outre-mer (1959).

The share of 15-64-year-olds in the European population in 1925 and 1955 is obtained by averaging the Algerian and Tunisian shares. The share of 15-64-year-olds in the nonEuropean population in 1925 is supposed to be equal to the Algerian share (Muslim population). The share of 15-60-year-olds in the non-European population in 1955 is a weighted average (by total population) of the country-level estimates reported by Tabutin \& Schoumaker (2004) for the year 1950 (Table A.11). The relative share of 60-64-year-olds is assumed to be the same as in 1954 Algeria (Muslim population).

Urban population figures come from Eggiman (1999) for 1850, from an exponential interpolation of Africapolis data for 1920 and 1930 for 1925 AOF and Togo ${ }^{24}$, from Eggiman again for 1925 AEF and Cameroon (1930 figures extrapolated backward), and The World Bank (2017) for 1955 (1960 figures).

\section{Madagascar}

In Madagascar, population comes from the statistical yearbooks of Madagascar and from The World Bank (2017) after 1970. Population between two dates is estimated by exponential interpolation. Before 1906, we extrapolate backwards using the population growth rate of $0.3 \%$ given by Frankema and Jerven (2014). European population and Asian population are given in statistical yearbooks and France, Ministère de la France d'Outre-mer (1959).

The share of 15-64-year-olds in the European population in 1925 and 1955 is obtained by averaging the Algerian and Tunisian shares. The share of 15-64-year-olds in the nonEuropean population in 1925 is supposed to be equal to the Algerian share (Muslim population). The share of 15-60-year-olds in the non-European population in 1955 is the estimate reported by Tabutin \& Schoumaker (2004) for the year 1950. The relative share of 60-64-year-olds is assumed to be the same as in 1954 Algeria (Muslim population).

Urban population figures come from Eggiman (1999) for 1850 and for 1925 (interpolation of 1920 and 1930 figures), and from Eggiman and The World Bank (2017) for 1955 (average of Eggiman’s figure for 1950 and World Bank figure for 1960).

${ }^{24}$ We thank Eric Denis (UMR Géographie-Cités) and the Africapolis project for sharing their unpublished data on West African cities for the years before 1950. 


\section{Metropolitan France}

In Metropolitan France, total population comes from Vallin and Meslé (2001) and population censuses. The share of 15-64-year-olds in total population comes from INSEE (1966).

\section{PRICES}

In Northern and Sub-Saharan Africa, monetary amounts collected in various budget sources are usually given in French francs. Just after World War II, a new currency was introduced in the colonies of Sub-Saharan Africa, the CFA franc ("franc des colonies françaises d'Afrique”), worth 1.7 Metropolitan francs. It was worth 2 Metropolitan francs from 1948 onwards. Our own series show that the official exchange rate roughly compensated for the inflation differential between Metropolitan France and French West Africa during World War II, but that the CFA franc was likely overvalued in French Equatorial Africa, Cameroon and Madagascar. In the French Indochinese Union, the official currency from 1884 onwards was the piastre, a silver currency similar in weight to the Mexican peso and the Trade dollar. The piastre remained on a silver standard until 1920 and was then pegged to the franc at a variable rate. In 1930, the exchange rate was fixed at 1 piastre for 10 francs. After the Second World War and the Japanese occupation, the exchange rate was fixed at 1 piastre for 17 francs, but it was largely overvalued, as evidenced by a black market exchange rate of less than 10 francs. Our own series show that inflation was far greater in Indochina than in Metropolitan France during the independence war years.

When considering public finance series, how should we deflate and adjust for purchasing power parity? The answer partly depends on the type of questions asked, and practical solutions are greatly constrained by the availability of price and wage data for the period considered. Under the angle of revenue, it makes sense to use something akin to a GDP deflator, especially when considering the share of public revenue in GDP as an indicator of fiscal capacity. Because of the limited availability of price data, we deflate and adjust for purchasing power using a basket of consumer goods. Under the angle of expenditure, if we want to compare across time and across space the quantity of public goods and services provided, a specific public spending deflator would be more appropriate, especially for taking into account differences in public sector wages. Building such a deflator would require detailed information on the skill composition of government sector jobs and corresponding salary scales. The lack of such detailed data leads us to deflate public expenditure with the 
same Consumer Price Index (CPI) deflator we use for public revenue. This has the additional advantage of simplicity: because expenditure and revenue are expressed in the same unit of account, deficits can be computed by subtracting net expenditure from net revenue. However, in our cross country comparisons as well as in our time series, a large share of the variation in public expenditure is accounted for by differences in public sector wages, something we evidence by also providing series on the number of government employees per capita and on average wages. In fact, every possible public expenditure deflator taking into account public sector wages will be a weighted average of two extreme scenarios: in the first one (CPI based adjustment), we assume that differences in real wages are a perfect indicator of differences in labour productivity, in the second one (number of employees per head), we give the same value to each government job, regardless of differences in skills and productivity.

In the end, we adjust all our monetary aggregates using the following method: we use local CPIs to express monetary amounts in 1937 local currency (francs and piastres), and then use the relative cost of a basket of goods to adjust for purchasing power parity in 1937. Local CPIs were found in various statistical abstracts (see the "Prices" section of the "List of sources” below). The earliest ones start in 1913, and most of them start in 1938. Before this date, we convert monetary amounts in French francs and deflate using a French GDP deflator obtained by chaining the INSEE deflator after 1949, Villa (1997) between 1900 and 1948, and Toutain (1987) before 1900. The conversion matters only for Indochina, as in all other colonies before World War II, the official currency was the French franc. In Sub-Saharan Africa (AOF, AEF, Togo, Cameroun and Madagascar), we could not find information on price inflation in the second half of the 1950s. We infer price inflation between 1953 and 1960 by taking the difference between the nominal GDP growth and real GDP growth (see section on GDP below). ${ }^{25}$ After World War II, we rely on local CPIs from The World Bank (2017).

Figure 7 compares the evolution of prices in France and its colonial empire between 1939 and 1960. The first panel displays the evolution of local consumer price indices in France and the North African territories of Algeria, Morocco, and Tunisia. During WW2, inflation was higher in North Africa than in Metropolitan France, yet in Algeria prices had converged to the level of Metropolitan France in 1954, and were slightly lower afterwards. In Tunisia, the CPI converged in 1960 only, that is after independence, and in Morocco, it had

\footnotetext{
${ }^{25}$ Nominal GDP in 1953 is from France, Direction des Affaires économiques et du Plan du ministère de la France d'outre-mer (1955), nominal GDP in 1960 is from The World Bank (2017). Real GDP growth in the 1950s is from the Maddison Project. In Togo, we did not find nominal GDP figures nor prices before 1960. Before this date, inflation is assumed to be the same as in AOF.
} 
not converged in 1960. 1937-1946 inflation was lower in France’s Sub-Saharan possessions (panel 2). Madagascar was an exception, as its CPI was only slightly lower than that of France at the end of the war. The introduction of the CFA franc in December 1945, worth 1.7 Metropolitan francs, and its revaluation in 1948 to 2 Metropolitan francs, compensated exactly for the accumulated inflation differential in 1948, for all Sub-Saharan territories except Madagascar. Between 1948 and 1960, prices caught up with Metropolitan levels, especially in AEF, and it seems that the CFA franc turned strongly overvalued. In Indochina (panel 3), the divergence between the 2 price indices is very wide, especially after World War 2. Despite this inflation differential, the exchange rate was fixed a 1 Indochinese piastre for 10 francs from 1930 to 1945, and was increased instead of decreased in 1945, at 1 piastre for 17 francs. The discrepancy between the official exchange rate and the black market rate gave rise to the trafficking documented in Despuech (1953). The rate of 1 for 10 was restored in 1953.

Figure 7: Inflation differential between France and its colonies
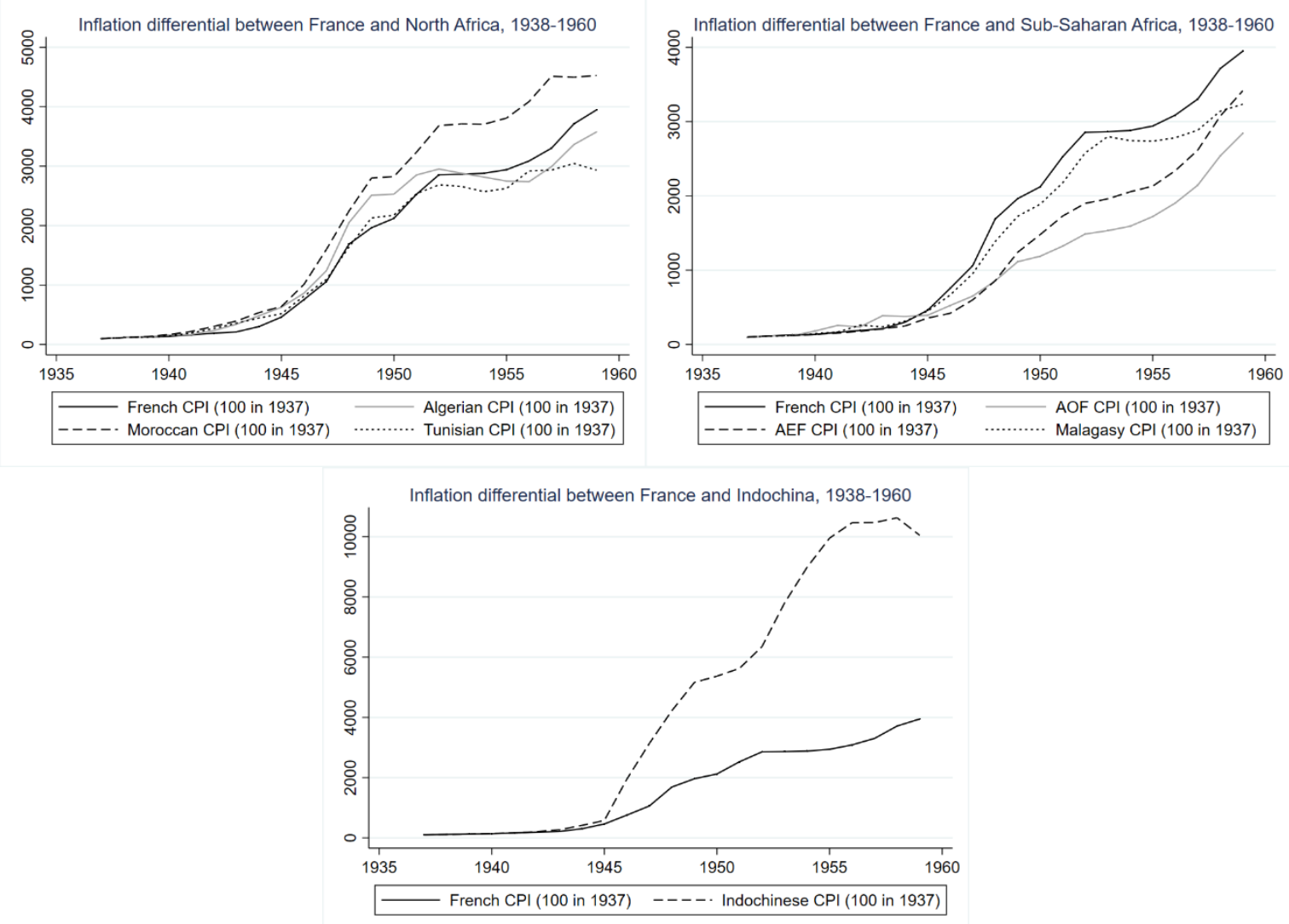
Once we have expressed all monetary amounts in 1937 local currency using the local CPIs, we adjust for purchasing power parity (PPP) in 1937 using the relative cost of a basket of good. The products and weights used (displayed in table 4) closely follow those used by the French statistical office in the 1950s (INSEE, 1951). ${ }^{26}$ They match the consumption pattern of a European or a member of the colonized elite. Table 5 presents the price of our basket of goods relative to Algeria, using the official conversion rate for the piastre. ${ }^{27}$ In Sub-Saharan Africa, where the Metropolitan franc was used in 1937, we actually would not be far off to assume that one franc had the same purchasing power everywhere. In Indochina, the purchasing power of the franc implied by the official exchange rate of 10 francs for a piastre is far greater than in the rest of the Empire.

Table 4: products and weights used to adjust for PPP in 1938

\begin{tabular}{lc} 
Product & Weight \\
\hline Starch (flour, rice) & 11 \\
Meat (chicken, beef) & 18.4 \\
Eggs & 14.5 \\
Cooking oil & 3.8 \\
Grocery (sugar, salt) & 12.1 \\
Petroleum & 3.4 \\
Electricity & 0.7 \\
Soap & 8.2 \\
Shoes & 12.4 \\
Haircut & 15.5 \\
\hline Total & 100.0 \\
\hline
\end{tabular}

Table 5: Price of the consumer basket relative to Algeria in the French Empire

$\begin{array}{ll}\text { Algeria } & 1.00 \\ \text { Morocco } & 0.88 \\ \text { Tunisia } & 0.95 \\ \text { Indochina } & 0.62 \\ \text { West Africa } & 0.92 \\ \text { Equatorial Africa } & 0.93 \\ \text { Cameroon } & 0.83 \\ \text { Madagascar } & 0.81\end{array}$
quantities.

${ }^{26}$ Since we always consider relative prices of baskets of goods, there is no need to specify units and

${ }^{27}$ We assume that in 1937, the price level in Algeria was very close to the price level in Metropolitan France. 


\section{GROSS DOMESTIC PRODUCT}

Though evidence on historical GDP in Africa is scarce, some measure of GDP is needed to put fiscal figures in economic context and express public revenue as a share of GDP, a standard and useful measure of fiscal capacity (Besley and Persson, 2014). To obtain yearly estimates of real GDP per capita, we combine two main sources: contemporary national accounting exercises give us nominal GDP from the 1950s onwards, while historians' estimations of GDP growth in volume give us real GDP growth before 1950. These sources, laid out in details in the "Gross domestic product" section of the "List of sources" below, are combined with our price deflator, PPP adjustor, and population series to obtain series of real GDP per capita in 1937 francs. The deflator and PPP adjustor used to convert nominal GDP in 1937 PPP francs are the same as those used to deflate our public finance data, making the computation of GDP shares straightforward.

In Algeria, we take yearly nominal GDP between 1950 and 1957 from Algeria, Service de statistique générale (1958, p. 54), in 1958 and 1959 from Amin (1966, p. 194195), and from 1960 onwards from The World Bank (2017).To obtain real GDP figures before 1950, we use real GDP growth estimated by Amin (1966, p.101) between 1880 and 1950 and by Maddison (2003) between 1820 and 1880 .

In Morocco, we use the nominal GDP series of The World Bank (2017) from 1960 onwards. We use the growth of real GDP of Amin (1966) between 1920 and 1960, and of Maddison (2003) between 1820 and 1920. We do not use the nominal GDP series of Amin directly because the figure he gives for 1960 is $25 \%$ higher than the one given by The World Bank (2017).

In Tunisia, we take nominal GDP in 1957 and 1960 from Amin (1966, p. 297), and nominal GDP after 1965 from The World Bank (2017). Real GDP in other years is computed using the real growth rates of Zarka (1964, p. 214) between 1950 and 1960, and the growth rate of Maddison between 1960 and 1965. Before 1950, we use the growth rate of real GDP given by Amin (1966, p. 35 \& p. 101) between 1920 and 1950, and Maddison (2003) between 1820 and 1920.

In Indochina, we take the nominal GDP series of Bassino (2000) for Vietnam (Cochinchina, Annam, and Tonkin) between 1820 and 1970, that we deflate using our CPI. The real GDP per capita of Cambodia and Laos is assumed to be equal to the real GDP per capita of Annam. 
In Sub-Saharan Africa (A.O.F, AEF, Togo, Cameroon, and Madagascar), we rely on the nominal GDP series of The World Bank (2017) after 1960. In 1953, we rely on national accounts established by the French Overseas Ministry for AOF, A.E.F, Cameroun, and Madagascar (France, Direction des Affaires économiques et du Plan du ministère de la France d'outre-mer, 1955). Growth rate of real GDP per capita between 1953 and 1960 are taken from the Maddison Project. Because we do not have good data on inflation in the 1950s, the difference between the growth rate of nominal GDP per capita and the growth rate of nominal GDP per capita gives us a measure of price inflation that we use to deflate our public finance series. ${ }^{28}$ Real GDP per capita before 1953 is obtained using the real GDP growth rates given in Maddison (2003).

Finally, in Metropolitan France, we take the GDP at market prices from INSEE national accounts between 1949 and 2010, deflated using our GDP deflator. Between 1900 and 1949, we extrapolate backwards using the annual growth rates of market GDP estimated by Villa (1997), taking into account the gradual increase in the share of non-market GDP using estimates from Vincent (1972, p. 334) for 1913, 1929, and 1938. Between 1820 and 1900, we extrapolate backwards using annual growth rates estimated by Toutain (1987).

Extrapolation of GDP fluctuation from import and export series. Most of our sources estimate real GDP growth before 1950 only between a couple of key years. ${ }^{29}$ We extrapolate deviations around an exponential trade using the fluctuations of imports and exports, for which we have yearly observations from Marseille (1984). We proceed in the following way: in the period 1950-1973 (when we have yearly observations of GDP, exports and imports), we estimate the following relationship for each country (or group of countries in the case of federations) ${ }^{30}$ :

$$
\ln \left(G D P_{t}\right)=\beta+a \ln \left(\text { exports }_{t}\right)+\ln \left(\text { imports }_{t}\right)+c \times t+u_{t}
$$

Where GDP, exports and imports are deflated in 1937 francs using the same deflator, and expressed in per capita terms. By the Frisch-Waugh theorem, this is equivalent to first estimating the deviations of GDP, exports and imports around an exponential trend:

\footnotetext{
${ }^{28}$ Because we did not find estimates of nominal GDP in the 1950s in Togo, inflation in the 1950s is assumed to be the same as in AOF Nominal GDP in 1960 is deflated in 1937 PPP F using the prices of AOF, and real GDP is then computed using the real growth rates of Maddison (2003).

${ }^{29}$ Maddison (2003) gives an estimate of real GDP per capita for "Other countries of Black Africa" in 1820, 1870, and 1913. Amin (1966) gives estimates of real GDP in 1880, 1910, 1920, 1930, 1955 and 1960 in the Maghreb.

${ }^{30}$ We stop in 1973 to avoid the period following the oil shock, which might be very specific. The years on which this equation is estimated are 1950-1973 for Algeria, Tunisia and Morocco; 1947 and 1953-1973 for AOF, AEF, Cameroon and Madagascar; 1948 and 1950-1973 for Togo. We do not need to extrapolate GDP from imports and exports in Indochina as complete series are already given in Bassino (2000).
} 


$$
\begin{gathered}
\ln \left(G D P_{t}\right)=d_{G D P}+c_{G D P} \times t+e_{G D P, t} \\
\ln \left(\text { exports }_{t}\right)=\beta_{\text {exports }}+c_{\text {exports }} \times t+e_{\text {exports }, t} \\
\ln \left(\text { imports }_{t}\right)=\beta_{\text {imports }}+c_{\text {imports }} \times t+e_{\text {imports }, t}
\end{gathered}
$$

Then estimating $a$ and $b$ from the residuals:

$$
\hat{e}_{G D P, t}=a \hat{e}_{\text {exports }, t}+b \hat{e}_{\text {imports }, t}+v_{t}
$$

We then use parameters $a$ and $b$ estimated for each country or group of countries to extrapolate the variations of GDP around an exponential trend from yearly series on exports and imports. For a given country, we observe GDP in year $t$ and year $t+h$. We start by detrending the series of imports and exports between $t$ and $t+h$ by estimating

$$
\begin{aligned}
& \ln \left(\text { export }_{t+i}\right)=\gamma_{\text {exports }}+k_{\text {exports }} \times i+e_{\text {exports }, t+i} \\
& \ln \left(\text { imports }_{t+i}\right)=\gamma_{\text {imports }}+k_{\text {imports }} \times i+e_{\text {imports }, t+i}
\end{aligned}
$$

For $i$ between 0 and $h$. We then compute the deviation of GDP from an exponential trend from the residuals: $\hat{e}_{G D P, t+i}=\hat{a} \hat{e}_{\text {exports }, t+i}+\hat{b} \hat{e}_{\text {imports }, t+i}$. Then we can write GDP at time $t+i$ as $\ln \left(G D P_{t+i}\right)=\gamma_{G D P}+k_{G D P} \times i+\hat{e}_{G D P, t+i}$. Because we know GDP at the two endpoints $t$ and $t+h$, we can compute parameters $\gamma_{G D P}$ and $k_{G D P}$ and compute GDP at every intermediate point. $^{31}$

Our GDP estimations can be seen in figure 8, displaying the evolution of GDP per capita in 1937 francs in the 9 regions of our database.

Figure 8: Estimation of GDP per head in the nine regions of the French Empire
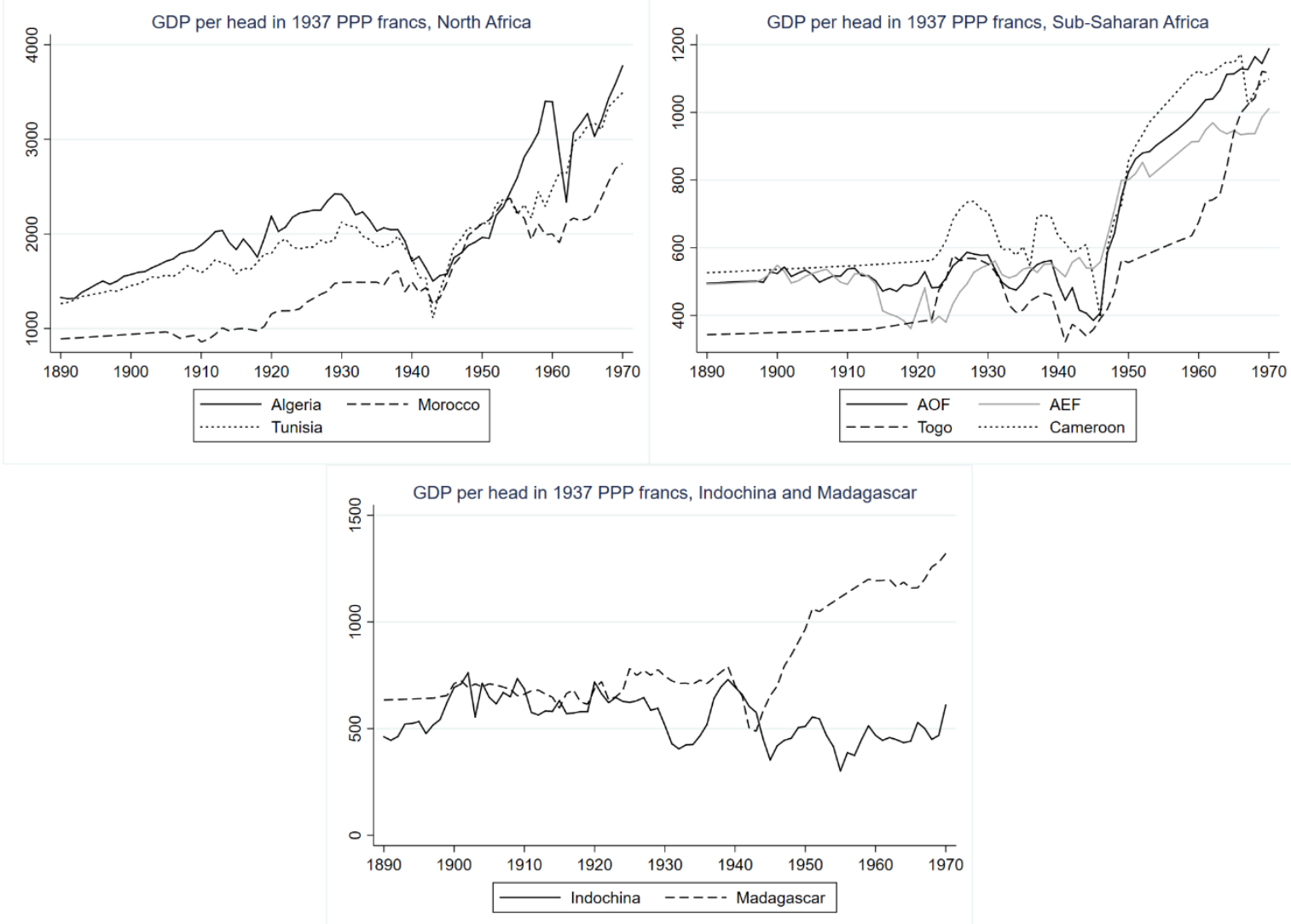


\section{DEVELOPMENT OUTCOMES}

Development outcomes (kWh produced, road and railway meters, primary enrolment and number of medical staff) come from various statistical yearbooks - see the list of sources below.

\section{VARIABLE DICTIONARY}

\section{PUBLIC FINANCE DATABASE}

Variables in the public finance database are given per head in 1937 PPP Francs. To recover nominal amounts as they appear in the budget accounts, one needs to divide by the price deflator (deflator) and the purchasing power parity adjustor (PPP_adjustor) and multiply by population (pop).

\section{Region}

One of nine colonies, protectorates, mandates, or federations or colonies: Algeria, Morocco, Tunisia, Indochina, West Africa, Togo, Equatorial Africa, Cameroon, and Madagascar.

\section{Year}

\section{Net public expenditure (NPE)}

Net public expenditure is total public expenditure net of transfers to reserve funds, external loans, subsidies and debt service. It is a consolidated aggregate, meaning that it is net of the various financial transfers (loans, subsidies, etc.) between different public budgets accounts within the same region (federal, colonial, and auxiliary budgets, and budgets of first-level administrative divisions). However, NPE includes subsidies and loans to firms and institutions located within the region, as well as subsidies and loans to second-level administrative divisions (municipalities). NPE also includes the civilian expenditure recorded in the budget accounts of the French Ministry of Colonies and Ministry of War. It does not include social security transfers. After independence, when Franc Zone reports are used as sources, NPE is computed as total expenditure minus debt service as recorded in Franc Zone reports, minus all external loans and subsidies received by the country recorded in the Franc Zone report (except when we know these emanate from a private source or a non-OECD country), 
plus net OECD ODA (loans and grants) received by the country (see "Budget accounts considered and sources used” above).

\section{Administration expenditure (exp_administration)}

Administration expenditure comprises personnel and material expenses destined to general and territorial administration. It comprises financial transfers to autochthonous political authorities, such as the king of Laos, or the sultan of Morocco.

\section{Security expenditure (exp_security)}

Security expenditure comprises personnel and material expenses of the police and prisons.

\section{Justice expenditure (exp_justice)}

Justice expenditure comprises personnel and material expenses destined to Autochthonous and European justice.

\section{Financial services expenditure (exp_finserv)}

Financial services expenditure comprises personnel and material expenses destined to tax collection, the management of the public debt, and the management of government monopolies (on salt, opium, etc.)

\section{Education expenditure (exp_education)}

Education expenditure comprises personnel and material expenses destined to public education, subsidies to private schools, and scholarships. School construction expenses are classified as infrastructure expenditure. In all French colonies, schools were segregated into a European system and a system for the autochthonous population. In Algeria between 1904 and 1948, and in Morocco between 1926 and 1930, it is possible to identify education expenditure for Autochthons (exp_education_au) and for Europeans (exp_education_eu). The two subcategories do not necessarily sum to total education expenditure because some expenses were common to both education systems. Education expenditure for Autochthons and Europeans are expressed per head of the relevant population: expenditure for Europeans are divided by European population (pop_eu) and expenditure for Autochthons are divided by autochthonous population (pop minus pop_eu). 


\section{Religion expenditure (exp_religion)}

Religion expenditure is positive only in Algeria, where the government took charge of the personnel and material expenses of the 4 monotheist religions (Islam, Judaism, Protestantism, and Catholicism). The law of separation of church and state was only partially applied in Algeria, where the government continued subsidising religions after 1907, and notably continued paying the wages of the Muslim religious personnel in an effort to control Islam and avoid political turmoil (Saaidia, 2016).

\section{Health expenditure (exp_health)}

Health expenditure comprises the personnel and material expenses destined to health, sanitation, labor inspection, and welfare. It does not include social security transfers. Hospital and health centers construction expenses are classified as infrastructure expenditure.

\section{Infrastructure expenditure (exp_infrast)}

Infrastructure expenditure comprises expenses for public works, both the construction of new infrastructure and buildings and the maintenance of existing ones. The construction of new railway lines or telegraphic lines falls in this category, but subsidies to railway companies are classified as production support expenditure, as well as the operating expenses of posts and telecommunications. Infrastructure expenditure also comprises the subsidies to second-level administrative divisions destined to the maintenance of local roads (in Algeria only).

\section{Production support expenditure (exp_prodsup)}

Production support expenditure comprises subsidies to private and public or semipublic entities whose budgets are not already part of the public expenditure aggregate (like railway companies). It also includes expenses on public services destined to enhance or support production, like posts and telecommunications, power plants, printing department, meteorological department, civil aviation, forestry and mining departments, agricultural research, merchant navy, etc.

\section{Other expenditure (exp_other)}

Other expenditure is equal to the difference between net public expenditure (NPE) and the sum of all previous items of expenditure: administration, security, justice, financial services, education, religion, health, infrastructure, and production support. Expenditure remaining from the previous financial year (Dépenses d'exercices 
antérieurs / d'exercices clos) is allocated between the different items of expenditure in proportion of their weight in total expenditure.

\section{Military expenditure (exp_mili_fr and exp_mili_col)}

Our measure of net public expenditure includes civilian expenditure only. Military expenditure is given separately. The bulk of colonial military expenditure appears in the budget accounts of the French Ministry of the Colonies and Ministry of War and is given by the variable exp_mili_fr. Some items of military expenditure given by the Metropolitan budget accounts are civilian in nature and were added to the relevant categories of net public expenditure (exp_health, exp_infrastructure, and exp_prodsup). On the revenue side, they are considered as subsidies from France. Military expenditure appears directly in colonial budget accounts only in Algeria between 1830 and 1900 and between 1904 and 1937 (budget accounts of Southern Territories only), and in Morocco between 1921 and 1937, and in 1956. It is given by the variable exp_mili_col.

\section{Net public revenue (NPR)}

Net public revenue is public revenue net of transfers from reserve funds, external borrowing, subsidies, interests and reimbursements. It is a consolidated aggregate, meaning that it is net of various financial transfers (loans, subsidies, etc.) between different public budgets accounts within the same region (federal, colonial, and auxiliary budgets, and budgets of first-level administrative divisions). However, NPR includes transfers (subsidies, loans, and reimbursements) from firms and institutions located within the region, as well as transfers from second-level administrative divisions (municipalities). NPR does not include social security transfers.

\section{Tax revenue (taxrevenue)}

Tax revenue is the sum of head taxes, external trade taxes, intermediate taxes, and modern taxes

\section{Head taxes (re_headtax)}

Revenue from the head tax (capitation), in theory a lump-sum tax, in practice a tax levied at the village level by local chiefs and roughly proportional to population. This category also includes cattle taxes (in Tunisia, Indochina, West and Equatorial Africa, Togo, Cameroon, and Madagascar), and labor tax redemptions. 


\section{External trade taxes (re_trade)}

External trade taxes comprise export taxes (re_trade_exp) and import taxes (re_trade_imp), as well as harbor dues not attributable to export or import taxes (octroi de mer in Algeria). Taxes on the consumption of imported products are considered as import taxes (re_trade_imp).

\section{Intermediate taxes (re_intermediate)}

Intermediate taxes comprise taxes with an element of proportionality, but which do not require the frequently collection of statistical information on firms or individuals. They include direct intermediate taxes (re_interm_di), such as land taxes and business licenses (patente), and indirect intermediate taxes (re_interm_in), such as circulation taxes and taxes on the consumption of specific luxury goods (alcohol, sugar, tobacco).

\section{Modern taxes (re_modern)}

Modern taxes comprise taxes which require the frequent collection or self-declaration of detailed economic information on individuals and firms. Direct modern taxes (re_modern_di) are personal income taxes (impôt sur le revenu, as well as the Moroccan tax on agricultural income called tertib), taxes on benefits, and the tax on interests and dividends (impôt sur le revenu des valeurs mobilières). Indirect modern taxes (re_modern_in) are broad-based consumption taxes, taxes on sales revenue (impôts sur le chiffre d'affaire), and turnover taxes (called taxes sur la production, taxe unique à la production in Algeria, and taxe sur les transactions in Tunisia).

\section{Monopoly revenue (re_monopoly)}

Monopoly revenue includes revenue from any economic activity on which the government had a legal monopoly. It comprises revenue from industrial operations (including post and telegraph receipts) and administrative services, and revenue from the sale of various goods on which the colonial government had a monopoly, such as salt (in Tunisia and Indochina), tobacco (in Morocco, Tunisia, Indochina, and Madagascar), alcohol (in Madagascar and Indochina), and opium (in Indochina). It also includes excess revenue of public railway companies transferred to the government's budget, as well as various registration fees. 


\section{Other sources of internal revenue (re_other)}

Other sources of internal revenue are the difference between Net public revenue (NPR) and the sum of all previous sources of internal revenue: head taxes, monopoly revenue, external trade taxes, intermediate taxes, modern taxes. Revenue collected in the current fiscal year on account of the previous fiscal year's budget (Recettes d'exercices antérieurs / d'exercices clos) is allocated between the different items of revenue in proportion of their weight in total revenue.

\section{Net surplus/deficit (deficit)}

Net surplus/deficit is the difference between net public revenue and net public expenditure (deficit $=N P R-N P E)$. The net deficit is, by construction, financed by net transfers from reserve funds, net borrowing, and net subsidies (another way to put it is that the net surplus is composed of net transfers to reserve funds, net loans, and net subsidies given out). Unfortunately, net transfers from reserve funds cannot be systematically computed, but we provide variables for the other components of the net deficit.

\section{Net subsidies (netsubto)}

Net subsidies are subsidies received from abroad net of subsidies sent abroad. During the colonial period, the bulk of net subsidies are net subsidies from metropolitan France (netsubfr), equal to subsidies from France to the colony minus subsidies from the colony to France. After 1960, net subsidies are aid grants from OECD-DAC aid data

\section{Net borrowing (netborto)}

Net borrowing per capita is equal to loans received minus loans given out, minus interests and reimbursements paid out, plus interests and reimbursements paid in. After 1960, net borrowing is net loan aid from OECD-DAC aid data.

\section{NPE of first-level administrative divisions (NPE_adm1)}

First level administrative divisions are départements in Algeria, régions in Morocco, and provinces in Indochina and Madagascar. Their expenditure is already taken into account in the consolidated aggregate (NPE). 


\section{NPR of first-level administrative divisions (NPR_adm1)}

First level administrative divisions are départements in Algeria, régions in Morocco, and provinces in Indochina and Madagascar. Their revenue is already taken into account in the consolidated aggregate (NPR).

\section{Tax revenue of first-level administrative divisions (tax_adm1)}

First level administrative divisions are départements in Algeria, régions in Morocco, and provinces in Indochina and Madagascar. The tax revenue of first level administrative divisions is already taken into account in the consolidated aggregate (NPR). Tax revenue of the central government only is simplytaxrevenue $\operatorname{tax}_{a} d m 1$.

\section{NPE of second-level administrative divisions (NPE_adm2)}

Second-level administrative divisions are municipalities (communes). Their expenditure is not taken into account in the consolidated aggregate (NPE), because it is often missing. NPE_adm2 is net of all transfers, including subsidies from the central government and first-level administrative divisions.

\section{NPR of second-level administrative divisions (NPR_adm2)}

Second-level administrative divisions are municipalities (communes). Their revenue is not taken into account in the consolidated aggregate (NPR), because it is often missing. NPR_adm2 is net of all transfers, including subsidies to the central government and first-level administrative divisions.

\section{Net subsidies from central government to municipalities (sub_gcadm2) and from} municipalities to central government (sub_adm2_gc)

For years in which NPE_adm2 and NPR_adm2 are not missing, it is possible to compute total consolidated public expenditure and revenue. When computing total net public expenditure and revenue, one should subtract from net public expenditure the subsidies to municipalities (sub_gcadm2), and subtract from net public revenue the transfers from municipalities (sub_adm2gc). NPE_adm2 and NPR_adm2, however, are already net of transfers to and from the central government and first-level administrative divisions. Denoting with a star total consolidated net public expenditure and revenue, we have $N P E^{*}=N P E-s u b_{g} c a d m 2+N P E_{a} d m 2$, and $N P R^{*}=$ $N P R-s u b_{a} d m 2 g c+N P R_{a} d m 2$. 


\section{Social security transfers (re_socsec and exp_socsec)}

Social security transfers are not part of net public expenditure (NPE) and net public revenue (NPR). There were no social security transfers in the colonies before World War II. In 1945, social security funds were created in the colonies and protectorate of North Africa. The variable re_socsec gives social security contributions and the variable exp_socsec social security benefits.

\section{Total population (pop)}

See section "Population, prices, and GDP” above and the "List of sources” below.

\section{European population (pop_eu)}

See section "Population, prices, and GDP" above and the "List of sources" below. In Algeria, European population includes Jews who were given French citizenship by the 1870 Crémieux decree. In Morocco and Tunisia, Jews were not given French citizenship and are included in the non-European minority population (pop_min). In Indochina, European population comprises a small number of Japanese and Americans.

\section{Non-European minority population (pop_min)}

See section "Population, prices, and GDP" above and the "List of sources" below. Non-European minority population is Jewish population in North Africa (except in Algeria where Jews were given French citizenship), Chinese population in Indochina, and Asian (Chinese and Indian) population in Madagascar.

\section{Share of 15-64-year-olds (share1564)}

See section "Population, prices, and GDP" above and the "List of sources" below. The population share of 15-64 year-olds is estimated only in 1925, 1945 and 1955. In North Africa and Indochina, we estimate the share of 15-64-year-olds in the Autochthonous population (share1564_au) and in the European population (share1564_eu).

\section{Price deflator (deflator)}

See section "Population, prices, and GDP" above and the "List of sources" below. The price deflator, base 1 in 1937, was used to deflate nominal amounts, along with the PPP adjustor. All public finance variables are given per head in 1937 PPP Francs. To recover nominal amounts, one needs to divide by deflator and by PPP_adjustor. In 
West Africa after 1960, doing so will produce a nominal amount in current CFA francs (Mali, Mauritania and Guinée went off the CFA franc after 1960, but we converted all nominal amounts in CFA francs for these countries before applying the regional deflator).

\section{Purchasing power parity adjustor (PPP_adjustor)}

See section "Population, prices, and GDP" above and the "List of sources" below. The PPP adjustor adjusts for purchasing power parity in 1937. All public finance variables are given per head in 1937 PPP Francs. To recover nominal amounts, one needs to divide by deflator and by PPP_adjustor. In West Africa after 1960, doing so will produce a nominal amount in current CFA francs (Mali, Mauritania and Guinée went off the CFA franc after 1960, but we converted all nominal amounts in CFA francs for these countries before applying the regional deflator).

\section{GDP per capita in 1937 PPP francs (GDP)}

The many assumptions behind the building of yearly GDP per capita figures are laid out in details in the section "Population, prices and GDP" above. We used the same deflator to deflate nominal GDP and public finance figures, so that GDP shares can be computed directly by dividing the relevant variable by GDP.

\section{PERSONNEL DATABASE}

\section{Region}

One of nine colonies, protectorates, mandates, or federations or colonies: Algeria, Morocco, Tunisia, Indochina, West Africa, Togo, Equatorial Africa, Cameroon, and Madagascar.

\section{Year}

\section{Total revenue (re_to)}

Total revenue, not consolidated. This is simply the sum of gross revenue over all the budget accounts (federal and colonial) in the region.

\section{Total expenditure (exp_to)}

Total expenditure, not consolidated. This is simply the sum of gross expenditure over all the budget accounts (federal and colonial) in the region. 


\section{Average wage of government employees (avwage_to)}

Average wage of government employees, all sectors, including bonuses and allowances, in 1937 PPP Francs. Computed by dividing total personnel expenditure attached to a given number of employees by the number employees. Government is only colonial government in colonies, federal and colonial governments in federations of colonies, excluding the local governments of first- and second-level administrative divisions.

\section{Total number of government employees per 1,000 inhabitants (nbemppc_to)}

Total number of employees is the sum of total number of enumerated employees and estimated number of employees when items of personnel expenditure are not attached to a precise number (the monetary amount is divided by the average wage). Government is only colonial government in colonies, federal and colonial governments in federations of colonies, excluding the local governments of first- and second-level administrative divisions.

\section{Average wage and number of employees by sector}

Average wages are in 1937 PPP francs (divide by deflator and PPP_adjustor to recover the nominal wage). Number of employees is given per 1,000 inhabitants (multiply by pop to recover the actual number of employees). The definition of each sector corresponds exactly to the definition given in the variable dictionary for the public finance database.

Total population (pop), share of 15-64-year-olds (share1564), price deflator (deflator), purchasing power parity adjustor (PPP_adjustor), GDP per capita (GDP)

See definition in the variable dictionary for the public finance database.

\section{LIST OF SOURCES}

To build our public finances and personnel database, we gathered data from around 1,700 official publications. These publications were accessed in several libraries and public archives: the Bibliothèque Nationale de France $(\mathrm{BnF})$ in Paris, the Bibliothèque Universitaire des Langues et Civilisations (BULAC) in Paris, the Bibliothèque Cujas (BC) in Paris, the Bibliothèque de documentation internationale contemporaine (BDIC) in Nanterre, the Centre des Archives Economiques et Financières (CAEF) in Savigny-le-Temple, the Bibliothèque Universitaire de Grenoble (BUG) in Grenoble, and the Centre des Archives de l'Outre-Mer 
(CAOM) in Aix-en-Provence. We indicate in brackets the place (or places) where we accessed the source and the location number, when relevant. For the Bibliothèque Nationale de France, a location number starting with NUMP indicates that the publication was digitized and made available on the BnF's digital library Gallica (www.gallica.bnf.fr). If no location number is indicated, the source comes from a private collection. When a series of publication was printed by several publishers, we give only the first publisher and place of publication.

\section{PUBLIC FINANCES}

\section{Metropolitan France}

André, Christine and Delorme, Robert. L'Etat et l'économie. Un essai d'explication de l'évolution des dépenses publiques en France (1870-1980). Paris: Seuil, 1983.

INSEE (Institut national de la statistique et des études économiques). Annuaire statistique de la France, résumé rétrospectif. Paris, 1966. [BnF: NUMP-10025]

France, Ministère de la France d'Outre-mer, Service des statistiques. Annuaire statistique de l’Union française outre-mer. Paris: Impr. nationale, 1951. [4-LC25-321 (2)]

France, Ministère des affaires économiques et financières, Secrétariat d'Etat aux postes, télégraphes et téléphones. Rapport sur la gestion financière des services pendants l'année 1955. Paris: Imprimerie des journaux officiels, 1957. [BnF: FOL-LF186-443]

France, Ministère du commerce et de l'industrie. Rapport sur la gestion financière et la marche générale des services des postes, télégraphes et téléphones pendant l'année 1925. Paris: Imprimerie des journaux officiels, 1927. [BnF: NUMP-16601]

Budget accounts of the Ministry of the Navy and Ministry of the Colonies

France, Ministère de la marine et des colonies. Compte définitif des dépenses de l'exercice... Paris : Impr. royale, then Impr. nationale, 1833-1938. [BnF: 4-LF224-7]

France, Ministère des colonies. Compte définitif des dépenses de l'exercice... Paris, 18841938. [BnF: 4-LF224-119]

France, Ministère de la France d'Outre-Mer (services civils et militaires). Compte définitif des dépenses de l'exercice... Paris : Impr. nationale, 1953-1954, 1955-1959 [BnF : FOL-LF156184, CAEF]

\section{Budget accounts of the Ministry of Defense}

France, Ministère de la guerre. Comptes généraux présentés par le ministre de la guerre pour l'exercice... Paris: Impr. royale, then Impr. nationale, 1819, 1821-1937. [BnF: NUMP-3685 \& 4-LF194-10, CAEF]

France. Ministère de la Défense. Compte définitif des dépenses. Paris, 1946, 1955. [CAEF]

Budget accounts of the Ministry of the Sahara

France, Ministère du Sahara. Loi de finance, compte définitif. 1958-1962. [BnF: FOL-LF156184] 


\section{Algeria}

\section{Statistical abstracts}

Algeria, Gouvernement général civil. Statistique générale de l’Algérie. Algiers: Impr. de l'Association ouvrière, various dates between 1867 and 1925. [BnF: LK8-1043]. (The second volume for the year 1900 contains retrospective data from 1830, as well as communal and departmental data.)

Algeria, Sous-direction des statistiques. Annuaire statistique de l'Algérie. Algiers: Impr. Administrative Emile Pfister, various dates between 1926 and 1960. [BnF: 4-O3W-583]

Algeria. Statistique financière de l'Algérie. Algérie du Nord et territoires du Sud. Algiers: Impr. agricole et commerciale, 1900-1902, 1904-1905, 1909-1932, 1934-1935, 1937. [BnF: NUMP-3485]

Algeria, Service de statistique générale. Statistique générale de l'Algérie. Tableau de l'économie Algérienne. Algiers: Impr. Baconnier, 1958. [BnF: 16-LC32-174]

Definitive budget accounts

Algeria. Compte définitif des dépenses de l'exercice... Paris: Impr. Impériale, then Nationale, 1858-1880. [BnF : 4-LF269-3]

Algeria. Compte définitif des recettes du budget de l'Algérie pour l'exercice... Algiers: Impr. Algérienne, various dates between 1914 and 1957. [BnF: NUMP-4918, CAEF]

Algeria. Budget de l'Algérie. Compte définitif des dépenses de l'exercice... Algiers: Impr. Algérienne, various dates between 1914 and 1957. [BnF : NUMP-3572, CAEF]

\section{Provisional budget accounts}

Algeria. Projet de budget... - Gouvernement général de l'Algérie. Algiers: Impr. de V. Heintz, 1925, 1937, 1955-1956. [BnF: FOL-LK19-400 \& NUMP-3535]

Algeria. Délégation générale en Algérie. Services civils en Algérie. Budget voté de 1960. Algiers: Impr. officielle, 1960. [BnF: 4-LF156-200]

Auxiliary budget accounts

Algeria, Gouvernement général de l'Algérie. Budget annexe des postes, télégraphes et téléphone de l'Algérie : Compte définitif des résultats de l'exercice... Algiers: J. Carbonel, 1927-1939. [BnF: FOL-LK19-609 \& NUMP-4652]

Algeria, Gouvernement général de l’Algérie. Budget annexe des postes, télégraphes et téléphone des territoires du Sud: Compte définitif des résultats de l'exercice... Algiers: J. Carbonel, 1927-1939. [BnF: FOL-LK19-609 \& NUMP-4652]

\section{Morocco}

\section{Statistical Abstracts}

Morocco. Annuaire économique et financier. Casablanca: Impr. G. Mercié, various dates between 1917 and 1929. [BULAC: BIULO PER.5552]

Morocco, Direction générale de l'agriculture, du commerce et de la colonisation. Annuaire de statistique générale du Maroc. Casablanca: Impr. réunies de la Vigie Marocaine et du Petit Marocain, various dates between 1925 and 1936. [BULAC: BIULO PER.6096] 
Morocco, Direction de l'industrie. Annuaire de statistique générale de la zone française du Maroc. Casablanca: Impr. réunies de la Vigie Marocaine et du Petit Marocain, various dates between 1937 and 1953. [BDIC: Q6400]

Morocco, Royaume du Maroc, Ministère de l'Economie Nationale, Division de la Coordination Economique et du Plan, Service Central des Statistiques. Tableaux économiques du Maroc, 1915-1959. Rabat, 1960.

Provisional budget accounts

Morocco. Empire Chérifien. Protectorat français. Budget de l'exercice... Various dates between 1925 and 1955. [CAEF: F4120]

\section{Tunisia}

\section{Statistical abstracts}

Tunisia. Statistique générale de la Tunisie. Tunis, various dates between 1881 and 1939. [BnF: NUMP-7491 \& MFILM 8-O3I-371]

Tunisia, Institut national de la statistique. Annuaire statistique de la Tunisie. Tunis: Institut national de la statistique, various dates between 1940 and 1999. [BnF: 4-O3W-35, 8-SG PER U-160 \& MICROFICHE M-25451]

Provisional budget accounts

Tunisia. Budget Général de la Tunisie. Various dates between 1931 and 1952. [CAEF]

Tunisia. Régence de Tunis. Protectorat français. Budget de l'Etat et des Etablissements publics annexes pour l'exercice... Various dates between 1912 and 1955-56. [CAEF: 4329]

Tunisia. Régence de Tunis. Protectorat français. Projet de budget de l'Etat pour l'exercice 1924. [CAEF: F4473]

\section{Other}

Tunisia. Rapport au Président de la République sur la situation de la Tunisie. Paris: Imprimerie nationale, 1890-1916, 1918-1925, 1927, 1929, 1931, 1934. [BnF: NUMP-11318]

Tunisia. Rapport au Président de la République sur la situation de la Tunisie. Paris: Imprimerie Nationale, 1938. [CAEF]

\section{Indochina}

\section{Statistical abstracts}

Indochine française, Bureau de la statistique générale. Annuaire Statistique de L'Indochine .... Hanoï: Impr. d'Extrême-Orient, various dates between 1927 and 1949. [BnF: MICROFILM M-14883]

Annuaire statistique du Laos. Troisième volume. 1951-1952. Saigon: Vo-Van-Van, 1954. [BDIC: Q15925]

Federal budget accounts — definitive

Indochine, Gouvernement général. Compte Administratif du Budget Général. Saïgon: Impr. Colonial, various dates between 1900 and 1913. [BC: 9.915-2] 
Indochine, Gouvernement général. Compte Administratif du Budget Général de l'Indochine pour l'exercice ... Hanoï-Haïphong: Impr. d'Extrême Orient, 1911-1943, 1946-1949. [BnF: NUMP-3483 \& FOL-LK19-547]

Federal budget accounts — provisional

Indochine, Gouvernement général. Budget Général pour l'exercice... Hanoï: F.-H. Schneider, various dates between 1904 and 1913. [BC: 9.915-5]

Indochine française, Haut-commissariat. Budget général : exercice... Hanoï, then Haïphong: Impr. d'Extrême-Orient, 1914, 1925. [BnF: FOL-LK19-482]

Indochine française. Projet de budget général : exercice 1937. Hanoï: Impr. d’ExtrêmeOrient, 1937. [BnF: NUMP-4948]

Colonial budget accounts: Annam (Centre Vietnam) - definitive

Annam. Compte administratif du budget local de l'Annam pour l'exercice... Various places: Impr. d'Extrême-Orient, 1894, 1896, 1899, 1904, 1905, 1910-1943. [BnF: MFILM LK19478]

Colonial budget accounts: Annam (Centre Vietnam) - provisional

Annam. Budget local de l'Annam pour l'exercice... Various places, 1887-1893, 1897, 18991945. [BnF: MFILM FOL-LK19-479]. (Contains the provisional budget accounts of Tonkin for the years 1887-1890 and 1897.)

Vietnam. Budget Régional du Centre Vietnam pour l'exercice 1953. [BnF: FOL-O2W-19]

Colonial budget accounts: Cochinchina (South Vietnam) — definitive

Cochinchina. Compte administratif du budget local de la Cochinchine pour l'exercice... Saïgon, 1871-1891, 1893-1906, 1915-1941, 1943. [BnF: NUMP-3524 \& FOL-LK19-633]

Colonial budget accounts: Cochinchina (South Vietnam) - provisional

Cochinchina. Budget local de la Cochinchine pour l'exercice... Saïgon: Impr. du Gouvernement, 1876, 1878-1901, 1921-1922, 1924, 1927-1942, 1944. [BnF: NUMP-3149 \& LK19-124, BC: 9.899]

Colonial budget accounts: Tonkin (North Vietnam) - definitive

Tonkin. Compte administratif du budget local du Tonkin pour l'exercice... Hanoï : Impr. Tonkinoise, 1900-1923, 1925-1943. [BnF: NUMP-3451 \& 4-LK19-539]

Colonial budget accounts: Tonkin (North Vietnam) — provisional

Tonkin. Budget local du Tonkin pour l'exercice... Hanoï-Haïphong, various dates between 1898 and 1944. [BnF: MFILM FOL-LK19-480]

Vietnam. Budget Régional du Nord Vietnam pour l'exercice 1953. Impr. nationale du ViêtNam, 1952. [BnF: GR FOL-O2W-1]

Colonial budget accounts: Vietnam (after 1945)

Vietnam. Budget National de l'Etat du Vietnam pour l'exercice 1953. Saïgon: Impr. française d'Outre-mer, 1952. [BnF: 4-O2W-40] 
Colonial budget accounts: Cambodia - definitive

Cambodia. Compte administratif du budget local du Cambodge pour l'exercice... PnomhPenh: Impr. A. Portail, 1904-1907, 1910-1943. [BnF: MFILM LK19-476]

Colonial budget accounts: Cambodia - provisional

Cambodia. Budget local du Cambodge pour l'exercice... Various places, 1883, 1884, 18881945. [FOL-LK19-311]

Cambodia. Budget National du Cambodge pour l'exercice... 1950, 1952-1954. [BnF: FOLO2W-16]

Colonial budget accounts: Laos — definitive

Laos. Compte administratif du budget local du Laos pour l'exercice... Various places and publishers, 1904-1907, 1910-1921, 1923-1942. [BnF: NUMP-3514 \& FOL-LK19-594]

Colonial budget accounts: Laos — provisional

Laos. Budget local du Laos pour l'exercice... Hanoï: Impr. d’Extrême-Orient, 1897-1943. [BnF: NUMP-3481 \& FOL-LK19-528]

Laos. Budget National du Laos pour l'exercice... Hanoï: Impr. d’Extrême-Orient, 1950, 195254. [BnF: FOL-O2W-17]

Auxiliary budget accounts

Indochine française. Budget de l'emprunt de 53 millions pour l'exercice 1915. [BC: 9.915-6a]

France, Inspection générale des Travaux publics. Budget de l'emprunt de 90 millions pour l'exercice... Hanoï-Haïphong: Impr. d’Extrême-Orient, 1913, 1914. [BC: 9.915-7]

Indochine française. Budget de l'emprunt de 90 millions pour l'exercice... Hanoï-Haïphong: Impr. d’Extrême-Orient, 1917, 1922-1929. [BnF: NUMP-3463 \& 4-LK19-534]

Indochine française. Compte administratif du budget de l'emprunt de 90 millions pour l'exercice... Hanoï-Haïphong: Impr. d'Extrême-Orient. 1922, 1923, 1925-1929. [BnF: NUMP-3869 \& FOL-LK19-550]

Indochine française. Compte administratif du budget de l'emprunt de 6180000 piastres pour l'exercice... Hanoï: Impr. d’Extrême-Orient, 1922-1927. [BnF: FOL-LK19-540 (BIS)]

Indochine française. Budget spécial sur fonds d'emprunt des grands travaux et dépenses sanitaires pour l'exercice... Hanoï: Impr. d'Extrême-Orient, 1931-1942, 1945. [NUMP-4136 \& FOL-LK19-642]

Indochine française. Compte administratif du budget spécial sur fonds d'emprunt des grands travaux et dépenses sanitaires pour l'exercice... Hanoï: Impr. d'Extrême-Orient, 1913-1943. [BnF: NUMP-4822 \& FOL-LK19-697]

Indochine française. Compte Administratif du Budget spécial pour la reconstruction et le rééquipement de l'Indochine pour l'exercice 1946. Hanoï-Haïphong: Impr. d'Extrême-Orient, 1946. [BnF: FOL-LK19-547]

Other (notably for provincial and municipal budget accounts)

Spooner, Andrew. Situation financière en Cochinchine. Unknown place, 1874. [BnF: NUMM-5842883 \& 4-LK10-90] 
Indochine française. Rapports au Conseil Supérieur (Gouverment général de l'Indochine). Hanoï-Haïphong: Impr. d'Extrême-Orient, 1910-1939. [BnF: NUMP-3209 \& 4-LK19-463]

Indochine française. Rapport sur la situation administrative, économique et financière au Laos durant la période... Hanoï: Impr. d’Extrême-Orient, 1929-1939. [BnF: NUMP-3424 \& 4-LK19-611]

Ville de Hanoï : bulletin municipal. Hanoï: unknown publisher, 1916, 1922-1924. [BnF: NUMP-4440 \& 8-LK19-565]

\section{Afrique Occidentale Française}

Federal budget accounts - definitive

Afrique occidentale française. Compte définitif des recettes et dépenses du budget général de l'Afrique occidentale française pour l'exercice... Gorée, then Rufisque: Impr. du Gouvernement general, 1905-1939, 1941-1957. [BnF: NUMP-3506 \& FOL-LK19-398]

Federal budget accounts - provisional

Afrique Occidentale Française. Budget général de l'Afrique occidentale française... Various places: Impr. du Gouvernement général, 1913, 1925, 1936, 1949, 1955. [BnF: FOL-LK19372 \& NUMP-3509]

Colonial budget accounts: Côte d'Ivoire - definitive

Côte d'Ivoire. Compte définitif des recettes et dépenses du budget local de la Côte d'Ivoire pour l'exercice... Bingerville, then Abidjan: Impr. du Gouvernement, 1901-1904, 1906-1915, 1917-1921, 1923-1924, 1928-1940, 1942-1943, 1945-1954. [BnF: FOL-LK19-404]

Colonial budget accounts: Côte d'Ivoire - provisional

Côte d'Ivoire. Budget du service local de la Côte d'Ivoire pour l'exercice... Various places and publishers, various dates between 1893 and1960. [BnF: FOL-LK19-407 \& NUMP-3512, BC: 9.882-1]

Colonial budget accounts: Dahomey — definitive

Dahomey. Compte définitif des recettes et dépenses du budget local du Dahomey pour l'exercice... Porto-Novo: Impr. du Gouvernement, 1897-1902, 1904, 1906, 1908-1938, 1940 1942, 1944-1955. [BnF: NUMP-3480 \& FOL-LK19-412]

Colonial budget accounts: Dahomey — provisional

Dahomey. Budget local du Dahomey pour l'exercice... Porto-Novo: Impr. du Gouvernement, 1895-1898, 1900-1945, 1947-1957. [BnF: NUMP-3288 \& 4-LK19-409]

Colonial budget accounts: Guinea - definitive

Guinea. Compte définitif des recettes et dépenses du budget local de la Guinée pour l'exercice... Conakry: Impr. du Gouvernement, 1890-1902, 1904-1940, 1942-1943, 19461954. [BnF: NUMP-3543 \& FOL-LK19-390]

Colonial budget accounts: Guinea - provisional

Guinea. Budget local de la Guinée française pour l'exercice... Conakry: Impr. du Gouvernement, 1892, 1894-1955, 1958. [BnF: NUMP-3409 \& FOL-LK19-269] 
Colonial budget accounts: Haute-Volta — definitive

Haute-Volta. Compte définitif des recettes et dépenses du budget local de la Haute-Volta pour l'exercice... Koulouba: Impr. du Gouvernement, 1920-1922, 1929-1932, 1948-1954, 1956. [BnF: NUMP-3534 \& FOL-LK19-515]

Colonial budget accounts: Haute-Volta - provisional

Haute-Volta. Budget local de la Haute-Volta pour l'exercice... Koulouba: Impr. du Gouvernement, 1920-1928, 1931-1932, 1938-1956. [BnF: NUMP-3387 \& FOL-LK19-501]

Colonial budget accounts: Mauritania - definitive

Mauritania. Compte définitif des recettes et dépenses du budget local de la Mauritanie pour l'exercice... Gorée, then Rufisque: Impr. du Gouvernement general, 1906-1955. [BnF: NUMP-3127 \& 4-LK19-419]

Colonial budget accounts: Mauritania — provisional

Mauritania. Budget local de la Mauritanie pour l'exercice... Gorée, then Rufisque: Impr. du Gouvernement general, 1908-1914, 1915-1940, 1942, 1946-1958. [BnF: FOL-LK19-447]

Colonial budget accounts: Niger — definitive

Niger. Compte définitif des recettes et dépenses de la colonie du Niger pour l'exercice... Gorée, then Koulouba: Impr. du gouvernement (général), various dates between 1921 and 1955. [BnF: FOL-LK19-569]

Colonial budget accounts: Niger — provisional

Niger. Budget local du Territoire militaire du Niger pour l'exercice... (title varies). Various places and publishers, 1913-1958. [BnF: FOL-LK19-408 (BIS)]

Colonial budget accounts: Senegal — definitive

Senegal. Compte définitif des recettes et dépenses du budget local du Sénégal Pays de Protectorat pour l'exercice... Saint-Louis: Impr. du Gouvernement, 1905-1914, 1916-1936. [BnF: NUMP-3098 \& FOL-LK19-441]

Senegal. Compte définitif des recettes et dépenses du budget local du Sénégal pour l'exercice... Saint-Louis: Impr. du Gouvernement, 1873, 1875-1890, 1892-1893, 1895-1896, 1898, 1900-1901, 1905-1959. [BnF: NUMP-3403, NUMP-3134, FOL-LK19-142, FOLLK19-440 \& FOL-LK19-441]

Colonial budget accounts: Senegal — provisional

Senegal. Budget local de la colonie du Sénégal pour l'exercice... Saint-Louis: Impr. du Gouvernement, 1905-1920, 1922-1943, 1945-1946, 1948-1958. [BnF: NUMP-3407 \& FOLLK19-405]

Colonial budget accounts: Soudan and predecessors — definitive

Haut-Sénégal-Niger. Compte définitif des recettes et dépenses du budget local du HautSénégal et Moyen-Niger pour l'exercice... Bamako: Impr. du Gouvernement, 1902, 19081914, 1916-1919. [BnF: NUMP-11411 \& FOL-LK19-373] 
Soudan français. Compte définitif des recettes et dépenses du budget local du Soudan français pour l'exercice... Koulouba: Impr. du gouvernement, various dates between 1945 and 1951. [BnF: FOL-LK19-530]

Colonial budget accounts: Soudan and predecessors - provisional

Afrique occidentale française. Budget local du Haut-Sénégal et Niger : exercice... Bamako, 1901, 1902. [BC: 9.955-2]

Haut-Sénégal-Niger. Budget local du Haut-Sénégal et Niger (title varies). Various places: Impr. du Gouvernement (général), 1903-1920. [BnF: NUMP-3306, 4-LK19-363 \& 4-LK19408]

Soudan français. Soudan français, budget du service local, exercice... Saint-Louis: Imprimerie du Gouvernement, 1898-1899. [BnF: NUMP-3445 \& FOL-LK19-507]

Afrique occidentale française. Budget du service local. Soudan français : exercice... SaintLouis: Impr. du Gouvernement, 1898-1899. [BC: 9.955-1]

Soudan français. Budget local du Soudan français pour l'exercice... Bamako, then Koulouba: Impr. du Gouvernement, 1921-1941, 1943-1960. [BnF: NUMP-3445 \& FOL-LK19-507]

Auxiliary budget accounts

Afrique occidentale française. Gouvernement général de l'Afrique occidentale française. Budget des fonds d'emprunt... Emprunt de 65 millions. Gorée: Impr. du Gouvernement general, 1909-1912. [BnF: NUMP-7005 \& 4-LK19-451]

Afrique occidentale française. Gouvernement général de l'Afrique occidentale française. Budget des fonds d'emprunt... Emprunt de 14 millions... chemin de fer de Thiès vers Kayes. Gorée: Impr. du Gouvernement general, 1910-1917. [BnF: NUMP-3467 \& FOL-LK19-423]

Afrique occidentale française. Gouvernement général de l'Afrique occidentale française. Budget des fonds d'emprunt... Emprunt de 167 millions. Gorée: Impr. du Gouvernement general, 1914-1926. [BnF: NUMP-8145 \& 4-LK19-452]

Afrique occidentale française. Gouvernement général de l'Afrique occidentale française. Budget spécial des grands travaux et dépenses sanitaires sur fonds d'emprunt, annexe au budget général. Exercice... Gorée, Rufisque: Impr. du gouvernement general, 1932-1941, 1946. [BnF: NUMP-3530 \& FOL-LK19-636]

Afrique occidentale française. Gouvernement général de l'Afrique occidentale française. Compte définitif des recettes et des dépenses du budget des fonds des emprunts de 65 et 100 millions. Gorée: Impr. du Gouvernement general, 1906-1923. [BnF: FOL-LK19-455]

Afrique occidentale française. Gouvernement général de l'Afrique occidentale française. Compte définitif des recettes et des dépenses du budget des fonds de l'emprunt de 100 millions. Various places, 1908-1912. [BnF: FOL-LK19-456]

Afrique occidentale française. Gouvernement général de l'Afrique occidentale française. Compte définitif des recettes et des dépenses du budget des fonds de l'emprunt de 14 millions. Various places, 1910-1917. [BnF: FOL-LK19-467]

Afrique occidentale française. Gouvernement général de l'Afrique occidentale française. Compte définitif des recettes et des dépenses du budget des fonds de l'emprunt de 14 et 167 millions. Various places, 1914-1926. [BnF: FOL-LK19-492] 
Afrique occidentale française. Compte définitif des recettes et des dépenses du budget spécial des grands travaux et dépenses sanitaires sur fonds d'emprunt : annexe au budget général : exercice... Rufisque: Impr. du Gouvernement general, 1931-1937, 1939-1941, 1944-1946. [BnF: NUMPR-7653 \& FOL-LK19-684]

\section{Other}

Dakar (Circonscription). Budget de la circonscription de Dakar et dépendances (annexe au bidget général). Exercice... Gorée, then Rufisque: Impr. Du Gouvernement general, 19251944, 1946-1947. [NUMP-3533 \& FOL-LK19-535]

\section{Togo}

\section{Colonial budget accounts - definitive}

Togo. Compte définitif des recettes et dépenses du budget local du Togo pour l'exercice... 1923-1938, 1947, 1950, 1952. [BnF: FOL-LK19-857]

\section{Colonial budget accounts - provisional}

Togo. Budget local du Togo pour l'exercice... Gorée: Impr. du Gouvernement général. 19201922, 1924-1944, 1947-1950, 1952-1954, 1956. [BnF: NUMP-3562 \& FOL-LK19-504]

\section{Afrique Equatoriale Française}

\section{Statistical abstracts}

Afrique Equatoriale Française, Service de la statistique générale. Annuaire statistique de l'Afrique équatoriale française. Volume 1936-1950. 1952. [BnF: 4-LC32-158]

Oubangui-Chari, Bureau de la Statistique générale. Annuaire statistique de l'Oubangui-Chari. Années 1940 à 1955. Vol. 1. Bangui: Impr. Notre-Dame, 1957. [BnF: 4-LC32-182]

Federal budget accounts - definitive

Congo Français. Compte définitif des recettes et des dépenses. Libreville: Imprimerie du Gouvernement, 1899-1908. [BnF : FOL-LK19-387]

Afrique Equatoriale Française. Compte définitif des recettes et des dépenses. Brazzaville: Imprimerie du Gouvernement Général, 1912-1958. [BnF : NUMP-3385 \& 4-LK19-434]. (This location number also covers colonial budget accounts for some dates).

Federal budget accounts — provisional

Afrique Equatoriale Française. Projets de budgets exercice... (title varies). Brazzaville: Impr. du Gouvernement general, 1912, 1915, 1917. [BnF: FOL-LK19-469 \& NUMP-3508]. (This location number also covers colonial budget accounts for some dates).

Afrique Equatoriale Française. Budget général... Brazzaville: Imprimerie du Gouvernement, various dates between 1911 and 1958. [BnF: FOL-LK19-778 \& NUMP-3428]. (This location number also covers colonial budget accounts for some dates).

Colonial budget accounts: Moyen-Congo — definitive

Afrique Equatoriale Française. Budget local du territoire du Moyen-Congo : compte définitif des recettes et des dépenses. Exercice... Brazzaville: Impr. Officielle du gouvernement general, 1927-1956. [BnF: NUMP-3520 \& FOL-LK19-579] 
Colonial budget accounts: Moyen-Congo — provisional

Congo. Budget local: exercice... / Gouvernement général de l'Afrique équatoriale française, Territoire du Moyen-Congo. Brazzaville: Impr. du Gouvernement général, various dates between 1947 and 1960. [BnF: FOL-LK19-773]

Colonial budget accounts : Gabon — definitive

Afrique Equatoriale Française. Comptes définitifs des recettes et des dépenses : budget local du Gabon : exercice... Paris, then Brazzaville: E. Larose, then Impr. Du Gouvernement, 1920-1921, 1925-1926, 1933, 1952-53. [BnF : NUMP-3546 \& FOL-LK19-578]

Colonial budget accounts : Gabon - provisional

Gabon. Budget local : exercice... / Afrique équatoriale française, Territoire du Gabon. Various places and publishers, various dates between 1890 and 1958. [BnF: FOL-LK19-371, FOL-LK19-778 \& FOL-LK19-796]

Colonial budget accounts : Oubangui-Chari - definitive

Afrique Equatoriale Française. Oubangui-Chari. Compte définitif des recettes et des dépenses : budget local : exercice... . Paris : E. Larose, 1925, 1926, 1951. [BnF: NUMP-3526 \& FOL-LK19-576]

Colonial budget accounts : Oubangui-Chari — provisional

Oubangui-Chari. Budget local : exercice... / Afrique équatoriale française, Oubangui-Chari. Various places and publishers, various dates between 1900 and 1959. [BnF: FOL-LK19-371, FLO-LK19-778, FOL-LK19-802]

Colonial budget accounts : Chad - definitive

Chad. Compte définitif des recettes et des dépenses. Exercice... Paris, then Brazzaville: E. Larose, then Impr. officielle, 1925, 1926, 1947, 1949-1954. [BnF : FOL-LK19-580]

Colonial budget accounts : Chad - provisional

Chad. Afrique équatoriale française. Territoire du Tchad. Budget local. Exercice... Various places and publishers, 1951-1958. [FOL-LK19-858]

\section{Cameroon}

Definitive budget accounts

Cameroon. Compte définitif des recettes et dépenses du budget des territoires du Cameroun pour l'exercice... Paris: E. Larose, 1922-1925, 1929-1931, 1933-1936, 1945-1952. [BnF: NUMP-3573 \& FOL-LK19-536]

Provisional budget accounts

Cameroon. Budget du Cameroun : exercice... Yaounde: Impr. du Gouvernement, 1920, 1922, 1924-1926, 1929-1939, 1943, 1945-1957. [BnF: NUMP-3511 \& FOL-LK19-506] 


\section{Auxiliary budget accounts}

Cameroon. Budget annexe de la construction du Port de Douala et du chemin de fer du centre du Cameroun pour l'exercice... Yaounde: Impr. du Gouvernement, 1925,1926. [BnF : NUMP-3511 \& FOL-LK19-506]

Cameroon. Budget annexe de la santé publique et de l'assistance médicale indigène pour l'exercice... Yaounde: Impr. du Gouvernement, 1925, 1926, 1929, 1932. [BnF : NUMP-3511 \& FOL-LK19-506]

Cameroon. Budget annexe de la santé publique. Compte définitif des recettes et des dépenses. Exercice.... Paris: Imprimerie-Librairie Militaire Universelle L. Fournier, 1924, 1931. [BnF: NUMP-3573 \& FOL-LK19-536]

Cameroon. Budget spécial des grands travaux et dépenses sanitaires sur fonds d'emprunt: exercice... Yaounde: Impr. du Gouvernement, 1931-1939. [BnF: NUMP 5167 \& FOL-LK19861]

\section{Madagascar}

\section{Statistical abstracts}

Madagascar, Institut national de la statistique. Annuaire statistique de Madagascar 19381951. Antananarivo: Impr. officielle, 1953. [BnF: LC32-167]. (Contains information on the budget accounts of the provinces in 1931 and from 1938 to 1951).

Budget accounts of Madagascar — definitive

Madagascar. Compte définitif du budget des recettes et des dépenses du service local de Madagascar et Dépendances pour l'exercice... Antananarivo, 1898-1900. [BC: 9.912-2]

Madagascar. Territoire de Madagascar. Budget général. Compte définitif des recettes et des dépenses. Exercice... Antananarivo: Impr. officielle, 1901-1917, 1920, 1922-1923, 1925 1928, 1930-1938, 1940-1945, 1956. [BnF: FOL-LK19-446]

Budget accounts of Madagascar — provisional

Madagascar. Budget des recettes et des dépenses du Service local... Madagascar et dépendances. Antananarivo: Gouvernement général de Madagascar et dépendances, 19001905, 1909-1941, 1943-1946, 1948-1953, 1956-1957. [BnF: NUMP-4474 \& FOL-LK19-428]

Budget accounts of Mayotte and dependencies

Mayotte (Colonie). Comptes définitifs des recettes et des dépenses des services locaux de la Colonie de Mayotte et des protectorats des Comores. Exercice... Paris: Imprimerie nationale, 1898-1906, 1911-1914. [BnF : NUMP-3382 \& FOL-LK19-356]

Mayotte (Colonie). Budget des recettes et des dépenses... Colonie de Mayotte, Service local. Saint-Denis (Reunion Island), then Hell-Ville, then Paris, then Antananarivo, 1881-1898, 1900-1912. [BnF: FOL-LK19-271]

Budget accounts of provinces

Province de Fianarantsoa. Compte définitif du budget provincial de Fianarantsoa. Fianarantsoa, 1949-1952, 1945-1956. [BnF: FOL-LK19-953]

Mahajanga (Province). Province de Majunga. Compte définitif des recettes et des dépenses. Exercice... 1949, 1951-1956. [BnF: FOL-LK19-95] 
Province de Tamatave. Province de Tamatave. Compte définitif. Tamatave. 1949-1956. [BnF: FOL-LK19-951]

Province de Tananarive. Compte définitif du budget provincial de Tananarive. Exercice 1956. [BnF: FOL-LK19-950]

Province de Tuléar. Province de Tuléar. Budget provincial. Compte définitif. Tuléar, 1949, 1951-1956. [BnF: FOL-LK19-949]

Auxiliary accounts

Madagascar. Compte définitif du budget spécial des grands travaux et dépenses sanitaires sur fonds d'emprunt : exercice... Madagascar et dépendances. Antananarivo: Impr. officielle, 1931, 1935-1942. [BnF: FOL-LK19-863]

Madagascar. Budget spécial des grands travaux et dépenses sanitaires sur fonds d'emprunt. Exercice... Antananarivo: Gouvernement général de Madagascar et dépendances, 1931-1942. [BnF: NUMP 5038 \& FOL-LK19-685]

\section{FIDES}

Institut d'Etude du Développement Economique et Social (IEDES). Les investissements publics d'origine locale et d'origine extérieure dans les pays francophones d'Afrique tropicale. 1946-1960. Volume II : Tableaux Statistiques. [BUG: D0342608839]

\section{Post colonial}

Amin, Samir. L'Afrique de l'Ouest bloquée: l'économie politique de la colonisation, 18801970. Paris: Editions de Minuit, 1971.

Comité monétaire de la zone franc. La Zone Franc en ... : Rapport publié par le Secrétariat du Comité monétaire de la zone franc. Paris: Imprimerie nationale, 1953-1995. [BnF: NUMP10930]

Haute-Volta, Direction du plan et des études de développement. Bilan du plan cadre, 19671970. Ouagadougou, 1971. [BnF: MICROFICHE M-15031]

Madagascar, Commissariat général au plan. Rapport sur l'exécution du plan quinquennal 1964-1968. Antananarivo: 1965-1969. [BnF: MICR M-25337]

OECD. OECD development co-operation directorate development assistance committee (DCD-DAC) official development assistance (ODA) data. http://www.oecd.org/dac/financing-sustainable-development/development-finance-data/ (accessed 08/24/2017).

Senegal, Secrétariat d'Etat au plan. Rapport d'évaluation du $3^{e}$ plan quadriennal de développement économique et social, année 1969-1970. Dakar, 1972. [BnF: 4-O3W-553]

Tunisia, Secrétariat d'Etat au plan et aux finances. Annuaire statistique de la Tunisie. Tunis: Institut national de la statistique, 1964-65. [BnF: 4-O3W-35]

\section{POPULATION}

Africapolis. http://www.africapolis.org/

Algeria, Sous-direction des statistiques. Annuaire statistique de l'Algérie. Algiers: Impr. Administrative Emile Pfister, various dates between 1926 and 1960. [BnF: 4-O3W-583] 
Banens, Maks. "Vietnam: a reconstitution of its 20th century population history." In Vietnam Economic History, edited by Jean-Pascal Bassino, Jean-Dominique Giacometti and Konosuke Odaka, 1-45. Tokyo: Hitotsubashi University, 2000.

Bassino, Jean-Pascal. "Preliminary estimates of Vietnam GDP 1800-1970: North-South economic divide in historical perspective". International research workshop on Asian historical statistics database, 7-8 January 2000.

Chandler, Tertius, 1987. Four Thousand Years of Urban Growth: An Historical Census. Lewiston, NY: St. David's University Press.

CICRED (Comité International de Coordination des Recherches Nationales en Démographie). La Population de l'Algérie. Paris: CICRED, 1974a.

CICRED (Comité International de Coordination des Recherches Nationales en Démographie). La Population du Maroc. Paris: CICRED, 1974b.

CICRED (Comité International de Coordination des Recherches Nationales en Démographie). La Population de la Tunisie. Paris: CICRED, 1974c.

Eggiman, Gilbert. La population des villes des tiers mondes, 1500 - 1950 : Afrique, Asie, Amérique latine. Genève : Droz, 1999.

Frankema, Ewout and Morten Jerven. "Writing History backwards or sideways: towards a consensus on African population, 1850-2010". The Economic History Review, 67, no. 40 (2014): 907-931.

France, Ministère de la France d'Outre-mer. Tableau économique et social des Etats et territoires d'Outre-mer à la veille de la mise en place des nouvelles institutions. Paris: Presses universitaires de France, 1959. [BnF: 8-LK9-1398]

Indochine française, Bureau de la statistique générale. Annuaire statistique de l'Indochine. Hanoï: Impr. d’Extrême-Orient, 1927-1949. [BnF: 4-LC32-125]

Great Britain, Colonial Office. Report by H.M. Government in the United Kingdom of Great Britain and Northern Ireland to the Council of the League of Nations on the Administration of the British Cameroons. London: H.M. Stationery Office, 1922-1938. [BnF: 8-NW-79]

Great Britain, Colonial Office. Report by H.M. Government in the United Kingdom to the General Assembly of the United Nations on the Administration of the Cameroons under United Kingdom Trusteeship. London: H.M. Stationery Office, 1949-1959. [BnF: 8NW-79]

INSEE (Institut National de la Statistique et des Etudes Economiques). Annuaire Statistique de la France. Paris: Imprimerie nationale,1961, 1962. [BnF: NUMP-10025]

INSEE (Institut national de la statistique et des études économiques). Annuaire statistique de la France, résumé rétrospectif. Paris, 1966. [BnF: NUMP-10025]

Madagascar, Institut national de la statistique. Annuaire statistique de Madagascar. Vol. 1: 1938-1951. Antananarivo: Impr. officielle, 1953. [BnF: LC32-167]

Morocco, Protectorat de la République française au Maroc, Gouvernement chérifien, Direction générale de l'agriculture, du commerce et de la colonisation, Service du commerce et de l'industrie. Annuaire de Statistique Générale du Maroc. Casablanca: Imp. Réunies de la Vigie Marocaine et du Petit Marocain, 1925-1926, 1928-1939/1944. [BnF: NUMP-14878 \& 4-O3J-343] 
Morocco, Royaume du Maroc, Ministère de l'Economie Nationale, Division de la Coordination Economique et du Plan, Service Central des Statistiques. Tableaux économiques du Maroc, 1915-1959. Rabat, 1960.

Tabutin, Dominique and Bruno Schoumaker. "The Demography of Sub-Saharan Africa from the 1950s to the 2000s [A Survey of Changes and a Statistical Assessment]”. Population, 59, no. 3-4 (2004): 457-555.

Tunisia, Institut national de la statistique. Annuaire statistique de la Tunisie. Tunis: Institut national de la statistique, various dates between 1940 and 1999. [BnF: 4-O3W-35, 8-SG PER U-160 \& MICROFICHE M-25451]

The World Bank. World Development Indicators. https://data.worldbank.org/datacatalog/world-development-indicators , 2017

United Nations. Demographic Yearbook 1960. New York, 1960.

UNHCR (United Nations High Commissioner for Refugees (UNHCR). The State of The World's Refugees 2000: Fifty Years of Humanitarian Action. 2000. http://www.unhcr.org/afr/publications/sowr/4a4c754a9/state-worlds-refugees-2000-fifty-

years-humanitarian-action.html

Vallin, Jacques, et France Meslé. Tables de mortalité françaises pour les XIXe et XXe siècles et projections pour le XXIe siècle. Données statistiques 4. Paris: Institut National d'Études Démographiques, 2001.

\section{PRICES}

\section{General}

The World Bank. World Development Indicators. https://data.worldbank.org/datacatalog/world-development-indicators, 2017.

\section{Metropolitan France}

INSEE. "Les nouveaux indices de prix de détail à Paris.” Supplément au BMS, janvier-mars 1951. 1951.

Toutain, Jean-Claude. « Le produit intérieur brut de la France de 1789 à 1982 », Economie et Sociétés, 21, n5 (1987): 1-237.

Lévy-Leboyer, Maurice and François Bourguignon. L'économie Française au XIXe siècleAnalyse Macroéconomique. Economica, 1985.

Villa, Pierre. "Un siècle de données macroéconomiques.” INSEE-Résultats no. 303-304, April, 1994.

Villa, Pierre. Séries macroéconomiques historiques: méthodologie et analyse économique. Insee Méthodes no. 62-63, March, 1997.

Vincent, André L. A. «Les comptes nationaux », in Alfred Sauvy, Histoire économique de la France entre les deux guerres, tome 3 («Diverse sujets »), chapitre XII pp. 309-343, Paris : Fayard, 1972. 


\section{Algeria}

Retail price index in Algiers, 33 products (1938-1957)

Algeria, Sous-direction des statistiques. Annuaire statistique de l'Algérie. Nouvelle Série. Volume 1 (1939-1947). Table XIII, p. 250. [BnF: LK8-1043 (BIS)]

Algeria, Sous-direction des statistiques. Annuaire statistique de l'Algérie. Nouvelle Série. Volume 9 (1956-57). Table XIV, p. 176. [BnF: LK8-1043 (BIS)]

\section{Morocco}

Retail price index in Casablanca (1914-1959)

Morocco, Royaume du Maroc, Ministère de l'Economie Nationale, Division de la Coordination Economique et du Plan, Service Central des Statistiques. Tableaux économiques du Maroc, 1915-1959. Rabat, 1960. Table 1, p.214.

\section{Tunisia}

Retail price index (1938-1968)

Tunisia, Institut national de la statistique. Annuaire statistique de la Tunisie. Volume 14. 1963. Tunis. Table IV, p. 159. [BnF: MICROFICHE M-25451]

Tunisia, Institut national de la statistique. Annuaire statistique de la Tunisie. Volume 15. 1964 \& 1965. Tunis. Table IV, p. 141. [BnF: MICROFICHE M-25451]

Tunisia, Institut national de la statistique. Annuaire statistique de la Tunisie. Volume 18. 1968. Tunis. Table 10.7, p. 161. [BnF: MICROFICHE M-25451]

\section{Indochina}

Price of white rice in Saigon (1891-1910)

Indochine française, Bureau de la statistique générale. Résumé statistique relatif aux années 1913 à 1940. Hanoi: Impr. d’Extrême-Orient, 1941, p. 43. [BnF: 4-LK10-906 ]

Cost of living index for Europeans in Saigon and in Hanoi (1911-1940)

Indochine française, Bureau de la statistique générale. Résumé statistique relatif aux années 1913 à 1940. Hanoi: Impr. d’Extrême-Orient, 1941, p. 32. [BnF: 4-LK10-906 ]

Consumer price index for blue collars in Saigon (1941-1948)

Bassino, Jean-Pascal. "Preliminary Estimates of Vietnam GDP 1800-1970: North-South Economic Divide in Historical Perspective.” In Constructing a Historical Macroeconomic Database for the Trans-Asian Regions, edited by Konosuke, Odaka, Kyokawa, Yukihiko, and Kuboniwa, Masaaki, 9-41. Tokyo: Institute of Economic Research, Hitotsubashi University, 2000.

Consumer price index for Europeans in Saigon and Hanoi (1949-1954)

Institut national de la statistique et des études économiques (France). Annuaire statistique de la zone franc. Paris, 1958. Table 1, p.159 [BnF: 4-LC25-321] 


\section{Afrique Occidentale Française}

In Afrique Occidentale Française, we use import prices to measure inflation between 1938 and 1944. We track the price evolution of a yearly subsistence basket composed of 195 $\mathrm{kg}$ of flour, 5 liters of oil, $1.3 \mathrm{~kg}$ of sugar, $1.3 \mathrm{~kg}$ of soap and 600 grams of cotton cloth. See Allen (2009) and Frankema and van Waijenburg (2012) for discussions of the methodology of subsistence baskets. Starting in 1945, we rely on CPI computed by the statistical office of AOF.

Import prices of flour, oil, sugar, soap, and cotton (1938-1944)

Afrique occidentale française, Service de la statistique générale. Annuaire statistique de l'Afrique occidentale française. Vol. 4 : 1939-1951. Dakar: Impr. de la Mission. Table IV, p. 264-267. [BnF: 4-LC32-139]

Cost of living index for Europeans in Dakar (1945-1955) and Abidjan (1947-1955)

Afrique occidentale française, Service de la statistique générale. Annuaire statistique de l'Afrique occidentale française. Vol. 5 : 1950-1954. Dakar: Impr. de la Mission. Tables 1-321 and 1-3-22, p. 330-331. [BnF: 4-LC32-139]

Togo

We did not find prices for Togo before 1960 and we use the consumption price index of AOF (see above).

\section{Afrique Equatoriale Française}

Consumption price index for Europeans in Brazzaville (1938-1955)

Afrique équatoriale française. Annuaire Statistique de l'Afrique équatoriale française. Volume 1936-1950. 1951. Table 3, p. 223. [BnF: MFICHE 4-LC32-158 (1, 1936-1950)]

Consumption price index for Europeans in Bangui (1951-1955) and Fort-Lamy (1950-1955)

Afrique équatoriale française, Territoire de l'Oubangui-Chari, Statistique générale. Annuaire statistique de l'Oubangui-Chari. Vol. 1 : 1940-1955. Bangui. Table 2, p. 179 and table 4, p.181. [BnF: MFICHE 4-LC32-182]

\section{Cameroun}

In Cameroun, we use the consumption price index of Brazzaville to infer inflation between 1938 and 1951.

\section{Consumption price index in Douala (1952-1955)}

Institut national de la statistique et des études économiques (France). Annuaire statistique de la zone franc. Paris, 1958. Table 1, p.159. [BnF: 4-LC25-321] 


\section{Madagascar}

Consumption price index for Europeans in Antananarivo (1938-1951)

Institut national de la statistique et de la recherche économique (Madagascar). Annuaire statistique de Madagascar. Vol.1: 1938-1951. Antananarivo: Impr. officielle, 1953. Table 5, p.158. [BnF: LC32-167]

Consumption price index for Europeans in Antananarivo (1952-1955)

Institut national de la statistique et des études économiques (France). Annuaire statistique de la zone franc. Paris, 1958. Table 1, p.159. [BnF: 4-LC25-321]

\section{GROSS DOMESTIC PRODUCT}

Algeria, Service de statistique générale. Tableau de l'économie Algérienne. Algiers: Impr. Baconnier, 1958. [BnF: 16-LC32-174]

Amin, Samir. L'économie du Maghreb. Paris: Editions de Minuit, 1966.

Amin, Samir. L'Afrique de l'Ouest bloquée: l'économie politique de la colonisation, 18801970. Paris: Editions de Minuit, 1971.

France, Direction des Affaires économiques et du Plan du ministère de la France d'outre-mer, Essai de détermination du revenu national des principaux territoires d'outre-mer en 1947 et en 1953. Paris, 1955. [CAOM 1fides/69/530]

Bassino, Jean-Pascal. "Preliminary estimates of Vietnam GDP 1800-1970: North-South economic divide in historical perspective". International research workshop on Asian historical statistics database, 7-8 January 2000.

Zarka, Claude. "L'économie tunisienne à l'heure de la planification impérative." In Annuaire de l'Afrique du Nord, edited by Centre national de la recherche scientifique, 207-241. Paris: Editions du CNRS, 1964.

Maddison, Angus. L'économie mondiale: Statistiques historiques. Paris: OECD, 2003.

The Maddison Project. http://www.ggdc.net/maddison/maddison-project/home.htm

The World Bank. World Development Indicators. https://data.worldbank.org/datacatalog/world-development-indicators , 2017

Toutain, Jean-Claude. « Le produit intérieur brut de la France de 1789 à 1982 », Economie et Sociétés, 21, n5 (1987): 1-237.

Villa, Pierre. Séries macroéconomiques historiques: méthodologie et analyse économique. Insee Méthodes no. 62-63, March, 1997.

Vincent, André L. A. "Les comptes nationaux », in Alfred Sauvy, Histoire économique de la France entre les deux guerres, tome 3 (« Diversakle sujets »), chapitre XII pp. 309-343, Paris : Fayard, 1972.

\section{DEVELOPMENT OUTCOMES, IMPORTS AND EXPORTS}

Afrique équatoriale française. Annuaire Statistique de l'Afrique équatoriale française. Volume 1936-1950. 1951. [BnF: MFICHE 4-LC32-158 (1, 1936-1950)] 
Afrique occidentale française, Service de la statistique générale. Annuaire statistique de l’Afrique occidentale française. Vol. 4 : 1939-1951. Dakar: Impr. de la Mission. [BnF: 4LC32-139]

Indochine française, Bureau de la statistique générale. Annuaire statistique de l'Indochine. Hanoï: Impr. d’Extrême-Orient, 1927-1949. [BnF: 4-LC32-125 \& MICROFILM M-14883]

Algeria. Exposé de la situation en Algérie. Algiers: Impr. Juillet Saint-Lager, 1875-1955. [BnF: 8-LK19-167]

Algeria. Exposé de la situation de l'Algérie par M. le Gouverneur général... Algiers: Impr. Juillet Saint-Lager, 1875-1955. [BnF: NUMP-3212, 8-LK19-167 \& 8-LK19-85]

Algeria, Gouvernement général civil. Statistique générale de l'Algérie. Algiers: Impr. de l'Association ouvrière, various dates between 1867 and 1925. [BnF: LK8-1043]

Algeria, Sous-direction des statistiques. Annuaire statistique de l’Algérie. Algiers: Impr. administrative Emile Pfister, 1926-1937, 1939-1960. [BnF: LK8-1043 (BIS)]

France, Direction de la Statistique Général, then INSEE. Annuaire statistique. Paris : Imprimerie nationale, 1901-1952. [BnF: NUMP-3859, 4-LC25-276]

France, Ministère de la France d'Outre-mer. Tableau économique et social des Etats et territoires d'Outre-mer à la veille de la mise en place des nouvelles institutions. Paris: Presses universitaires de France, 1959. [BnF: 8-LK9-1398]

France, Ministère des Colonies. Rapport à la S.D.N. sur l'administration sous mandat des territoires du Cameroun. Paris, 1921-1938. [BnF: NUMP-3553, FOL-LK19-563]

France, Ministère des Colonies. Rapport annuel du Gouvernement français à l'Assemblée générale des Nations Unies sur l'administration du Cameroun placé sous la tutelle de la France. Paris, 1947-1957. [BnF: NUMP-3553, FOL-LK19-563]

Madagascar, Institut national de la statistique. Annuaire statistique de Madagascar 19381951. Antananarivo: Impr. officielle, 1953. [BnF: LC32-167]

Marseille, Jacques.Empire colonial et capitalisme français. Histoire d'un divorce. Paris: Albin Michel, 1984 [2nd edition 2005].

Morocco, Protectorat de la République française au Maroc, Gouvernement chérifien, Direction générale de l'agriculture, du commerce et de la colonisation, Service du commerce et de l'industrie. Annuaire de Statistique Générale du Maroc. Casablanca: Imp. Réunies de la Vigie Marocaine et du Petit Marocain, 1925-1926, 1928-1939/1944. [BnF: NUMP-14878 \& 4-O3J-343]

Tunisia, Direction des renseignements et des contrôles civils. Statistique générale de la Tunisie. Tunis, 1881-1939. [BnF: NUMP-7491 \& 4-O31-371]

Tunisia, Institut national de la statistique. Annuaire statistique de la Tunisie. Tunis: Institut national de la statistique, various dates between 1940 and 1999. [BnF: 4-O3W-35, 8-SG PER U-160 \& MICROFICHE M-25451]

\section{REFERENCES}

Allen, Robert C. The British Industrial Revolution in Global Perspective. Cambridge: Cambridge University Press, 2009. 
Besley, Timothy, and Torsten Persson. "Why Do Developing Countries Tax So Little?” Journal of Economic Perspectives 28, no. 4 (2014): 99-120.

Domergue, Manuel, Jacob Tatsitsa and Thomas Deltombe. Kamerun! Une guerre cachée aux origines de la Françafrique (1948-1971). Paris: La Découverte, 2011.

Despuech, Jacques. Le trafic des piastres. Paris: Deux rives, 1953.

Frankema, Ewout, and Marlous Van Waijenburg. "Structural Impediments to African Growth? New Evidence from Real Wages in British Africa, 1880-1965.” The Journal of Economic History 72, no. 04 (December 2012): 895-926.

Mahieu, Alban."Les effectifs de l'armée française en Algérie (1954-1962)", in Jauffret J-C, M Vaisse, Militaires et guérilla dans la guerre d'Algérie, Paris : Ed. Complexe, 2001.

Saaidia, Oissila. “L'invention du culte musulman dans l'Algérie coloniale du xixe siècle.” L’Année du Maghreb, no. 14 (2016) : 115-132. 